8. Originator Remarks:

For approval and release.

11. Receiver Remarks:
11A. Design Basel ine Document?

\section{To: (Receiving Organization) Distribution}
5. Proj./Prog./Dept./Div.:
Spent Nuclear Fuel Project
3. From: (Originating organization) SNF Characterization Project/ $2 F 700$
6. Design Authority/ Oesign Agent/Cog. Engr.:
R.B. Baker

[] Yes $[X]$ No
4. Related EDT No.:

N/A

7. Purchase Order No.:

N/A

9. Equip./Component No.: $\mathrm{N} / \mathrm{A}$

10. System/Bldg./Facility: N/A

12. Major Assm. Dig. No.: N/A

13. Permit/Permit Application No.: $N / A$

14. Required Response Date: $N / A$

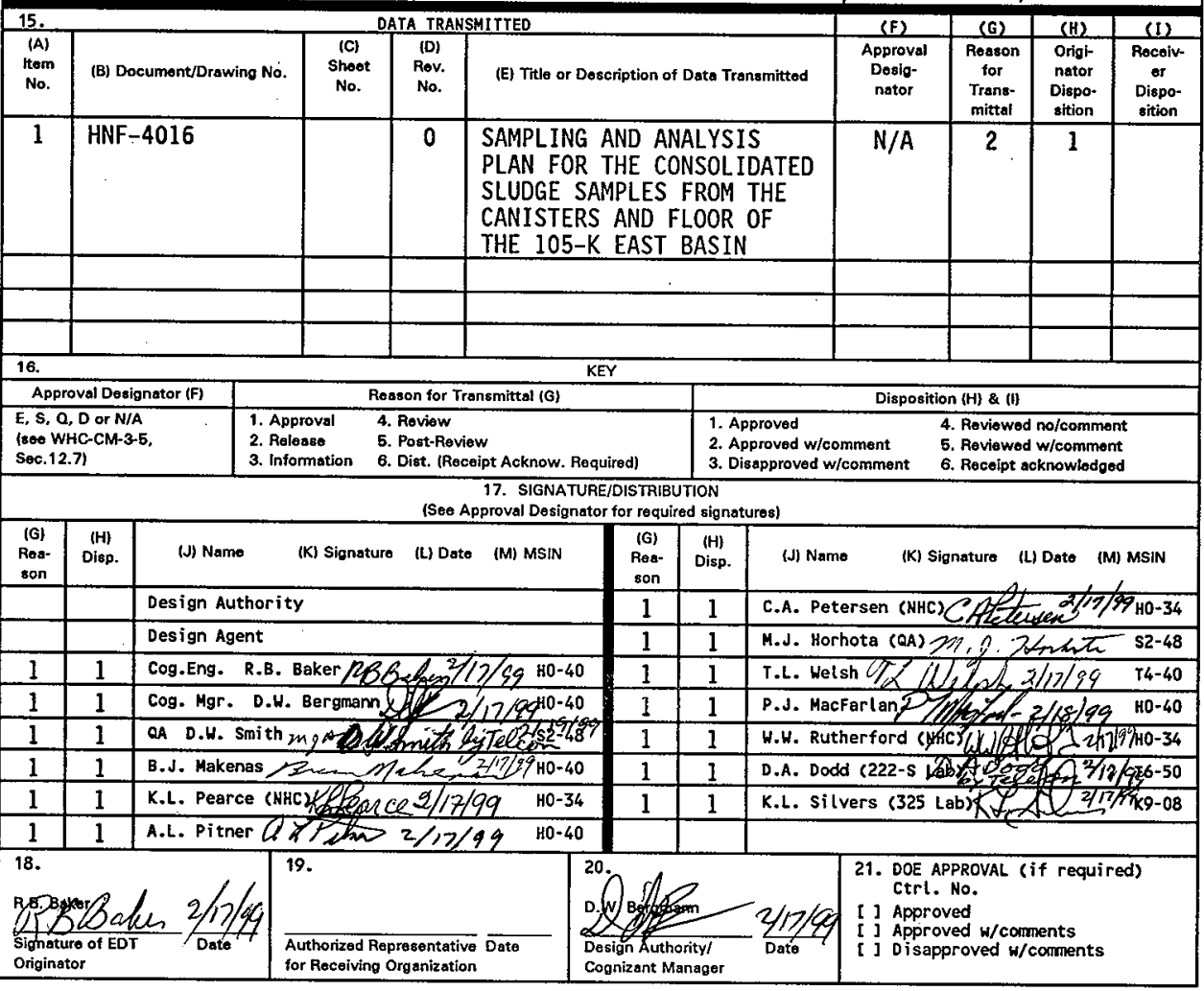




\title{
SAMPLING AND ANALYSIS PLAN FOR THE CONSOLIDATED SLUDGE SAMPLES FROM THE CANISTERS AND FLOOR OF THE 105-K EAST BASIN
}

\author{
R. B. Baker \\ Duke Engineering \& Services Hanford, Inc., Richland, WA 99352 \\ U.S. Department of Energy Contract DE-AC06-96RL13200
}

$\begin{array}{lll}\text { EDT/ECN: } & 626201 & \text { UC: UC 2070 } \\ \text { Org Code: } & 2 \text { F700 } & \text { Charge Code: } 105359 \text {, EH00/Req } 3859 \text { Rel } 13 \text { HN960131 } \\ \text { B\&R Code: } & \text { EW7040000 } & \text { Total Pages: } 105\end{array}$

Key Words: K East Basin, Sludge, Sampling and Analyses, Spent Nuclear Fuel Project

Abstract: This Sampling and Analysis Plan (SAP) provides direction for sampling of fuel canister and floor sludge from the $K$ East Basin to complete the inventory of samples needed for sludge treatment process testing. Sample volumes and sources consider recent reviews made by the sludge treatment subproject. The representative samples will be characterized to the extent needed for the material to be used effectively for testing. Sampling equipment used allows drawing of large volume sludge samples and consolidation of sample material from a number of basin locations into one container. Once filled, the containers will be placed in a cask and transported to Hanford laboratories for recovery and evaluation. Included in the present SAP are the logic for sample location selection, laboratory analysis procedures required, and reporting needed to meet the Data Quality objectives (DQOS) for this initiative.

TRADEMARK DISCLAIMER. Reference herein to any specific commercial product, process, or service by trade name, trademark, manufacturer, or otherwise, does not necessarily constitute or imply its endorsement, recommendation, or favoring by the United States Government or any agency thereof or its contractors or subcontractors.

Printed in the United States of America. To obtain copies of this document, contact: Document Control Services, P.0. Box 950, Mailstop H6-08, Richland WA 99352, Phone (509) 372-2420; Fax (509) 376-4989.
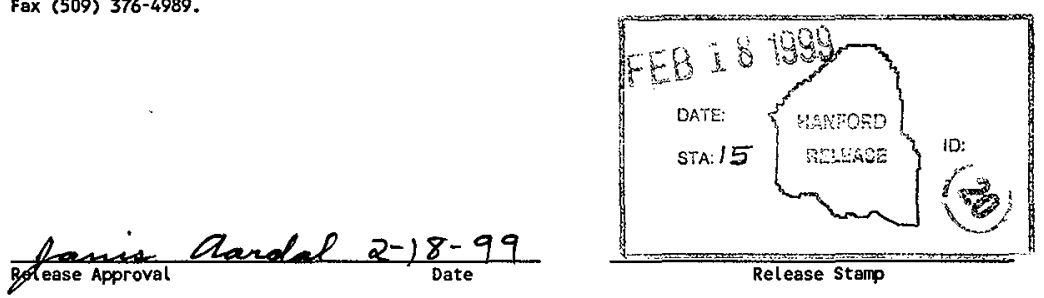
HNF-4016, Rev. 0

\section{SAMPLING AND ANALYSIS PLAN FOR THE CONSOLIDATED SLUDGE SAMPLES}

FROM THE CANISTERS AND FLOOR OF THE 105-K EAST BASIN

R. B. Baker, A. L. Pitner, T. L. Welsh,

B. J. Makenas, and K. L. Pearce

February 1999 
HNF-4016, Rev. 0

\section{CONTENTS}

1.0 SAMPLING OBJECTIVES ....................... 5

1.1 PURPOSE AND BACKGROUND $\ldots \ldots$

1.2 SAMPLING AND ANALYSIS ACTIVITYY OBJECTIVES AND GOALS $: \cdots 7$

$2.0105-K$ EAST BASIN STATUS AND SAMPLING INFORMATION . . . ..... 9

2.1 105-K EAST BASIN SLUDGE CHARACTERIZATION STATUS $\ldots . . . .99$

2.2 SAMPLING INFORMATION $\ldots \ldots \ldots$

2.2.1 Sample Collection and Handling......... 10

2.2 .2 Sample Record Keeping ............ 14

2.2.3 Field Sample Plan Modifications . . . . . . 14

2.2.4 Basis and Locations of Sampling ......... 15

2.2.5 Sample Recovery, Compositing, and Preparation

at Hot Laboratory ............. . 20

3.0 LABORATORY ANALYSIS INSTRUCTIONS ................. 23

3.1 GENERAL . . . . . . . . . . . . . . . . 23

3.2 ANALYSES . . . . . . . . . . 25

4.0 LABORATORY REPORTING REQUIREMENTS ............... 35

4.1 DATA PACKAGING ............................. 35

5.0 FINAL SUMMARY REPORT REQUIREMENTS .............. 37

5.1 STATISTICAL ANALYSIS REQUIREMENTS . . . . . . . . . 37

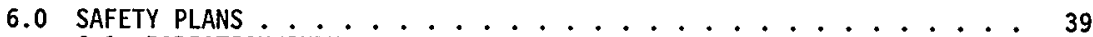

6.1 RADIATION/INDUSTRIAL SAFETY ................. 39

6.2 NUCLEAR CRITICALITY SAFETY . . . . . . . . . 39

7.0 General alara PLAN .................... 41

8.0 QUALITY ASSURANCE AND CONTROL PLAN . . . . . . . . . . . 43

9.0 REFERENCES .............................. 45

APPENDIX A SAMPLING LOCATIONS FOR THE K EAST BASIN

CONSOLIDATED SLUDGE COLLECTION CAMPAIGN . . . . . A-I

APPENDIX B REVIEW OF NEEDS FOR PCB ANALYSES FOR FUTURE

K BASIN SLUDGE ................... B-1 


\section{LIST OF FIGURES}

1. Overview of the Consolidated Sludge Sampling Equipment . . . . . 11

2. Nozzle Area of Extraction Tube . . . . . . . . . . . 13

3. Flow Chart of Sludge Sample Processing and Analyses ....... 24

\section{LIST OF TABLES}

1. Projected Quantities of Sludge Material Needed for Treatment

Process Testing (dry sludge basis) ............ 16

2. Sample Matrix for Consolidated Sampling Campaign ......... 18

3. Sample Location 0ptions .................. 19

4. Proposed Responsible Laboratory and Sample Condition

for Sludge Samples................. 22

5. 105-K East Basin Consolidated Sludge Sample Analyses . . . . . . 26

6. Analytical Requirements for the 105-K East Basin Consolidated Sludge Samples ............... 28 


\section{LIST OF TERMS}

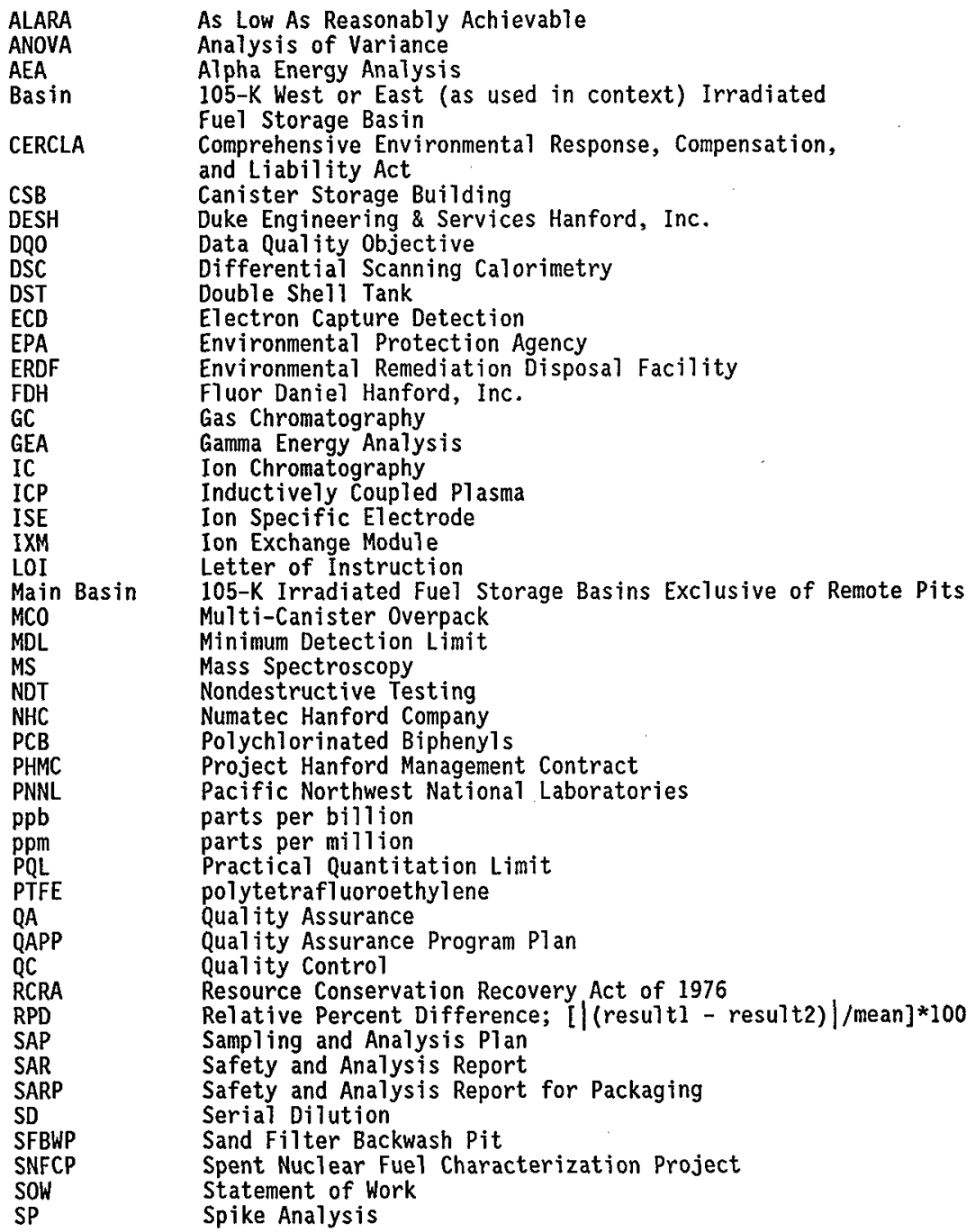


HNF-4016, Rev. 0

\section{LIST OF TERMS (Continued)}

$\begin{array}{ll}\text { SPC } & \text { Statistical Process Control } \\ \text { SVOA } & \text { Semivolatile Organic AnaTysis } \\ \text { TC } & \text { Total Carbon } \\ \text { TCLP } & \text { Toxicity Characterization Leaching Procedure } \\ \text { TGA } & \text { Thermal Gravimetric Analysis } \\ \text { TIC } & \text { Total Inorganic Carbon } \\ \text { TICS } & \text { Tentatively Identified Compounds } \\ \text { TIMS } & \text { Thermal Ionization Mass Spectroscopy } \\ \text { TLD } & \text { Thermoluminescent Dosimeter } \\ \text { TOC } & \text { Total Organic Carbon } \\ \text { TSCA } & \text { Toxic Substances Control Act } \\ \text { TWRS } & \text { Tank Waste Remediation System } \\ \text { VOA } & \text { Volatile Organic Analysis } \\ \text { WHC } & \text { Westinghouse Hanford Company } \\ \text { XRD } & \text { X-Ray Diffraction }\end{array}$


HNF-4016, Rev. 0

\section{SAMPLING AND ANALYSIS PLAN FOR CONSOLIDATED SLUDGE SAMPLES FROM THE CANISTERS AND FLOOR OF THE 105-K EAST BASIN}

\subsection{SAMPLING OBJECTIVES}

\subsection{PURPOSE AND BACKGROUND}

The data quality objectives (DQOS) related to this sludge sampling campaign are provided in Makenas (1999, 1998a). The objectives related to the quantities of sludge material needed for future process testing were reviewed recently by the Spent Nuclear Fuel (SNF) project sludge treatment process subproject and summarized in Petersen (1999). The purpose of the present sampling and analysis plan (SAP) is to define the strategy and the methods that will be used to sample and analyze consolidated sludge samples taken at the 105-K East Basin. These samples will come from: (1) fuel storage canisters and (2) the Main Basin floor where additional quantities of sludge are identified as needed for process treatment testing.

Basic requirements for the sampling were developed by the SNF sTudge treatment process subproject over the past 18 months. Supporting documents include the general subproject DQO (Pearce 1998a), the testing strategy documents (Delegard 1998; Flament 1998a), the recent subproject review (Petersen 1999), and specific sampling DQO documents (Makenas 1999, 1998). The objectives were further confirmed by the independent review team for the initial sludge process flow diagram (PFD) for treatment (Flament 1998b; Fink 1998). This team strongly encouraged continued characterization and analyses of the sludge feed materials to clarify the nominal and bounding cases involved.

Two sampling campaigns were initially planned for FY 1999 to complete all the sludge sampling required for the projects at the $K$ Basins. Initially these campaigns were to be (1) floor and pit sampling and (2) fuel storage canister sampling. Each campaign was to address sludge in both $K$ East and $K$ West Basins. The primary purposes of the sampling were to (1) provide characterization of any significant areas of sludge that were not sampled to-date and (2) provide the balance of characterized sludge required for completion of all the sludge treatment process testing.

In November 1998 a decision was made by the SNF project to take no further sludge samples from the K West Basin (Gerber 1998; Petersen 1998). The cancellation of the $K$ West samples deleted a major portion of material that was required to perform sludge treatment process development and validation testing. In response to this cancellation, a review was made of the remaining sampling plans for $K$ East Basin to determine the most efficient method of obtaining the correct volume of sludge material required to complete the treatment process testing. The conclusions were (Petersen 1999) to:

(1) complete the planned FY 1999 "floor and pit" sludge sampling campaign for the K East Basin (Baker 1998), and (2) modify what was originally termed the 
FY 1999 "canister sludge" sampling campaign, to now be a final sludge sampling campaign where the total volume of sludge required for treatment process testing would be pulled from both the floor and canister locations.

The key to providing the large volume of sludge material required within the constraints of budget and schedule is the "consolidated" sludge sampling equipment, Hecht 1999. This sampler provides the option to continuously draw s]udge sample material into large (10 7iter) underwater shipping containers. A sample container may be moved in the basin to draw sludge from multiple locations (i.e., samples are "consolidated") in the basin. Prior sampling equipment (Baker 1998b) functioned in one mode only, a "single pull"-retaining in the shipping containers all the water and sludge sampled. This is ideal for detailed characterization but not necessary for the current campaign where bulk material for treatment process testing is needed. For this bulk material it was judged acceptable (Petersen 1999; Hecht 1999) to use a very fine filter ( 5 micron) to exhaust excess water back to the basin pool from the sample containers, greatly improving efficiency while maintaining a high quality sample. Acceptance tests of this sampler have shown with simulants there is very little loss of "fines" with the filter system.

Specifically the present SAP contains (1) the plan to acquire the consolidated sludge samples from the floor and canisters of the K East Basin, and (2) the overall requirements for the analytical laboratories to subsample and analyze these samples.

- Sample Acquisition Activities: Based on the DQO documents (Makenas 1999, 1998a) and the review made by the subproject responsible for the treatment of the $K$ Basins sludge (Petersen 1999), a sampling campaign utilizing six sample containers addressing a minimum of about 16 basin locations was planned and is described in this SAP. The sampling will actually use both modes of sampling: (1) the "single pull" system to vacuum a sludge sample into shipping containers (for the instances where maximum representative material is required) and (2) the "consolidated" or "continuous" sampling system, that provides for a continuous suction of sample material and water into a container with the excess water exhausted through a fine filter trapping the sludge sample; this system also allows sampling of two or more similar physical locations into one container ("consolidated" samples). Once the sample containers are filled as desired they will be loaded into a Chem-Nuclear (CNS-13G) cask and transported from the K East Basin to the Hanford 327 Building facility. There they will be unloaded underwater and moved to hot cells for transportation to the neighboring 325 Building laboratory.

- Plan for Detailed Laboratory Analyses of Samples: The second purpose of this SAP is to provide the basic specific requirements for detailed handling and analysis of the sludge samples after completion of initial acquisition activities noted in the previous paragraph. At the laboratory the samples will be recovered from the shipping containers and will be analyzed to establish their composition and character. This will allow these samples to be 
effectively related to past treatment process testing results and integrated into the future test plans. The laboratory requirements in this SAP form the general scope (i.e., specific laboratory procedures, accuracies, etc.) and criteria (i.e., Quality Assurance, reporting, etc.) for the analyses of the sludge samples. Statements of Work (SOW) will be written to the laboratories to supplement this SAP after the samples are recovered from shipping containers and initial observations are complete in the hot cell. The SOWs will provide specific instructions to the laboratories and confirm exactly which samples are to receive particular analyses and any special handling requirements. The final results of the laboratory analyses and their subsequent evaluations plus the bulk sample material made available for treatment process testing, will satisfy the sampling goals of this campaign.

\subsection{SAMPLING AND ANALYSIS ACTIVITY OBJECTIVES AND GOALS}

The DQ0 documents (Makenas 1999, 1998a) for the present activities and the recent sludge treatment project review summarize the objectives and goals of the present sampling effort related to key Spent Nuclear Fuel (SNF) project activities and decisions.

- Objectives: The basic decisions requiring characterized representative sample material for future treatment process development testing activities include: (1) "can one of several proposed treatment schemes convert sludge to a product which is acceptable for disposal at one or more sites (e.g., TWRS DST, Environmental Remediation Disposal Facjlity (ERDF), etc.)?," (2) "does the proposed sludge treatment processes work on a larger scale (i.e., larger than current laboratory tests using several hundred milliliters of sludge)?," and (3) "does fresh sludge (i.e., unoxidized sludge materials versus previously sampled, circa 1995, sludge that was stored, and in most cases dried) influence the proposed sludge treatment process?".

- Sampling Goals: The indicated project decisions have a basic set of sampling goals that are addressed by the present campaign. These include obtaining representative fresh samples of sludge from select multiple regions of the $K$ East Basin. The volumes obtained must be consistent with the sludge treatment process testing needs (Petersen 1999). Local basin samples for use in process testing, will be consolidated or composited either during sampling or at the laboratory to represent the primary basin physical regions required for the process testing. Aliquots of the composites will be submitted for laboratory analyses to determine chemical and isotopic compositions of selected constituents. These analyses will provide estimates of the analyte concentrations considered important to sludge treatment testing and development. Important physical properties of sludge samples will also be obtained from some samples (e.g., settled density, volume, weight, settling time, behavior of selected layers, particle size, rheological properties, etc.). 
Additional attributes may need to be addressed during these laboratory analyses if alternate sludge process treatments (e.g., grinding, direct disposal to solid waste, etc.) are "down-selected" in current studies and prove to be sensitive to parameters other than those of the current chemical treatment process. Optionally (as resources are available), scoping treatment process unit tests may be performed on select siudge samples to assist the sludge treatment process subproject in the ultimate use of the bulk sample material. 
HNF-4016, Rev. 0

\subsection{5-K EAST BASIN STATUS AND SAMPLING INFORMATION}

\subsection{5-K EAST BASIN SLUDGE CHARACTERIZATION STATUS}

The 105-K East Basin was designed and constructed in 1950 to 1951. The purpose of the basin was to receive and store irradiated fuel from the $K$ East reactor. The basin provided the freshly irradiated fuel with cooling and a 150-day period of time to allow short-lived isotopes to decay. The water in the basin provided the workers with shielding from the nuclear radiation resulting from the isotope decay while they sorted and handled the fuel elements underwater.

The K East reactor stopped the irradiation of fuel in 1971. In 1976, the basins started receiving irradiated $N$ Reactor fuel from the 105-N Basin. The fuel was stored in the basin in open twin barreled canisters

(Baker 1995a). A portion of this fuel is still stored in the basin today, and some fuel elements have breached cladding such that significant corrosion of the exposed uranium fuel material may have occurred (see Appendix A). These corrosion products are primarily hydrolyzed metal and deteriorated fuel compounds that precipitate as a flocculent sediment in the bottom of the canister barrels. The canister barrels in some instances also have slotted sides and open bottoms that can leak much of the canister sludge as they are moved in the basin during normal handling (see Figure 1 in Baker 1998b). The basin itself is formed of uncoated concrete, as opposed to $\mathrm{K}$ West Basin where the basin was drained and the concrete sealed prior to the current storage mission. As noted in Appendix A of Baker (1998), the $K$ East Basin contains significant] y more sludge on its floor and in the pits than $K$ West Basin (about $50 \mathrm{~m}^{3} \mathrm{~K}$ East versus $7 \mathrm{~m}^{3} \mathrm{~K}$ West).

The $K$ East Basin main floor and Weasel Pit sludges were characterized in 1995 , based on the analytical results of 20 samples (Makenas 1996c). In addition nine (9) samples of sludge from K East Basin fuel storage canisters. were subsequently taken in 1997 (Makenas 1997). The nine canister samples were taken to compare the mean property measurement values from the canister sludge to those of the floor/pit sludge. The $K$ East Basin floor sludge was also periodically sampled prior to 1995 (Baker 1995b). Overall the analytical results have indicated the floor sludge material to contain predominantly sands, ferric oxides, aluminum oxides, and uranium oxide residuals. The sludge has also been found to contain trace amounts of barium, cadmium, chromium, lead, and samarium. Some sludge samples from the floor, Weasel Pit, and canisters show the presence of polychlorinated biphenyls (PCBs). Canister samples also showed that the sludge generated gas in some of the sample shipping containers and during the settling studies. The canister samples contained high concentrations of fuel or fuel corrosion products (e.g., uranium concentration in dry canister sludge was high as $65 \mathrm{wt} \%$ ). The gas formed in the $K$ East canister sludge was found to be hydrogen with traces of fission gases and tritium. This leads to the conclusion that unreacted uranium metal fuel could be present, however no such metal fuel was detected in the samples analyzed by X-Ray diffraction (XRD). This lack of confirmation may result from there only being comparatively few particles of uranium or that the particles are quickly coated with an oxide layer masking the uranium metal from the XRD analysis. 
The sludge in the 105-K East Basin Sand Filter Backwash Pit (SFBWP) and its transfer channel are sampled periodically by $K$ Basins operations to monitor fissile inventory buildup. A special sampling effort was completed in 1994 related to a safety issue (Bechtold 1994; Baker 1995b).

The most recent overall set of measurements of floor sludge depths in the 105-K East Basin main basin were completed in 1994 and have shown that the basin floor is covered with sludge ranging from a depth of $5 \mathrm{~cm}$ to $19 \mathrm{~cm}$ (Baker 1995a) and that the Weasel Pit is covered with sludge up to a meter or more in depth (Makenas 1996c, see Appendix B, Figure B1). Potential local sources of sludge that could influence the floor sludge characterization were evaluated by the Spent Nuclear Fuel Characterization Project organization (SNFCP) at that time (Baker 1995b). The local sources (besides the environmental sand, insects, etc.) considered were:

- Fuel sludge passing through openings in canisters containing breached fuel elements

- Corrosion of the aluminum canisters

- Sloughing of the unsealed concrete walls that form the basin

- Flaking paint off the fuel storage racks

- Historical activities (e.g., fuel handling, IXM maintenance, etc.) affecting areas near the mouth of the pits (i.e., Weasel Pit, Tech View Pit, Dummy Elevator Pit, North Loadout Pit, and South Loadout Pit).

As noted earlier, detailed sampling and analyses of the floor sludge in the K East Basin main basin and Weasel Pit (Makenas 1996c) agreed with expectations, with the exception of the unexpected identification of PCBs in some of the sludge samples and the quantity of IXM beads found in certain locations.

In FY 1999 a sampling campaign was initiated to obtain additional floor and pit sludge samples in K East Basin. This included areas not previously sampled in the campaign of 1995 . These samples also were to provide sample material required for sludge treatment process testing. [This initial campaign was also supposed to include sampling $K$ West Basin but this was later deleted. This deletion led in-part to the scope of the present K East Basin campaign, see Section 1.1.]

\subsection{SAMPLING INFORMATION}

\subsubsection{Sample Collection and Handling}

The sampling at $K$ East Basin will be conducted such that the operation does not impact the water quality/air emissions. The sampling apparatus is described in Hecht (1999). One set of equipment will be used but it will be used in two different sampling modes, Figure 1. 
Figure 1. Overview of the Consolidated Sludge Sampling Equipment.

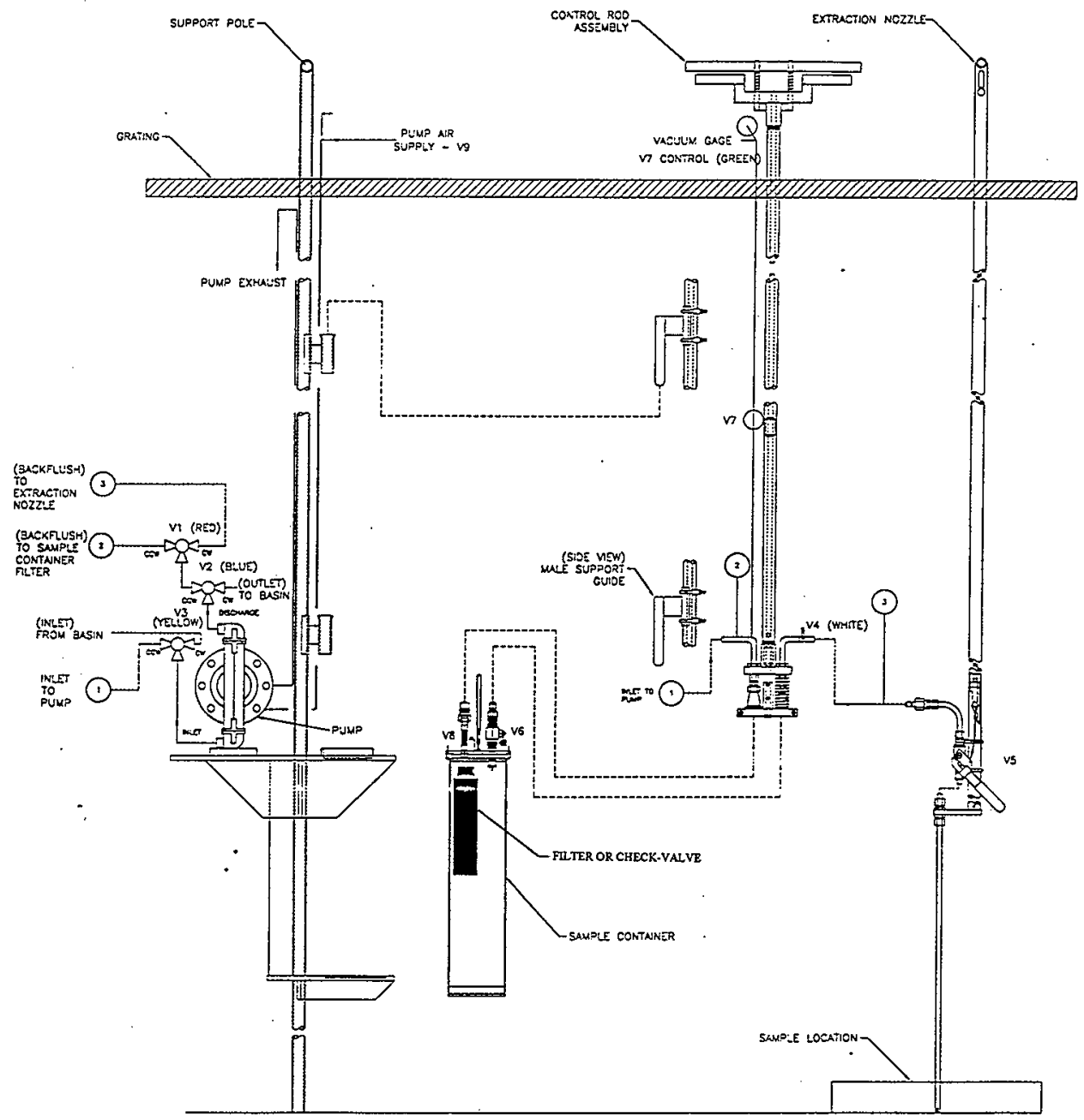


- In the first or "single pull" sampling mode, the sludge will be drawn from the fuel storage canister in a manner similar to that used in the prior campaigns (e.g., Makenas 1998b). A special "vacuum extraction tube," Figure 2, will be lowered into the fuel canisters just above the sludge; then the sludge and water will be vacuumed into the 10 liter sample container until the container is filled (in this mode the sample container receives all water and sludge sampled and retains it). A check-valve is used to stop the sampling as soon as the sample container is full of the water and sludge.

- In the second or the "consolidated or continuous" sampler mode, operation is similar to the first except it is designed to collect s]udge samples from areas where larger sample quantities are required. In this mode the system uses the same vacuum extraction tube but does a continuous draw of material (water and sludge) into the sample container exhausting excess water through a fine (e.g., 5 micron) filter back into the basin pool. Thus, it captures the preponderance of particles greater than 5 microns and a large portion of those 5 microns or less. Full scale acceptance tests with this equipment showed excellent performance with simulants, and very minimal loss of "fines" apparent in the exhausted water (Hecht 1999). It was judged much more important to obtain significant volumes of representative sample material efficiently, than the minor concern for the effects of the filter on physical properties and minor loss of very fine particles. This was further reenforced by the knowledge that base cross-checks against "single pull" sample material will be available for most types of sludge recovered using the consolidated sampler.

While this sampling equipment can be used in two operating modes (i.e., either "single pull" or "consolidated continuous" sampling methods), the equipment in the present text will be referred to as the "consolidated sampler." The application of this equipment at $\mathrm{K}$ Basins is described in the $K$ Basins operations procedures $0 P-43-037 E$ and $O P-07-0132 E$. The consolidated sampler equipment uses the underwater sample containers similar to previous equipment used for sludge sampling (Makenas 1997, 1998). Thus, the basin water provides the shielding for the radioactive samples. The sampler design provides for a flow of water high enough in the extraction tube such that it can collect particles up to a $1 / 4$ inch in diameter, having a density of uranium metal. The nozzle has ports sized to exclude particles greater than $1 / 4$ inch.

Each sludge sample container will be labeled or marked with a unique sample number. The SNFCP organization Test Engineer shall verify to ensure the samples are properly identified and the sample location recorded prior to moving the sample from the K Basins area. The SNFCP organization Test Engineer will ensure that the sample custody during transportation will be tracked at all times by "chain-of-custody" protocol, resulting in documented accountability of the sample. 


\section{HNF-4016, Rev. 0}

Figure 2. Nozzle Area of Extraction Tube.
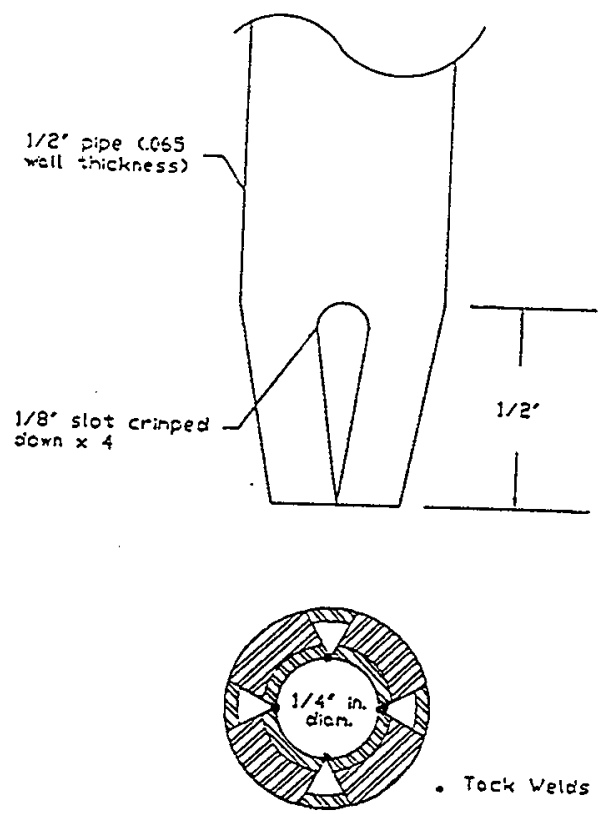
After the sludge samples are collected, they will be loaded underwater into the CNS 1-13G cask per $\mathrm{K}$ Basin procedures. Then the cask will be transported from K Basins to the 327 Building facility, unloaded at the 327 Building facility pool, and from there the sample will be moved to the 325 Building Laboratory using a Hanford 300 Area inter-building cask.

It is the intent of this SAP to ship the samples to the analytical laboratory within one month of when they are collected. If logistics preclude this type shipment from the date of samp1ing, the SNFCP organization Project Coordinator will evaluate the situation to provide applicable storage for the samples. In the basin pools these containers remain in an environment (i.e., temperature, chemistry, etc.) similar to what the sludge would be under normal basin conditions, so the stored samples should maintain their integrity.

Once the sludge samples arrive at the laboratories they will be stored and handled to avoid evaporation as much as possible. Because chemical preservation steps do not make allowance for slurries and would adversely affect the sample ( $\mathrm{pH}$ change), chemical preservation of samples will not be performed. It should be noted that since hydrogen gas generation has occurred in the canister sludge samples, safety precautions are required in sealing any small containers in laboratories and hot cells.

As in the past campaigns, it is planned that the analytical laboratories will dispose of the remains of the sludge and water samples after the analyses and sludge treatment process development tests are completed.

\subsubsection{Sample Record Keeping}

A vital part of the sampling activity is the assurance that all of the information and data associated with each sample are accurate and verifiable. Therefore, all pertinent information and data collected during the sampling, sample breakdown, analyses and reporting will be recorded. The pertinent (e.g., sample locations, sludge depths container numbers, etc.) data to be collected and the corresponding records will be maintained in accordance with the requirements of the sampling procedure (K Basins OP-43-037E and OP-07-0132E), and the QA at the laboratory doing the sample breakdown, analysis and reporting (see Section 8.0). Chain of custody (COC) forms will be used at each step of collection and transfer by field and laboratory personnel (i.e., required in K Basin Project Work Plan, etc). The SoWs for the sampling effort may also provide additional direction on record keeping.

\subsubsection{Field Sample Plan Modifications}

Any modifications to the sludge sampling $\mathrm{plan}$ made in the field must be made/approved by the SNFCP organization Test Engineer and/or SNFCP Project Coordinator and documented. Changes affecting quality related information will include QA approval. 
HNF-4016, Rev, 0

\subsubsection{Basis and Locations of Sampling}

Samples will be taken from locations consistent with the recent review by the sludge treatment subproject (Petersen 1999) and DQOS (Makenas 1999, 1998a). In addition to these general criteria, the selection process also considered: (1) accessibility of the areas by the sampling crew at the basins, (2) possible disruption of the base sludge layers by recent operation and construction activities, and (3) current safety restrictions at the basins. As in past sampling campaigns, a criterion was used to sample in reasonably accessible locations (i.e., sampling through grating slots--no grating removal, sampling around debris--no major debris removal, and sampling around operation obstructions--not removing current restrictions around floor drain valves, etc.). The use of these criteria were judged (Baker 1998c) to have no significant impacts on the quality of the samples with respect to their use. This follows since the sludge within the areas being sampled is expected to be uniformiy deposited across these areas due to the expected dispersion of the material through the pool of water.

Table 1 Column $H$ (from Petersen 1999) defines the basic volumes and source locations of sludge required from the current campaign. This includes 2,800 grams (dry basis) from canisters, 1,750 grams (dry basis) from the Main Basin floor and 1,200 grams (dry basis) of floor sludge with a high percentage of IXM beads. Table 2 (from Petersen 1999) provides an overview of the six samples to be obtained and their objective.

Table 3 indicates the Tocations (cubical numbers in $K$ East Basin) that were selected as potential sampling sites for the six samples of the present campaign. In most instances no more than three general areas were indicated in Table 2 as sources for a particular "consolidated" sample (i.e., floor sludge sample KC-5 is to be collected from each of the three bays in K East Basin). Realistically multiple sites are needed within each region (i.e., each bay) so the test engineers have the latitude to obtain the full volume of sample needed within a region, even if the initial site used does not yield enough material (e.g., it may take two cubical positions in the east bay to obtain the desired volume).

Three sample containers (of the total of six) are to be used to obtain canister sludge samples. The first sample (KC-1), a "single pull" sample will be used as a reference basis for this fresh canister sludge. This sample will contain a full distribution of particle sizes. The second $(\mathrm{KC}-2)$ and third (KC-3) samples provide the large volume samples required for treatment process testing. For these the sampler equipment will be moved from bay to bay in order to obtain a range of material from across the basin. An ultra sound (UT) measurement probe will be used (K Basin Procedure OP-43-037E) to establish "before" and "after" sampling sludge depths (and thus corresponding sludge volumes) in the fuel canister. This method was very successful in the prior K East canister sludge sampling campaign (Makenas 1997).

The remaining three sample containers will be used for the large volume floor sludge samples. Floor and pit sludge sampling started in the K East Basin in December 1998 (Baker 1998) will provide the fresh "single pull" floor sludge samples to be used as baseline fresh sample material if needed to 
HNF-4016, Rev. 0

Table 1. Projected Quantities of Sludge Material Needed for Treatment Process Testing (dry siudge basis).

\begin{tabular}{|c|c|c|c|c|c|c|c|c|c|c|c|c|c|c|c|c|c|c|}
\hline \multirow{4}{*}{ 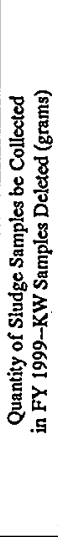 } & \multirow{3}{*}{ 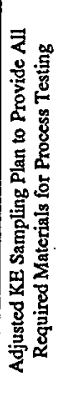 } & 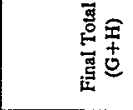 & $\frac{1}{3}$ & $\begin{array}{l}8 \\
\infty \\
\text { r } \\
\text { i }\end{array}$ & 号 & ఫ్స & $\stackrel{8}{\circ}$ & \& & 吕 & ్ㅗ & 0 & 0 & 0 & 0 & 0 & $\begin{array}{l}8 \\
\text { s } \\
\text { N }\end{array}$ & 鰙 & 㝵 \\
\hline & & 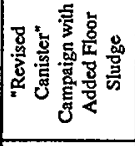 & $\frac{1}{1}$ & 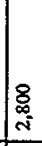 & 号 & 0 & 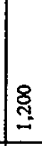 & 0 & 0 & 0 & 0 & 0 & 0 & 0 & 0 & $\begin{array}{l}8 \\
\infty \\
\alpha \\
-1\end{array}$ & ڤू & 究 \\
\hline & & 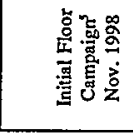 & $\begin{array}{l}1 \\
0 \\
0 \\
1 \\
1\end{array}$ & 0 & ষ্ল & \&్্ & 용 & \& & : & స్తి & 0 & 0 & 0 & 0 & 0 & 0 & $\mid$\begin{tabular}{l}
8 \\
0 \\
\hdashline
\end{tabular} & $\begin{array}{l}8 \\
8 \\
8 \\
-\end{array}$ \\
\hline & & 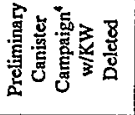 & $\frac{1}{1}$ & $\stackrel{\circ}{\curvearrowleft}$ & 0 & 0 & 0 & 0 & 0 & 0 & 0 & 0 & 0 & 0 & 0 & 号 & 0 & 宫 \\
\hline 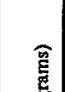 & $\begin{array}{l}\text { 워 } \\
\text { 害 흘 }\end{array}$ & 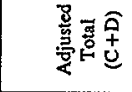 & $\frac{1}{11}$ & 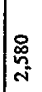 & 总 & ్్ㄱ & 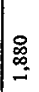 & & $\stackrel{g}{\stackrel{9}{2}}$ & & 0 & & & 0 & & 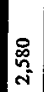 & 疍 & 递 \\
\hline 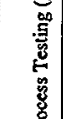 & 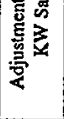 & 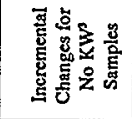 & 年 & $\begin{array}{c} \\
8 \\
8 \\
4 \\
4 \\
4\end{array}$ & $\begin{array}{l}0 \\
0 \\
+\end{array}$ & 0 & 0 & & $\begin{array}{l}8 \\
8 \\
+\end{array}$ & & 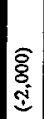 & & & $\frac{8}{7}$ & & $\stackrel{0}{\mathrm{Z}}$ & 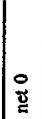 & 음 \\
\hline $\begin{array}{l}5 \\
\text { s. } \\
\frac{8}{8} \\
\frac{8}{2} \\
z \\
0\end{array}$ & 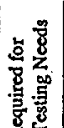 & 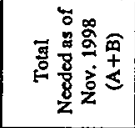 & $e_{i}^{1}$ & 品 & 号 & สิ & 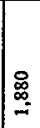 & & : & & ষ্ণ & & & $\stackrel{8}{\stackrel{్}{2}}$ & & দ্ & 总 & 웋 \\
\hline 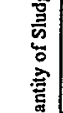 & 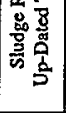 & 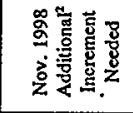 & 要 & 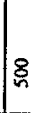 & 8 & 8 & 8 & & 0 & & 0 & & & 0 & & 8 & 8 & i \\
\hline 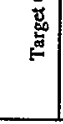 & & 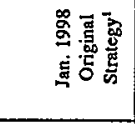 & $\frac{1}{2}$ & 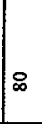 & 貉 & 용 & $\begin{array}{l}8 \\
9 \\
2 \\
-\end{array}$ & & $\stackrel{\circ}{\stackrel{\circ}{\circ}}$ & & $\begin{array}{l}\text { \&్ } \\
\text { N }\end{array}$ & & & ষ্ল్ & & 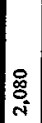 & 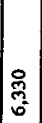 & 站 \\
\hline . & & 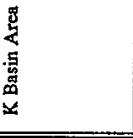 & ह气 & 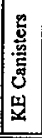 & 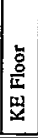 & 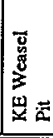 & $\begin{array}{l}\Sigma \\
\vdots \\
\vdots \\
y \\
\mathbf{y}\end{array}$ & 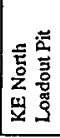 & 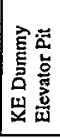 & 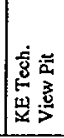 & 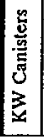 & 总 & 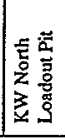 & 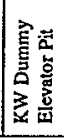 & 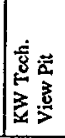 & 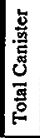 & 亮 & 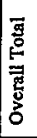 \\
\hline
\end{tabular}


HNF-4016, Rev. 0

Table 1. (Continued)

Notes and Comments:

${ }^{1}$ Estimated quantities of additional sludge from KE Basin required for process development testing--December 1997 estimate (Delegard et al., 1998). Note: these estimated quantities of additional sludge were calculated by subtracting the existing quantities of archived sludge from the total quantities of required sludge for all process development testing.

${ }^{2}$ Based on knowledge of the state of development of the $K$ Basin Sludge Treatment Process as of November 1998, it was determined that an additional $500 \mathrm{~g}$ of sludge should be collected from the KE Floor, KE Floor IXM, KE Weasel Pit, and the KE Canisters. Increased quantities of sludge (i.e., beyond the December 1997 estimates) are projected to be required for: evaluation of alternative sludge treatment technologies; larger scale testing of elutriation and solid/liquid separations; demonstration of sludge transportation within the treatment process; and tank waste compatibility testing (demonstration that treated $K$ Basin sludge is compatible with the waste currently stored in DST AW-105).

${ }^{3}$ On November 9, 1998, a decision was made to cancel all KW Basin sludge sample acquisition activities (Gerber 1998). Consequently, additional sludge from KE Basin will be required to complete testing activities. For example, for canister sludge requirements, $2000 \mathrm{~g}$ has been added to the KE Canister sludge target to compensate for the cancellation of the acquisition of $2000 \mathrm{~g}$ of $\mathrm{KW}$ canister sludge.

"Original campaign planned at beginning of FY 1999 provided five "single pull" samples to obtain a target of $580 \mathrm{~g}$. With this sampling method, the maximum volume in five "single pull" samples would be about $1,400 \mathrm{~g}$.

${ }^{5}$ Baker 1998. 
Table 2. Sample Matrix for Consolidated Sampling Campaign.

\begin{tabular}{|c|c|c|c|}
\hline Sample & $\begin{array}{l}\text { Estimated } \\
\text { Volume of Sludge } \\
\qquad(\mathrm{m} \ell)\end{array}$ & $\begin{array}{l}\text { Estimated Weight of } \\
\text { Sludge for Testing } \\
\text { (g dry) }\end{array}$ & Description \\
\hline $\mathrm{KC}-1$ & 200 to 400 & 250 & $\begin{array}{l}\text { "Single pull" baseline sample taken from a canister barrel for process testing and } \\
\text { characterization: Use a "single pull" sampler method to draw a "fresh" sample of sludge from } \\
\text { a canister barrel with highly damaged fuel. This sample will have material with the most } \\
\text { representative particle size and condition as no filter is used and all particles are retained as } \\
\text { vacuumed into sample container. }\end{array}$ \\
\hline $\mathrm{KC}-2$ & 1000 to 2500 & 1275 & $\begin{array}{l}\text { "Consolidated large volume sample" from at least three canister barrels for process testing: } \\
\text { Use the consolidated sampler equipment to draw a "fresh" consolidated sample from at least } \\
\text { three canister barrels each containing highly damaged fuel and reasonably deep (e.g., greater } \\
\text { than } 3 \text { in.) sludge. If possible draw from one canister barrel in each of the three bays. On a } \\
\text { best effort basis, sample will be targeted at about } 800 \mathrm{~m} \ell \text { from each canister barrel sampled, } \\
\text { resulting in a total volume of about } 2400 \mathrm{~m} \ell \text { of as-settled sludge. The quantity sampled will } \\
\text { be verified in magnitude with before and after sludge depth measurements in the barrels. } \\
\text { All barrels would likely be fabrieated from aluminum as most highly damaged fuel resides in } \\
\text { these. The sample will be checked against Sample \#1 (as most representative material) to } \\
\text { verify consistency of material. }\end{array}$ \\
\hline $\mathrm{KC}-3$ & 1000 to 2500 & 1275 & $\begin{array}{l}\text { "Consolidated large volume sample" from at least three barrels of moderately damaged fuel } \\
\text { for process testing: Same as Sample } \# 2 \text { except the samples would be drawn from at least } \\
\text { three berrels each with a moderate level of fuel damage. Samples may come from barrels } \\
\text { fabricated of either aluminum or stainless steel. : }\end{array}$ \\
\hline $\mathrm{KC}-4$ & 700 to 2500 & 875 & $\begin{array}{l}\text { "Consolidated large volume sample" from floor between at least three pairs of slotted canister } \\
\text { barrels for process testing: Use the consolidated sampler equipment to draw a consolidated } \\
\text { sample from floor area between slotted barrels of at least three canisters, each containing } \\
\text { highly damaged fuel and reasonably deep (e.g., greater than } 3 \text { in.) sludge. If possible one } \\
\text { will be drawn from near a canister in each of the three bays. On a best effort basis each } \\
\text { sample will be targeted at about } 800 \mathrm{~m} \ell \text { each, in a total volume of about } 2400 \mathrm{~m} \ell \text { of as- } \\
\text { settled sludge. A visual perimeter will be used to estimate the volume in each position. This } \\
\text { sample will be validated with Sample KE-13 from the on-going floor sludge sampling [KE-13 } \\
\text { is a single pull sample (Baker } 1998 \mathrm{c} \text { )]. }\end{array}$ \\
\hline $\mathrm{KC}-5$ & 700 to 2500 & 875 & 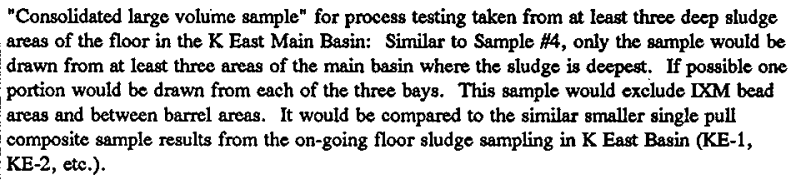 \\
\hline $\mathrm{KC}-6$ & 1000 to 2500 & 1200 & $\begin{array}{l}\text { "Consolidated large volume sample" for process testing from multiple floor areas in the } \\
\mathrm{K} \text { East Basin West Bay where quantities of spilled IXM beads are known to be present: } \\
\text { Multiple locations in cubicles will be sampled in the area near mouth of North Loadout Pit of } \\
\text { the main basin of K East where IXM beads were spilled. The material will be verified by } \\
\text { comparison to the single pull material drawn during the on going K East Basin floor sludge } \\
\text { campaign (i.e., Samples KE-3 and KE-12). }\end{array}$ \\
\hline
\end{tabular}


Table 3. Sample Location Options.

\begin{tabular}{|c|c|c|c|c|}
\hline \multirow{2}{*}{$\begin{array}{l}\text { Sample } \\
\text { No. }\end{array}$} & \multirow[b]{2}{*}{ Type } & \multicolumn{3}{|c|}{ Location Options ${ }^{1}$} \\
\hline & & East Bay & Center Bay & West Bay \\
\hline$K C-1$ & $\begin{array}{l}\text { Canister--Single Pull } \\
\text { Highly Damaged }\end{array}$ & $1236 \mathrm{~W}$ & $4569 \mathrm{E}$ & \\
\hline$K C-2$ & $\begin{array}{l}\text { Canister--Consolidated } \\
\text { High Damage }\end{array}$ & $\begin{array}{l}668 \mathrm{E}, 668 \mathrm{~W} \\
2229 \mathrm{E}\end{array}$ & $\begin{array}{l}2904 \mathrm{~W}, 4564 \mathrm{E} \\
4564 \mathrm{~W}, 4571 \mathrm{E}\end{array}$ & $\begin{array}{l}6068 \mathrm{~W}, 6070 \mathrm{~W}, \\
6071 \mathrm{~W}\end{array}$ \\
\hline $\mathrm{KC}-3$ & $\begin{array}{l}\text { Canister--Consolidated } \\
\text { Moderate Damage }\end{array}$ & $\begin{array}{l}450 \mathrm{E}, 455 \mathrm{~W}, \\
1234 \mathrm{E}, 1252 \mathrm{~W}, \\
2024 \mathrm{E}, 2031 \mathrm{~W}\end{array}$ & $\begin{array}{l}2905 \mathrm{E}, 2943 \mathrm{~W}, \\
3125 \mathrm{~W}, 3727 \mathrm{~W} \\
3937 \mathrm{~W}, 4138 \mathrm{~W}\end{array}$ & $\begin{array}{l}4850 \mathrm{~W}, 4869 \mathrm{E}, \\
5056 \mathrm{E}, 5069 \mathrm{E}, \\
6451 \mathrm{E}, 6452 \mathrm{E}, \\
6757 \mathrm{~W}, 6760 \mathrm{~W}\end{array}$ \\
\hline $\mathrm{KC}-4$ & $\begin{array}{l}\text { Floor--Consolidated } \\
\text { Between Barrels }\end{array}$ & $\begin{array}{l}1168 / 1267 \\
1234 / 1236\end{array}$ & $\begin{array}{l}2952 / 2953 \\
2958 / 2960 \\
4573\end{array}$ & $\begin{array}{l}5465, \\
5445 / 5446 / 5447 \\
\text { (a1) moved) })^{2}\end{array}$ \\
\hline $\mathrm{KC}-5$ & $\begin{array}{l}\text { Floor--Consolidated } \\
\text { Process Testing }\end{array}$ & 2235 & 4535 & 4650 \\
\hline $\mathrm{KC}-6$ & $\begin{array}{l}\text { Floor--Consolidated } \\
\text { IXM Beads }\end{array}$ & & & 6753 to 6761 \\
\hline
\end{tabular}

${ }^{1}$ Locations in $K$ East Basin are indicated by the unique four digit "cubical" numbers, and if applicable also indicate either east ("E") or west ("W") following the four digits referring to the "east" or "west" barrel of the twin barrel canister in this cubical (see Baker 1995; Baker 1998c for summary of K East Basin cubical numbering conventions).

${ }^{2}$ Canisters with damaged fuel and slotted barrels were located in these positions in 1994. Later these were moved to other locations leaving sludge on the floor that would have dropped out the slots and screened holes in the bottom of the barrels. 
compare to these consolidated floor samples. Therefore, all three of the floor sludge samples in this campaign will use the consolidated mode of collection. Sample KC-4 is taken from between slotted canister barrels where there is minimal data on sludge composition, sample $K C-5$ is to be taken to provide sludge from general floor areas, and sample $\mathrm{KC}-6$ is to provide sludge high in IXM bead content. Samples KC-2 through KC-5 will be taken from all three bays if possible to provide a physical representative composite of the basin.

Appendix A provides further detail on the plan and logic for the sampling. This appendix also includes photos of the condition of the fuel at the locations indicated in Table 3.

In addition to the sludge sampling noted here-in during this campaign if possible canister 6070 should be 7 ifted and video taped to confirm if it does or does not have screened bottom holes. This canister has had sludge samples taken in and around it in the past and the status of the barrels have been questioned. The sludge treatment process subproject has requested this (Petersen 1999) to correctly interpret the current data obtained thus far.

\subsubsection{Sample Recovery, Compositing, and Preparation at Hot Laboratory}

Procedure(s) or test instructions for the recovery of the sample material from the shipping containers (i.e., 10 liter sludge containers) and subsequent sample preparation and handling will be prepared by the designated Hanford Laboratory. These procedures will be similar to those used for the K East Basin canister sludge samples (Makenas 1997). The sample preparation and handling procedure will contain the detailed instructions necessary to safely and properly record observations, monitor, settle, decant and subsample (as needed), digest (if necessary), handle, package, and label each sample and its derivatives in the hot cell/hood. The SNFCP organization Project Coordinator will concur with the procedures or test instructions prior to their application.

Samples may be designated either "normal" or "research" after settling. The handling of the "normal" and "research" samples differ in that the research samples will be separated for analyses of individual layers. A "normal" sample will be homogenized and analyses will be performed on the integrated properties. The "research" samples will be separated into major "Tayers" and each layer analyzed. This is necessary for meaningful rheology measurements and is of interest for possible impact of settled layers behaving differently than the mixed mass of the sample (e.g., plutonium concentration). Layers will be identified as was done for the prior $K$ East Basin floor sludge samples--that is a visual identification by color and/or texture of regions of sludge material appearing as stratum after settling studies are completed. Typically two or three layers were found in the K East Basin sludge samples.

At the present time only sample $\mathrm{KC}-1$ is selected as a "research" sample, all other samples are to be handled as "normal" samples. This selection could be revised in subsequent SOWs after the material has gone through settling studies. Only the single pull KC-1 sample was chosen for research type 
analyses because the balance of the samples are large in volume and judged as being better kept intact rather than being separated into layers. Sample $\mathrm{KC}-1$ with its full range of particle sizes will confirm the particle size distribution in fresh high fuel content sludges.

A subsample of throughly mixed material from the "normal" samples may be subjected to seiving and particle size analysis in each case. This will be identified in a SOW after sample settling is complete.

Subsamples for organics analyses and other analyses affected by either drying or acid digestion (TIC, TOC, TC, DSC, IC, XRD, etc.) need to be obtained prior to sample preparation.

In some cases, as specified in subsequent SOWs, the 1iquid portion and the wet sludge should be sampled for the various analyses. Table 4 indicates the condition of the sample material for the various analyses.

It is very important that the analytical laboratories measure and record the evolving densities (i.e., volumes and weights) of the sludge samples (i.e., as-settled, centrifuged, partially dried, dried, etc.). These densities will allow comparisons to past work and the state of sludge as collected. 
HNF-4016, Rev. 0

Table 4. Proposed Responsible Laboratory and Sample Condition for Sludge Samples.

\begin{tabular}{|c|c|c|c|c|}
\hline Analysis ${ }^{1}$ & $\begin{array}{l}\text { Proposed } \\
\text { Laboratory }^{2}\end{array}$ & $\begin{array}{c}\text { Acceptable } \\
\text { to Acid } \\
\text { Digest ? }\end{array}$ & $\begin{array}{l}\text { Acceptable } \\
\text { to Dry? }\end{array}$ & Comments \\
\hline $\begin{array}{l}\text { Rad-Chemistry }{ }^{3} \\
\text { Pu Isotopes } \\
244 \text { Am, } 243 / 244 \mathrm{Cm} \\
\text { U Total } \\
\text { U Isotopes } \\
\text { GEA } \\
\text { Total Alpha } \\
\text { Total Beta } \\
{ }^{9} \mathrm{Tc},{ }^{90} \mathrm{Sr},{ }^{237} \mathrm{~Np} \\
\end{array}$ & $\begin{array}{l}222-S(325) \\
222-S \\
222-S \\
325 / 222-S \\
222-S \\
222-S \\
222-S \\
222-S \\
\end{array}$ & $\begin{array}{l}\text { Yes } \\
\text { Yes } \\
\text { Yes } \\
\text { Yes } \\
\text { Yes } \\
\text { Yes } \\
\text { Yes } \\
\text { Yes } \\
\end{array}$ & $\begin{array}{l}\text { Yes } \\
\text { Yes } \\
\text { Yes } \\
\text { Yes } \\
\text { Yes } \\
\text { Yes } \\
\text { Yes } \\
\text { Yes }\end{array}$ & $\begin{array}{l}{ }^{238} \mathrm{Pu},{ }^{239 / 240} \mathrm{Pu} \\
{ }^{233} \mathrm{U},{ }^{234} \mathrm{U},{ }^{235} \mathrm{U},{ }^{236} \mathrm{U},{ }^{238} \mathrm{U} \\
\mathrm{v}, \mathrm{Cs} \text {, and Eu I sotopes }\end{array}$ \\
\hline $\begin{array}{l}\text { General Chemistry } \\
\text { ICP Metals } \\
\text { IC Ions } \\
\text { TOC/TIC/TC } \\
\text { SVOA/PCB } \\
\text { pH } \\
\end{array}$ & $\begin{array}{l}222-S \\
222-S \\
222-S \\
325 \\
222-S\end{array}$ & $\begin{array}{l}\text { Yes } \\
\text { No } \\
\text { No } \\
\text { No } \\
\text { No } \\
\end{array}$ & $\begin{array}{l}\text { Yes } \\
\text { No } \\
\text { No } \\
\text { No } \\
\text { No } \\
\end{array}$ & Optional \\
\hline $\begin{array}{l}\text { Physical Properties } \\
\text { Gas Generation } \\
\text { Settling Rate } \\
\text { Appearance } \\
\text { Viscosity } \\
\text { Density }(\rho) \\
\text { Settled } \\
\text { Dry Particle } \\
\text { XRD } \\
\text { Pyrophoric Material } \\
\text { Residuals (digest) } \\
\text { Particle Size } \\
\text { Particle Shape } \\
\text { Zeta Potential } \\
\end{array}$ & $\begin{array}{l}325 \\
325 \\
325 \\
325 \\
325 \\
325 \\
325 \\
\\
325 \\
325 \\
325 \\
325 \\
325 \\
\end{array}$ & $\begin{array}{l}\text { No } \\
\text { No } \\
\text { No } \\
\text { No } \\
\text { No } \\
\text { No } \\
\text { No } \\
\\
\text { No } \\
\text { No } \\
\text { No } \\
\text { No } \\
\text { No } \\
\end{array}$ & $\begin{array}{l}\text { No } \\
\text { No } \\
\text { No } \\
\text { No } \\
\text { No } \\
\text { No } \\
\text { No } \\
\\
\text { Yes } \\
\text { Yes } \\
\text { No } \\
\text { No } \\
\text { No } \\
\end{array}$ & Report Full Curves \\
\hline$\frac{\text { Therma] Properties }}{\text { TGA/DSC }}$ & 325 & No & No & Report Full Thermogram \\
\hline Process Testing Samples & $325,222-S$ & No & No & \\
\hline
\end{tabular}

${ }^{1}$ Some sludge materials have PCB levels that may require a TSCA permit for further process testing.

${ }^{2} 222-S$ is the Hanford 222-S Laboratory facility, 325 is the Hanford/PNNL 325 Building Radiochemistry Process Laboratory.

${ }^{3}$ Shipping between laboratories may require 325 Building to run selected radiochemistry

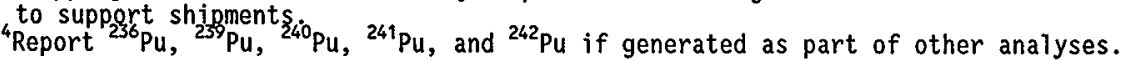


HNF-4016, Rev. 0

\subsection{LABORATORY ANALYSIS INSTRUCTIONS}

\subsection{GENERAL}

Specific additional instructions on processing of each sludge sample in the analytical laboratories may be provided by Statements of Work (SOW) from the SNFCP organization prior to shipment of samples or after the observation of the recovered samples. For shipping subsamples between laboratories, analyses may be requested on sludge samples initially to ascertain properties such as fissile and fission product content for criticality, shielding and accountability (it is expected, however, estimates based on historic data now available will be sufficient).

Each sludge shipping container (10 liter container) will be received by the analytical laboratories. The sludge samples will then be recovered from the shipping containers and prepared for settling studies. Certain samples may be combined to provide further composites, as directed by subsequent soWs. During the settling studies, any observations of gas generation from the sludge material should be immediately noted to the SNFCP organization. If significant, an evaluation will be conducted to determine if gas monitoring is required. High resolution video taping will be made of samples during settling studies and if gas generation is observed.

Selected sludge physical properties (e.g., settling rate, wet and dry, density, etc.) will be obtained prior to any subsampling efforts. Other properties (such as viscosity and particle size/shape) must be determined from aliquots taken prior to any other preparation steps. Prior to heating or caustic fusion for solids, aliquots of both the liquid and the solids will be obtained from the appropriate samples. These aliquots will be used by the laboratories for organic, TIC, TOC, XRD, DSC, TGA, and other analyses sensitive to either drying or acid digestion. An aliquot of the thoroughly stirred dried sludge, of sufficient weight to minimize sample heterogeneity, will then be subjected to caustic fusion.

The laboratory will analyze each al iquot in duplicate or as directed in Section 8.0 of the present SAP or as directed in subsequent SOWs. Each subsample taken from that al iquot must go through separate sample preparation, if sample preparation is required. If a sufficient amount of dried sludge is not available for the caustic fusion step, then analyses for that sample may be limited to higher priority data which will be determined on a case-by-case basis by the SNFCP Project Coordinator. The laboratory should subsequently document the reason for not performing any of the analyses called for in the Sow in the narrative of their data report. An alternative to not performing the analyses is to have $K$ Basin Operations take additional samples for the "other" required analyses. The choice of not performing analyses or requesting additional samples will be at the discretion of the SNFCP organization Project Coordinator.

A flowchart showing the general analysis scheme for the sludge samples in the laboratory is presented in Figure 3 . The analytical tests for the analytical laboratory work are shown in Table 4 . The reason or need for each 
Figure 3. Flow Chart of Sludge Sample Processing and Analyses.

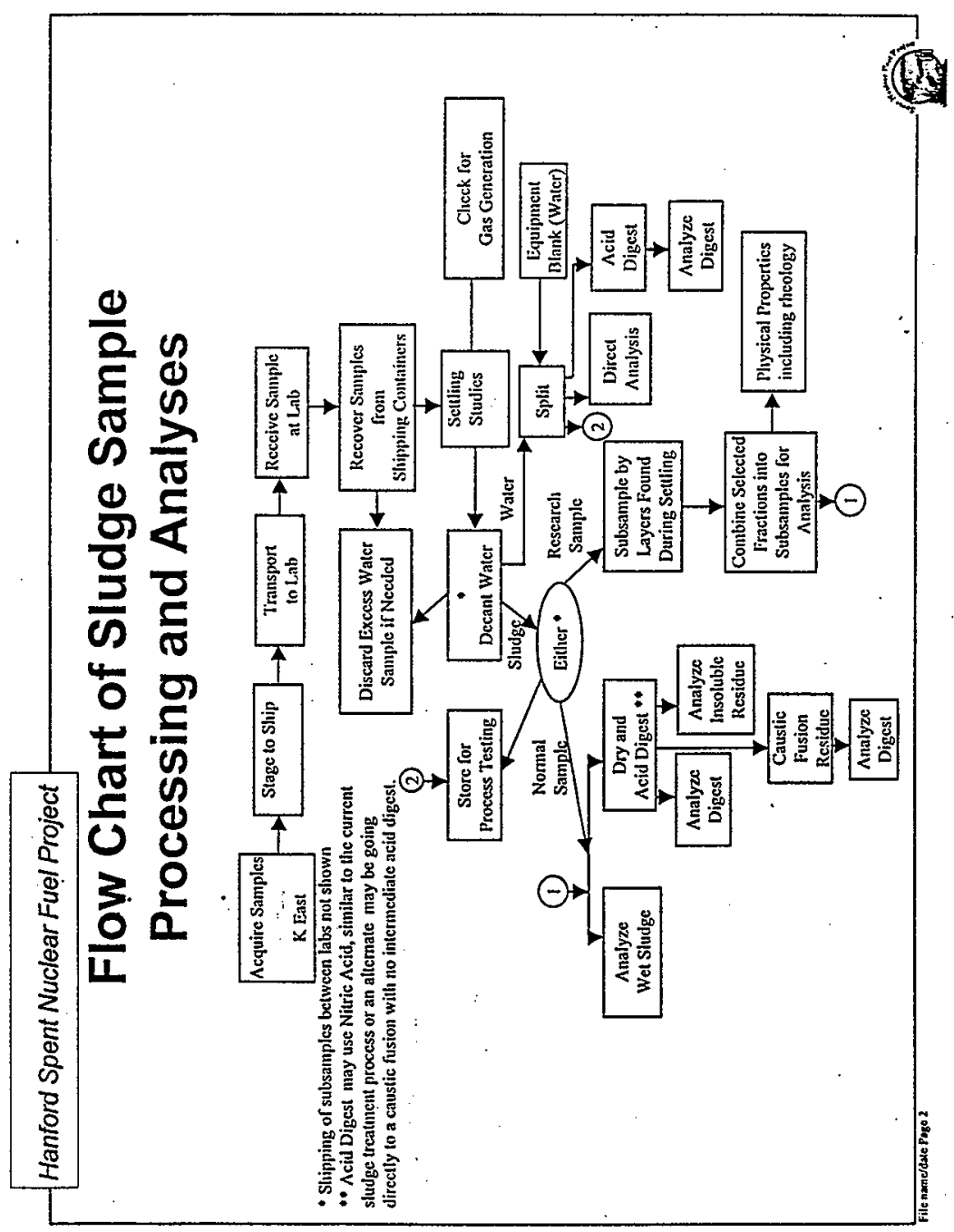


HNF-4016, Rev. 0

of these analyses is defined in the DQO (Makenas 1999, 1998a). In general the samples designated as "normal" will receive all the analyses in Table 5 with the exception of those related to rheology measurements. The "research" samples will be split into samples of the observed layers or strata, and these will generally receive all the analyses in Tables 5 and 6 including rheology measurements (also see Sections 2.3.5 and 3.1).

Note that no analyses for waste designation are called for in the DQO documents (see Section 2.2 of those documents). This follows directly from the assumption made by the SNF Project for $K$ Basin sludge that the waste designation will be made based on "process knowledge." As discussed in the DQO document, pyrophoricity of the sludge is being assessed from the XRD measurements for metallic zirconium, metallic uranium, and uranium hydrides. Exothermic reactions may be evaluated by differential scanning calorimetry (DSC).

A primary objective of this sampling campaign is to provide representative sludge material to the $K$ Basin sludge treatment process development subproject testing activities. Any material not directly used for initial analyses will be kept as close as practical to an "as-collected" state during storage in the hot cells and shipping activities. The material must not be allowed to dry out (avoiding oxidizing materials or causing physical changes such as forming clumps), nor be mixed with non-prototypic materials (e.g., de-ionized water, etc.) or subjected to extremes in environment (i.e, higher than room temperatures, high $\mathrm{pH}$, contact with potentially contaminating surfaces, etc.). The disposition of the sample material will be the subject of a SOW after the samples are obtained and initially observed. This SOW will provide additional direction on storage environment requirements. The actual testing and analyses related to sludge process development testing itself will be covered under separate SOWs from the sludge treatment process subproject. The exception to this is for possible scoping treatment process testing done with the initial samples in direct cooperation with the sludge treatment process subproject. This would be done in order to improve the efficiency of the overall project.

\subsection{ANALYSES}

Table 6 shows the analytes, methods, and the laboratory procedures required for the analysis of the samples. The table also lists the requirements for detection levels, precision, and accuracy of data results. Note that if dilution factors change from what is expected based on factors from the $1995 \mathrm{~K}$ East Basin floor sludge sampling (Miller 1995), the detection levels, precision, and accuracy values shown in Table 6 will have to be re-evaluated. The SNFCP Project Coordinator will be notified of the condition and a decision will be made and documented on how to proceed. One reagent blank will be run if required by the laboratory procedure for each analytical batch. An equipment blank from the $K$ Basin sample collection mockup may be analyzed for each set of new sampling equipment. At least one hot cell blank (if the hot cell is used) will also be analyzed. One method control standard will be run with each batch. A matrix spike will be run per matrix, where applicable, as indicated in Table 6. Also see Section 8.0 on QA requirements. 
HNF-4016, Rev. 0

Table 5. 105-K East Basin Consolidated Sludge Sample Analyses.

\begin{tabular}{|c|c|c|}
\hline Requested Analysis & Analys is Technique & Constituents to be Reported \\
\hline $\begin{array}{l}{ }^{241} \mathrm{Am},{ }^{243 / 244} \mathrm{Cm} \\
\text { Pu-Isotopic }\end{array}$ & $\begin{array}{l}\text { Separation and AEA or } \\
\text { ICP/MS }\end{array}$ & $\begin{array}{l}{ }^{241} \mathrm{Am}{ }^{243 / 244}{ }^{238} \mathrm{Pm}{ }^{24}{ }^{243} \mathrm{Cm} \text { if in suite of } \\
\text { analyses) }\end{array}$ \\
\hline Sr-90 & $\begin{array}{l}\text { Separation and beta } \\
\text { counting }\end{array}$ & ${ }^{90} \mathrm{Sr}$ \\
\hline $\mathrm{Np}-237$ & $\begin{array}{l}\text { Extraction and alpha } \\
\text { counting or ICP/MS }\end{array}$ & ${ }^{237} \mathrm{~Np}$ \\
\hline Total Gamma & GEA & $\begin{array}{l}{ }^{241} \mathrm{Am},{ }^{134} \mathrm{Cs},{ }^{137} \mathrm{Cs},{ }^{60} \mathrm{Co},{ }^{152} \mathrm{Eu},{ }^{154} \mathrm{Eu}, \\
{ }^{155} \mathrm{Eu},{ }^{212} \mathrm{Bi},{ }^{208} \mathrm{Tl},{ }^{125} \mathrm{Sb},{ }^{226} \mathrm{Ra},{ }^{95} \mathrm{Nb}, \\
{ }^{106} \mathrm{Ru} / \mathrm{Rh} \text { and }{ }^{144} \mathrm{Ce} / \mathrm{Pr} \text { and other gamma } \\
\left.\text { emitters in library (e.g., }{ }^{94} \mathrm{Nb}\right)\end{array}$ \\
\hline Gross Alpha & $\begin{array}{l}\text { Gas proportional } \\
\text { counting }\end{array}$ & Detectable alpha emitters \\
\hline Gross Beta & $\begin{array}{l}\text { Gas proportional } \\
\text { counting }\end{array}$ & Detectable beta emitters \\
\hline U Total & $\begin{array}{l}\text { Laser fluorescence or } \\
\text { phosphorescence }\end{array}$ & Total uranium \\
\hline U Isotopics & TIMS or ICP/MS & $\begin{array}{l}{ }^{233} \mathrm{U},{ }^{234} \mathrm{U},{ }^{235} \mathrm{U},{ }^{236} \mathrm{U}{ }^{236}{ }^{238} \mathrm{U} \\
\text { ava (al so report } \\
\left.{ }^{241} \mathrm{Pu} \text { and } \mathrm{Pu} \text {, data on }{ }^{242} \mathrm{Pu}\right)\end{array}$ \\
\hline Metals & ICP/AES & $\begin{array}{l}\mathrm{Al}, \mathrm{Cd}, \mathrm{Sm}, \mathrm{B}, \mathrm{Fe}, \mathrm{Ba}, \mathrm{Cr}, \mathrm{Pb}, \mathrm{Ag}, \\
\mathrm{Be}, \mathrm{Tl}, \mathrm{Zn}, \mathrm{Cu}, \mathrm{Mn}, \mathrm{Mg}, \mathrm{Ca}, \mathrm{Na}, \mathrm{K}, \\
\mathrm{Se}, \mathrm{U}, \mathrm{Zr}, \mathrm{Bi}, \mathrm{P} \text {, and } \mathrm{Ni} \text { ( } \mathrm{Hf}, \mathrm{Sn} \text { if } \\
\text { in current suite of analyses) }\end{array}$ \\
\hline IC Analyses & IC & $\mathrm{PO}_{4}{ }^{3-}, \mathrm{SO}_{4}{ }^{2-}, \mathrm{F}^{-}, \mathrm{Cl}^{-}, \mathrm{Br}^{-}, \mathrm{NO}_{2}^{-}, \mathrm{NO}_{3}^{-}$ \\
\hline Tc-99 & $\begin{array}{l}\text { Solvent extraction } \\
\text { with liquid } \\
\text { scintillation counter }\end{array}$ & ${ }^{99} \mathrm{TC}$ \\
\hline Organics & SVOA & Any TICs found by the analysis, \\
\hline $\begin{array}{l}\text { Endothermic/Exothermic } \\
\text { Reactions (Optional) }\end{array}$ & $\begin{array}{l}\text { DSC/TGA (use TWRS } \\
\text { method with nitrogen } \\
\text { and air cover gas) }\end{array}$ & DSC/TGA include annotated thermogram \\
\hline Settling Rate & $\begin{array}{l}\text { Settling columns and } \\
\text { video camera }\end{array}$ & $\begin{array}{l}\text { Volume settled versus time, video } \\
\text { tape }\end{array}$ \\
\hline
\end{tabular}


HNF-4016, Rev. 0

Table 5. 105-K East Basin Consolidated Sludge Sample Analyses. (Continued)

\begin{tabular}{|c|c|c|}
\hline Requested Analysis & Analysis Technique & Constituents to be Reported \\
\hline $\begin{array}{l}\text { Polychlorinated } \\
\text { Biphenyls (PCB) }\end{array}$ & $\begin{array}{l}\text { PCB as near EPA } \\
\text { methods as reasonabie }\end{array}$ & $\begin{array}{l}\text { PCB concentration in indicated solids } \\
\text { on a dry basis ( } 1 \mathrm{ppm} \text { ) and water } \\
(0.2 \mathrm{ppb}) \text { (Limited analyses-see } \\
\text { Section 3.2) }\end{array}$ \\
\hline $\begin{array}{l}\text { Settled and Dry } \\
\text { Densities }\end{array}$ & $\begin{array}{l}\text { Gravimetric/sample } \\
\text { preparation procedure }\end{array}$ & $\begin{array}{l}\text { Settled and dry density, volume, and } \\
\text { weight }\end{array}$ \\
\hline Residual from Digest & $\begin{array}{l}\text { Gravimetric/sample } \\
\text { preparation procedure }\end{array}$ & $\begin{array}{l}\text { Weight percent of original material } \\
\text { left after digest (wet and dry) }\end{array}$ \\
\hline Residual Analysis & XRD & $\begin{array}{l}\text { Qualitative analysis of any } \\
\text { undigestible residue }\end{array}$ \\
\hline Pyrophoricity & XRD & $\begin{array}{l}\text { Qualitative analysis of the sludge } \\
\text { prior to heating or digestion. } \\
\text { Unreacted metallic uranium and } \\
\text { Zr; unoxidized uranium hydride; } \\
\text { uranium oxide; hydrates of } \mathrm{Al}_{2} \mathrm{O}_{3} \text {, } \\
\mathrm{UO}_{2+} \text { and } \mathrm{FeO}_{\mathrm{x}}\end{array}$ \\
\hline $\begin{array}{l}\text { Particle Size } \\
\text { Distribution }\end{array}$ & $\begin{array}{l}\text { Particle size } \\
\text { analyzer and sieves }\end{array}$ & Size, distribution \\
\hline Particle Shape & $\begin{array}{l}\text { Optical microscopy, } \\
\text { SEM, or TEM }\end{array}$ & Shape \\
\hline Particle Density & $\begin{array}{l}\text { Gas pycnometer/ } \\
\text { calculation }\end{array}$ & Density dry/density wet \\
\hline Viscosity & Viscometer & Viscosity \\
\hline $\mathrm{TIC} / \mathrm{TOC} / \mathrm{TC}$ & $\begin{array}{l}\text { Persulfate oxidation } \\
\text { and coulometry }\end{array}$ & $\operatorname{TIC}\left(\mathrm{CO}_{3}{ }^{2-}\right), \mathrm{TOC}, \mathrm{TC}$ \\
\hline Zeta Potential & Zeta plus instrument & $\mathrm{mV}$ \\
\hline $\begin{array}{l}\text { Gas Generation from } \\
\text { Settlers (Optional) }\end{array}$ & $\begin{array}{l}\text { Capture measured } \\
\text { volume of gas over } \\
\text { specific time and } \\
\text { analyze for } \\
\text { composition }\end{array}$ & $\begin{array}{l}\text { Rate of gas volume generated (as a } \\
\text { function of hours), composition of } \\
\text { gas released, and temperature of } \\
\text { sludge sample }\end{array}$ \\
\hline $\mathrm{pH}$ & pH probe & pH units \\
\hline Cyanide (Optional) & Standard methods & Cyanide concentration \\
\hline
\end{tabular}


HNF-4016, Rev. 0

Table 6. Analytical Requirements for the 105-K East Basin Consolidated Sludge Samples (222-S and 325 Laboratories).

\begin{tabular}{|c|c|c|c|c|c|}
\hline Process & Constituents & Procedure & Required $\mathrm{MDL}^{\dagger}$ & Precision $^{2}$ & Accuracy $^{3}$ \\
\hline \multicolumn{6}{|l|}{ Separation, AEA } \\
\hline & ${ }^{238} \mathrm{Pu}$ & $\begin{array}{l}\text { LA-953-104 } \\
\text { PNL-ALO- } \\
417 / 496 / 422\end{array}$ & $8.0 \mu \mathrm{Ci} / \mathrm{g}$ & $\pm 20 \%$ & - \\
\hline & ${ }^{239 / 240} \mathrm{Pu}$ & \begin{tabular}{|l|} 
LA-953-104 \\
PNL-ALO- \\
$417 / 496 / 422$ \\
\end{tabular} & $3.0 \mu \mathrm{Ci} / \mathrm{g}$ & $\pm 20 \%$ & $\pm 25 \% \mathrm{Sp}$ \\
\hline & $\begin{array}{l}241 \mathrm{Am} \\
{ }^{243} / 244 \\
(242 \\
(2 m \text { if available })\end{array}$ & $\begin{array}{l}\text { LA-953-104 } \\
\text { PNL-ALO- } \\
417 / 496 / 422\end{array}$ & $\begin{array}{l}15.0 \mu \mathrm{Ci} / \mathrm{g} \\
15.0 \mu \mathrm{Ci} / \mathrm{g}\end{array}$ & $\pm 20 \%$ & $\begin{array}{l} \pm 25 \% \text { Sp } \\
\text { Am only }\end{array}$ \\
\hline $\begin{array}{l}\text { Phosphorescence or } \\
\text { Fluorimetric }\end{array}$ & U total & $\begin{array}{l}\text { LA-925-009 } \\
\text { PNL-AL0-445 }\end{array}$ & $10 \mu \mathrm{g} / \mathrm{g}$ & $\pm 20 \%$ & $S P C$ \\
\hline $\begin{array}{l}\text { Thermal Ionization } \\
\text { Mass Spectroscopy } \\
\text { (TIMS) Plasma Mass } \\
\text { Spectroscopy } \\
\text { (ICPMS) }\end{array}$ & $\begin{array}{l}\text { U I sotopics } \\
{ }^{233} \mathrm{U},{ }^{234} \mathrm{U},{ }^{235} \mathrm{U}, \\
{ }^{236} \mathrm{U},{ }^{238} \mathrm{U},{ }^{236} \mathrm{Pu}, \\
{ }^{239} \mathrm{Pu}{ }^{240} \mathrm{Pu},{ }^{241} \mathrm{Pu}, \\
\left.\text { and }{ }^{242} \mathrm{Pu}\right)^{7}\end{array}$ & $\begin{array}{l}\text { PNL-ALO-455 } \\
\text { (TIMS) } \\
\text { LA-506-101 } \\
\text { (ICPMS) }\end{array}$ & $25 \mu \mathrm{g} / \mathrm{g}$ & $\pm 20 \%$ & SPC \\
\hline GEA & & $\begin{array}{l}\text { LA-548-121 } \\
\text { PNL-AL0-450 }\end{array}$ & & & \\
\hline & ${ }^{134} \mathrm{Cs}$ & & $0.20 \mu \mathrm{Ci} / \mathrm{g}$ & $\pm 20 \%$ & -- \\
\hline & ${ }^{137} \mathrm{Cs}$ & & $0.015 \mu \mathrm{Ci} / \mathrm{g}$ & $\pm 20 \%$ & SPC \\
\hline & ${ }^{60} \mathrm{Co}$ & & $0.010 \mu \mathrm{Ci} / \mathrm{g}$ & $\pm 20 \%$ & SPC \\
\hline & ${ }^{241} \mathrm{Am}$ & & $15.0 \mu \mathrm{Ci} / \mathrm{g}$ & $\pm 20 \%$ & $\overline{--}$ \\
\hline & ${ }^{152} \mathrm{Eu}$ & & $1.5 \mu \mathrm{Ci} / \mathrm{g}$ & $\pm 20 \%$ & -- \\
\hline & ${ }^{154} \mathrm{Eu}$ & & $1.5 \mu \mathrm{Ci} / \mathrm{g}$ & $\pm 20 \%$ & -- \\
\hline & ${ }^{155} \mathrm{Eu}$ & & $2.0 \mu \mathrm{Ci} / \mathrm{g}$ & $\pm 20 \%$ & - \\
\hline & ${ }^{212} \mathrm{Bi}$ & & $10.0 \mu \mathrm{Ci} / \mathrm{g}$ & $\pm 20 \%$ & -- \\
\hline & ${ }^{208} \mathrm{TI}$ & & $30.0 \mu \mathrm{Ci} / \mathrm{g}$ & $\pm 20 \%$ & -- \\
\hline
\end{tabular}

1'Required Method Detection Limit (NDL) has been establ ished based on expected concentrations and use of the data, taking into account different capabilities of the laboratories for the equipment and analysis methods in use.

2 Measured sample precision determined by duplicate analyses. The Relative Percent Difference (RPD) between the duplicate analyses is within the specified bounds; e.g., -20\% $<$ RPD $<20 \%$. RPD $=$ [(result 1 - result t2)/mean\}*100.

3

All spike recoveries should be within $\pm 25 \%$. All method standard recoveries should be within statistical process

control (SPC). A serial dilution (SD) will be used to evaluate the method accuracy for some metal analytes.

${ }^{4}$ The sample preparation procedure will provide the calculation used to determine the sludge settled density.

5 Analyze for PCB using same methods as used for $X$ East canister sludge samples or as directed in LOI/sOw. Al compounds should be identified and quantified.

6 If available fron routine analysis, extraordinary measures (purchase of new equipnent) not required.

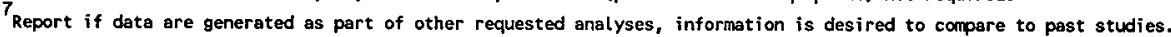

Sp--At least one spike analysis required. 
Table 6. Analytical Requirements for the 105-K East Basin Consolidated Sludge Samples (222-S and 325 Laboratories). (Continued)

\begin{tabular}{|c|c|c|c|c|c|}
\hline Process & Constituents & Procedure & Required $\mathrm{MDL}^{1}$ & Precision ${ }^{2}$ & Accuracy $^{3}$ \\
\hline & ${ }^{125} \mathrm{Sb}$ & & $10.0 \mu \mathrm{Ci} / \mathrm{g}$ & $\pm 20 \%$ & -- \\
\hline & ${ }^{106} \mathrm{Ru} / \mathrm{Rh}$ & & $35.0 \mu \mathrm{Ci} / \mathrm{g}$ & $\pm 20 \%$ & $\overline{--}$ \\
\hline & ${ }^{144} \mathrm{Ce} / \mathrm{Pr}$ & & $25.0 \mu \mathrm{Ci} / \mathrm{g}$ & $\pm 20 \%$ & -- \\
\hline & ${ }^{85} \mathrm{Nb}$ & & $1.0 \mu \mathrm{Ci} / \mathrm{g}$ & $\pm 20 \%$ & -- \\
\hline & ${ }^{226} \mathrm{Ra}$ & & $45.0 \mu \mathrm{Ci} / \mathrm{g}$ & $\pm 20 \%$ & -- \\
\hline Gross Alpha & Total $\alpha$ & $\begin{array}{l}\text { LA-508-101 } \\
\text { PNL-ALO- } \\
420 / 421\end{array}$ & $3.0 \mu \mathrm{Ci} / \mathrm{g}$ & $\pm 20 \%$ & $\pm 25 \% \mathrm{Sp}$ \\
\hline Gross Beta & Total B & $\begin{array}{l}\text { LA-508-101 } \\
\text { PNL-ALO- } \\
430 / 431 \\
\end{array}$ & $0.50 \mu \mathrm{Ci} / \mathrm{g}$ & $\pm 20 \%$ & $\pm 25 \% \mathrm{Sp}$ \\
\hline \multirow[t]{14}{*}{ ICP } & Metals & $\begin{array}{l}\text { LA-505-161 } \\
\text { PNL-AL0-211 }\end{array}$ & & & \\
\hline & A] & & $100 \mu \mathrm{g} / \mathrm{g}$ & $\pm 20 \%$ & $\pm 10 \%$ SD \\
\hline & $\mathrm{Cd}$ & & $15 \mu \mathrm{g} / \mathrm{g}$ & $\pm 20 \%$ & $\pm 25 \% \mathrm{Sp}$ \\
\hline & $\mathrm{sm}$ & & $200 \mu \mathrm{g} / \mathrm{g}$ & $\pm 20 \%$ & $\pm 25 \% \mathrm{Sp}$ \\
\hline & B & & $100 \mu \mathrm{g} / \mathrm{g}$ & $\pm 20 \%$ & $\pm 25 \% \mathrm{Sp}$ \\
\hline & $\mathrm{Fe}$ & & $100 \mu \mathrm{g} / \mathrm{g}$ & $\pm 20 \%$ & $\pm 10 \%$ SD \\
\hline & $\mathrm{Ba}$ & & $100 \mu \mathrm{g} / \mathrm{g}$ & $\pm 20 \%$ & $\pm 25 \% \mathrm{Sp}$ \\
\hline & $\mathrm{Cr}$ & & $20 \mu \mathrm{g} / \mathrm{g}$ & $\pm 20 \%$ & $\pm 25 \% \mathrm{Sp}$ \\
\hline & $\mathrm{Pb}$ & & $200 \mu \mathrm{g} / \mathrm{g}$ & $\pm 20 \%$ & $\pm 25 \% \mathrm{Sp}$ \\
\hline & $\mathrm{Ag}$ & & $20 \mu \mathrm{g} / \mathrm{g}$ & $\pm 20 \%$ & $\pm 25 \% \mathrm{Sp}$ \\
\hline & $\mathrm{Be}$ & & $10 \mu \mathrm{g} / \mathrm{g}$ & $\pm 20 \%$ & $\pm 25 \% \mathrm{Sp}$ \\
\hline & T1 & & $400 \mu \mathrm{g} / \mathrm{g}$ & $\pm 20 \%$ & $\pm 25 \% \mathrm{Sp}$ \\
\hline & $\mathrm{Zn}$ & & $20 \mu \mathrm{g} / \mathrm{g}$ & $\pm 20 \%$ & $\pm 25 \% \mathrm{Sp}$ \\
\hline & $\mathrm{Cu}$ & & $20 \mu \mathrm{g} / \mathrm{g}$ & $\pm 20 \%$ & $\pm 25 \% \mathrm{Sp}$ \\
\hline
\end{tabular}

1

'Required Method Detection Limit (MDL) has been established based on expected concentrations and use of the data, taking into account different capabilities of the laboratories for the equipment and analysis methods in use.

${ }^{2}$ Measured sample precision determined by duplicate analyses. The Relative Percent Difference (RPD) between the duplicate analyses is within the specified bounds; e.g., $-20 \%<R P D<20 \%$. RPD $=[($ result $1-$ result 2$) / m e a n] * 100$.

3

3 All spike recoveries should be within $\pm 25 \%$. All method standard recoveries should be within statistical process control (SPC). A serial dilution (SD) will be used to evaluate the method accuracy for some metal analytes.

4 The sample preparation procedure will provide the calculation used to determine the sludge settled density.

5 Analyze for PCB using same methods as used for $K$ East canister sludge samples or as directed in LO1/SOW. All Aroclor compounds should be identified and quantified.

6f available from routine analysis, extraordinary measures (purchase of new equipment) not required.

7 Report if data are generated as part of other requested analyses, information is desired to corroare to past studies. Sp--At least one spike analys is required. 
Table 6. Analytical Requirements for the 105-K East Basin Consolidated STudge Samples (222-S and 325 Laboratories). (Continued)

\begin{tabular}{|c|c|c|c|c|c|}
\hline Process & Constituents & Procedure & Required $\mathrm{MDL}^{\prime}$ & Precision $^{2}$ & Accuracy ${ }^{3}$ \\
\hline & $k$ & & $1000 \mu \mathrm{g} / \mathrm{g}$ & $\pm 20 \%$ & $\pm 25 \%$ Sp \\
\hline & $\mathrm{Se}$ & & $200 \mu \mathrm{g} / \mathrm{g}$ & $\pm 20 \%$ & $\pm 25 \% \mathrm{Sp}$ \\
\hline & Mn & & $20 \mu \mathrm{g} / \mathrm{g}$ & $\pm 20 \%$ & $\pm 25 \% \mathrm{Sp}$ \\
\hline & $\mathrm{Mg}$ & & $200 \mu \mathrm{g} / \mathrm{g}$ & $\pm 20 \%$ & $\pm 25 \% \mathrm{Sp}$ \\
\hline & $\mathrm{Ca}$ & & $200 \mu \mathrm{g} / \mathrm{g}$ & $\pm 20 \%$ & $\pm 25 \% \mathrm{Sp}$ \\
\hline & $\mathrm{Na}$ & & $200 \mu \mathrm{g} / \mathrm{g}$ & $\pm 20 \%$ & $\pm 25 \% \mathrm{Sp}$ \\
\hline & $2 r$ & & $20 \mu \mathrm{g} / \mathrm{g}$ & $\pm 20 \%$ & $\pm 25 \% \mathrm{Sp}$ \\
\hline & $\mathrm{Ni}$ & & $40 \mu \mathrm{g} / \mathrm{g}$ & $\pm 20 \%$ & $\pm 25 \% \mathrm{Sp}$ \\
\hline & $P$ & & $400 \mu \mathrm{g} / \mathrm{g}$ & $\pm 20 \%$ & $\pm 25 \% \mathrm{Sp}$ \\
\hline & $\mathrm{Bi}$ & & $200 \mu \mathrm{g} / \mathrm{g}$ & $\pm 20 \%$ & $\pm 25 \% \mathrm{Sp}$ \\
\hline 6 & $\mathrm{Hf}$ & & TBD & $\pm 20 \%$ & $\pm 25 \% \mathrm{Sp}$ \\
\hline 6 & $S n$ & & TBD & $\pm 20 \%$ & $\pm 25 \% \mathrm{Sp}$ \\
\hline & $U$ & & $1000 \mu \mathrm{g} / \mathrm{g}$ & $\pm 20 \%$ & $\pm 25 \% \mathrm{sp}$ \\
\hline IC & 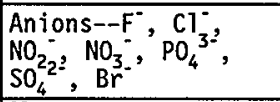 & $\begin{array}{l}\text { LA-533-105 } \\
\text { PNL-ALO-212 }\end{array}$ & $20 \mu \mathrm{g} / \mathrm{m} \ell$ & $\pm 20 \%$ & $\pm 25 \% \mathrm{Sp}$ \\
\hline $\begin{array}{l}\text { Solvent Extraction } \\
\text { with Liquid } \\
\text { Scintillation } \\
\text { Counter }\end{array}$ & ${ }^{99} \mathrm{Tc}$ & LA-438-101 & $0.05 \mu \mathrm{g} / \mathrm{g}$ & $\pm 20 \%$ & SPC \\
\hline $\begin{array}{l}\text { Exothermic/ } \\
\text { Endothermic }\end{array}$ & $\begin{array}{l}\text { DSC (with air and } \\
\text { nitrogen cover gas) }\end{array}$ & $\begin{array}{l}\text { LA-514-114 } \\
\text { PNL-AL0-508 } \\
\text { (or approved } \\
\text { test } \\
\text { instruction) }\end{array}$ & -- & $\pm 20 \%$ & SPC \\
\hline $\begin{array}{l}\text { Drained Solids } \\
\text { (TWRS) }\end{array}$ & Percent water (TGA) & $\begin{array}{l}\text { LA-560-112 } \\
\text { PNL-AL0-508 }\end{array}$ & -- & $\pm 20 \%$ & SPC \\
\hline
\end{tabular}

'Required Method Detection Limit (MDL) has been established based on expected concentrations and use of the data, taking into account different capabilities of the laboratories for the equipment and analys is methods in use.

2 Measured sample precision determined by duplicate analyses. The Relative Percent Difference (RPD) between the duplicate analyses is within the specified bounds; e.g., $-20 \%<$ RPD $<20 \%$. RPD $=$ [(resulti - result 2$) / m e a n] \star 100$.

3

3 All spike recoveries should be within $\pm 25 \%$. All method standard recoveries should be within statistical process control (SPC). A serial dilution (SD) will be used to evaluate the method accuracy for some metal analytes.

${ }^{4}$ The sample preparation procedure will provide the calculation used to determine the sludge settled density.

5 Analyze for PCB using same methods as used for $K$ East canister sludge samples or as directed in LOI/sow. All Aroclor compounds should be identified and quantified.

If available from routine analysis, extraordinary measures (purchase of new equipment) not required.

7 Report if data are generated as part of other requested analyses, information is desired to compare to past studies. Sp--At least one spike analysis required. 
HNF-4016, Rev. 0

Table 6. Analytical Requirements for the 105-K East Basin Consolidated Sludge Samples (222-S and 325 Laboratories). (Continued)

\begin{tabular}{|c|c|c|c|c|c|}
\hline Process & Constituents & Procedure & Required $\mathrm{MDL}^{\top}$ & Precision $^{2}$ & Accuracy ${ }^{3}$ \\
\hline $\begin{array}{l}\text { Hot Persulfate/ } \\
\text { Coulometry }\end{array}$ & $\begin{array}{l}\text { TIC }\left(\mathrm{CO}_{3}^{2-}\right) \text { and } \\
\text { TOC/TIC/TC }\end{array}$ & $\begin{array}{l}\text { LA-342-100 } \\
\text { PNL-AL0-381 }\end{array}$ & $40 \mu \mathrm{g} / \mathrm{g}$ & $\pm 20 \%$ & $\pm 25 \% \mathrm{Sp}$ \\
\hline $\begin{array}{l}\text { Separation and } \\
\text { Beta Counting }\end{array}$ & ${ }^{90} \mathrm{Sr}$ & $\begin{array}{l}\text { LA-220-101 } \\
\text { PNL-ALO- } \\
430 / 431\end{array}$ & $1.0 \mu \mathrm{Ci} / \mathrm{g}$ & $\pm 20 \%$ & $\pm 25 \% \mathrm{Sp}$ \\
\hline $\begin{array}{l}\text { Extraction and } \\
\text { Alpha Count ing }\end{array}$ & ${ }^{237} \mathrm{~Np}$ & $\begin{array}{l}\text { LA-933-141 } \\
\text { PNL-ALO- } \\
415 / 422 \\
\end{array}$ & $5 \mu \mathrm{Ci} / \mathrm{g}$ & $\pm 20 \%$ & $\pm 25 \% \mathrm{Sp}$ \\
\hline $\begin{array}{l}\text { Gravimetric } \\
\text { (before and after } \\
\text { digest, etc.) }\end{array}$ & $\begin{array}{l}\text { Settled and dry } \\
\text { density/volume }\end{array}$ & $\begin{array}{l}\text { Sample } \\
\text { preparation } \\
\text { procedure } \\
\text { LA-519-132 }\end{array}$ & $N / A$ & $N / A$ & N/A \\
\hline $\begin{array}{l}\text { XRD--Prior to } \\
\text { Sample Heating and } \\
\text { Acid Digestion }\end{array}$ & $\begin{array}{l}U \text { (metallic), } \\
\text { Fe hydrates, } \\
\text { Al hydrates, } \\
U \text { hydrides, } \\
U \text { oxides, and } \mathrm{Zr} \\
\text { metal }\end{array}$ & PNL-AL0-268 & $N / A$ & $N / A$ & $N / A$ \\
\hline $\begin{array}{l}\text { XRD--Digestate } \\
\text { Residue }\end{array}$ & $\begin{array}{l}\text { Any identifiable } \\
\text { compounds } \\
\text { (analytes) after } \\
\text { acid digest and } \\
\text { caustic fusion } \\
\end{array}$ & PNL-ALO-268 & N/A & $N / A$ & $N / A$ \\
\hline Settling Rate & $\begin{array}{l}\text { Volume settled } \\
\text { versus time }\end{array}$ & $\begin{array}{l}\text { Sample } \\
\text { preparation } \\
\text { procedure }\end{array}$ & $\mathrm{N} / \mathrm{A}$ & N/A & N/A \\
\hline $\begin{array}{c}\text { Particle Size } \\
\text { 1. Analyzer } \\
\text { 2. Sieving }\end{array}$ & $\begin{array}{l}\text { Particle size } \\
\text { (submicron to } \\
0.25 \text { in.) and } \\
\text { distribution }\end{array}$ & $\begin{array}{ll}\text { 1. } & \text { LT-519-101 } \\
\text { PNL-ALO-530 } \\
\text { 2. } \text { Test } \\
\text { instruction } \\
\text { approved by } \\
\text { SNFCP }\end{array}$ & $N / A$ & $N / A$ & $N / A$ \\
\hline
\end{tabular}

1 Required Method Detection Limit (MDL) has been established based on expected concentrations and use of the data, taking into account different capabilities of the laboratories for the equipment and analysis methods in use.

Measured sample precision determined by duplicate analyses. The Relative Percent Difference (RPO) between the duplicate analyses is within the specified bounds; e.9., $-20 \%<R P D<20 \%$. RPD $=$ [(result1 - result 2$) / m e a n]^{*} 100$.

3

${ }^{3}$ All spike recoveries should be within $\pm 25 \%$. All method standard recoveries should be within statistical process control (SPC). A serial dilution (SD) will be used to evaluate the method accuracy for some metal analytes.

4 The sample preparation procedure will provide the calculation used to determine the sludge settled density.

5 Analyze for PCB using same methods as used for $K$ East canister sludge samples or as directed in LOI/sow. All Aroelor compounds should be identified and quantified.

"If available from routine analysis, extraordinary measures (purchase of new equipment) not required.

7 Report if data are generated as part of other requested analyses, information is desired to compare to past studies. 
Table 6. Analytical Requirements for the 105-K East Basin Consolidated Sludge Samples (222-S and 325 Laboratories). (Continued)

\begin{tabular}{|c|c|c|c|c|c|}
\hline $\begin{array}{l}\text { Process } \\
\end{array}$ & Constituents & Procedure & Required $\mathrm{MDL}^{1}$ & Precision ${ }^{2}$ & Accuracy $^{3}$ \\
\hline Particle Shape & Shape & PNL-AL0-530 & $N / A$ & $N / A$ & $N / A$ \\
\hline Viscometer & Viscosity & $\begin{array}{l}\text { LT-519-115 } \\
\text { PNL-ALO-502 }\end{array}$ & $\mathrm{N} / \mathrm{A}$ & $N / A$ & N/A \\
\hline Organics & SVOA--all TICs & $\begin{array}{l}\text { LA-523-131/406 } \\
\text { PNL-ALO-120/ } \\
344 / 345\end{array}$ & $\begin{array}{l}\text { Report TICs } \\
>10 \mathrm{ppm}\end{array}$ & $\mathrm{N} / \mathrm{A}$ & $N / A$ \\
\hline $\begin{array}{l}\text { Organics - PCBs } \\
\text { (Limited Analyses- } \\
\text { see Section 3.2) }\end{array}$ & $\begin{array}{l}\text { Polychlorinated } \\
\text { biphenyls (PCB) }\end{array}$ & \begin{tabular}{|l} 
PNL-AL0-346 \\
LA-523-136
\end{tabular} & $\begin{array}{l}1 \mathrm{ppm} \\
\text { (solids) } \\
0.2 \mathrm{ppb} \\
\text { (water) }\end{array}$ & $\begin{array}{l}--^{5} \\
--5\end{array}$ & $\begin{array}{l}--^{5} \\
--^{5}\end{array}$ \\
\hline Zeta Potential & Zeta potential & $\begin{array}{l}\text { TWRS-95-5.6a- } \\
2 \text {, Rev. } 0\end{array}$ & TBD & TBD & TBD \\
\hline pH (electrode) & $\mathrm{pH}$ & $\begin{array}{l}\text { LA-212-106 } \\
\text { PNL-AL0-225 }\end{array}$ & $0.1 \mathrm{pH}$ units & $\pm 15 \%$ & SPC \\
\hline $\begin{array}{l}\text { Gas Generation } \\
\text { Rate }\end{array}$ & $\begin{array}{l}\text { Gas volume as rate } \\
\text { of data time (e.g., } \\
\text { hours), volume, and } \\
\text { temperature of } \\
\text { sludge }\end{array}$ & $\begin{array}{l}\text { Test plan } \\
\text { approved by } \\
\text { SNFCP }\end{array}$ & TBD & TBD & TBD \\
\hline $\begin{array}{l}\text { Gas Composition } \\
\text { (optional) }\end{array}$ & $\begin{array}{l}\mathrm{H}, \mathrm{He}, \mathrm{Ar}, \mathrm{N}_{2}, \mathrm{Xe}, \\
\mathrm{Kr}, \text { tritium, and } \\
\text { any other } \\
\text { significant gases }\end{array}$ & PNL-ALO-284 & TBD & TBD & TBD \\
\hline Cyanide (optional) & $\begin{array}{l}\text { LA-695-102 } \\
\text { PNL-AL0-287/289 }\end{array}$ & $\begin{array}{l}\text { LA-695-103 } \\
\text { PNL-AL0- } \\
287 / 289\end{array}$ & $5 \mu \mathrm{g} / \mathrm{g}$ & $\pm 20 \%$ & $\pm 25 \% \mathrm{Sp}$ \\
\hline
\end{tabular}

1 Required Method Detection Limit (MDL) has been established based on expected concentrations and use of the data, taking into account different capabilities of the laborstories for the equipment and analysis methods in use.

Measured sample precision determined by duplicate analyses. The Relative Percent Difference (RPD) between the duplicate analyses is within the specified bounds; e.9., $-20 \%<$ RPD $<20 \%$. RPD $=[($ result1 - result 2$) / m e a n] * 100$. All spike recoveries should be within $\$ 25 \%$. All method standard recoveries should be within statistical process control (SPC). A serial dilution (SD) will be used to evaluate the method accuracy for some metal analytes.

${ }^{4}$ The sample preparation procedure will provide the calculation used to determine the sludge settled density.

5 Analyze for PCB using same methods as used for K East canister sludge samples or as directed in LOL/SOW. All Aroclor compounds should be identified and quantified.

6 If available from routine analysis, extraordinary measures (purchase of new equipment) not required.

7 Report if data are generated as part of other requested analyses, information is cesired to compare to past studies.

Sp- -At least one spike analysis required. 
HNF-4016, Rev. 0

Generally analyses noted in Table 6 may be performed at either the 325 Building laboratory or the 222-S laboratory depending on sludge treatment process subproject logistics and past support in the $K$ Basins sludge characterization efforts (for consistency of data), follow-on test needs, specific laboratory capabilities, sample quantities, schedule, and contractual and HAMTC restrictions. The SOW including the detailed analyses requirements will define which laboratory will perform which analyses. All analyses will be performed consistent with doing work at the Hanford Site and as part of the Project Hanford Management Contract (PHMC).

Additional analyses of the liquid fraction of the sludge samples, beyond those noted in Figure 3 , are potential options to support (1) calculation of maximum theoretical leachate concentration for RCRA heavy metals, and/or

(2) bench scale water/sludge processing tests. These will be addressed in the Sow to the laboratories if they are to be performed. It is acknowledged that due to the potential dose rate of these samples such analyses could require significant additional preparation and costs at the laboratories.

As noted earlier, additional scoping characterization analyses or combined characterization and process development tests, supporting the development and validation of treatment process may also be performed if warranted. If performed, these will be consistent with the DQO and the sludge treatment process subproject objectives in order to utilize limited sample and maximize the use of resources (i.e., funding, laboratory waste disposal, ALARA, etc.). Such analyses will be documented in SOWs to the laboratories.

The analyses of $K$ Basin sludge for PCBs was recently reviewed by the SNF project (Gerber 1999). The direction being followed is provided in Appendix B. For the present samples PCB analyses should only be made if (1) they are part of building a Baseline composite sample for the measurement of PCBs, (2) if it is required for waste disposal at the laboratories (and then on as large a sample as possible), or (3) if directed by a subsequent SOW.

Quality assurance (QA) and quality control (QC) information will conform to those required for a "ful1" data package (as discussed in the following section). The QA/QC standards must conform to Table 6 and/or the applicable analytical procedures. The control standards, spike recoveries, precision between duplicates, hot cell blanks, and equipment blanks need to be within the specified requirements as noted in Table 6 . If the precision between duplicates or the spike recoveries exceed the appropriate criteria there are two options; (1) make one rerun to see if acceptable results are obtained (if acceptable results are not obtained, report the QC failure to SNFCP organization) or (2) report QC failure and suggested actions immediately to SNFCP Program Coordinator for evaluation.

The method detection level (MDL) as used in this document is the detection level which is expected to be achievable by the laboratory to analyze a listed constituent, yet is low enough to detect whether the constituent is present in concentrations significant to resolving data quality objectives (Makenas 1999, 1998a). 
Precision and accuracy requirements for laboratory analytical results specified in this document are based on an assessment of achievable laboratory capabilities, given the complex nature of the samples to be analyzed, their radioactive nature; and the consequent handling, dilution, and analysis methods prescribed. The precision and accuracy statements calculated from the $1995 \mathrm{~K}$ East Basin sludge samples were al so considered in determining the requirements presented in Table 6 . The DQ0s for the present sampling effort (Makenas 1999, 1998a) consolidate and incorporate the various analyses performed to assure that the overall process will produce the analytical results leading to a realization of the sampling objectives. 


\subsection{LABORATORY REPORTING REQUIREMENTS}

The laboratories will be required to submit a final report within a period defined in the SOW from SNFCP Project Coordinator to the laboratories. Opportunities for parallel operations will be developed and schedules will be prepared for laboratory work which will minimize the time actually required. Samples will be processed through the laboratory with the priority required to meet the completion date given in the SOW. The laboratory will be required to submit interim preliminary data reports to the SNFCP Project Coordinator as requested.

The final reports will be internally reviewed by the performing laboratory (as per HNF-SD-SNF-PLN-010, Rev. 1), submitted to the SNFCP Project coordinator for technical review and conform to the requirements for a "full" data package (e.g., similar to Silvers 1997; Miller 1997). If a laboratory uses its own set of internal sample identification numbers in the data reports, a clear cross-reference of these numbers to the original sample identifications will be provided. A narrative that summarizes the results and their quality will also be included, as well as the signature of the individual(s) responsible for the report. The data package will give the duplicate results, all the QC data (laboratory method control standard results, spike recovery results, hot cell blank results, the equipment blank results), deviations from any of the requirements, chain of custody forms, and a narrative. Additional information on the data report content is given in Sections 3.1 and 3.2.

If required data related to dose rates measured on samples to be shipped between the 325 Building and 222-S analytical laboratories, should be transmitted from the shipping laboratory to the receiving laboratory at least 5 working days prior to the actual shipment.

The laboratory performing any analyses of the PCB concentrations in the sludge samples will inform the SNFCP Project Coordinator as soon as definitive data are available. This information will also be transmitted to the other involved laboratories, in case there are any impacts on managing waste. The information will also be provided to K. L. Pearce, NHC, for assessment of impact on sludge treatment process feed stream assumptions.

\subsection{DATA PACKAGING}

Analytical results will be reviewed and processed on a priority basis by the analytical laboratories and other supporting organizations to meet the schedules provided in the SOW. 
HNF-4016, Rev. 0

This page intentionally left blank. 


\subsection{FINAL SUMMARY REPORT REQUIREMENTS}

The completed data packages from the analytical laboratories will be sent to the SNFCP Project Coordinator who will coordinate data review and final summary data report preparation. The data will be reviewed specifically against the criteria set in the DQO document (Makenas 1999, 1998a). The Project Coordinator will ensure the data and reports become a part of the permanent Project Records.

\subsection{STATISTICAL ANALYSIS REQUIREMENTS}

A statistical analysis of the data will be performed as a separate activity from the overall laboratory final data package. This analysis will be reported as part of the final summary evaluation report to be completed by the SNFCP. For each analyte, analys is of variance (ANOVA) techniques will be used to fit a statistical model to the data. This statistical model can be used to:

- Estimate the variability between samples (heterogeneity of the samples)

- Estimate the analytical variability (precision)

- Compute confidence intervals (e.g., $95 \% 90 \%$, etc.) on the mean concentration for each analyte consistent with the requirements of the DQO and sludge treatment process subproject at the time of the report

- Compare present sludge data to past campaigns. 
HNF-4016, Rev. 0

This page intentionaliy left biank. 


\subsection{SAFETY PLANS}

\subsection{RADIATION/INDUSTRIAL SAFETY}

An industrial safety assessment will be performed prior to the start of these activities consistent with the requirements of each performing facility or laboratory. The requirements of HSRCM-1, Hanford Site Radiological Control Manual, shall be adhered to during the performance of sampling activities.

\subsection{NUCLEAR CRITICALITY SAFETY}

A Criticality Safety Assessment will be performed in accordance with requirements of each facility or laboratory involved [e.g., $\mathrm{K}$ Basin Master Work Plan (MWP-99-001)], prior to the start of each activity. The requirements determined by these assessments shall be adhered to during the performance of the sampling activities. 
HNF-4016, Rev. 0

This page intentionally left blank. 
HNF-4016, Rev. 0

\subsection{GENERAL ALARA PLAN}

The sampling procedure for the activities discussed in Section 2.3.1 will take into consideration exposure reduction techniques which will minimize the radiation exposure to the sampling team.

ALARA considerations will be an integrated part of the design effort for the sampling and sampling equipment to minimize personnel exposure. The application of the sampling equipment will be made under specific ALARA plans developed and applied at the K Basins during the campaign. Each laboratory will apply its own review and ALARA plan consistent with operation on the Hanford Site (e.g., the Hanford Site Radiological Control Manual, HSRCM-1). 
HNF-4016, Rev. 0

This page intentionally left blank. 
HNF-4016, Rev. 0

\subsection{QUALITY ASSURANCE AND CONTROL. PLAN}

All sampling, sample handling, sample packaging/shipping, and analytical process activities will be performed in accordance with the requirements of this plan, along with the approved sampling and analysis procedures. Activities at $K$ Basins will be performed consistent with AP-11-014, the SNF project QAPP. The controls identified in this plan have been established to assure the applicable quality assurance requirements of 10CFR830.120 and FDH QAPD (HNF-MP-599, Rev. 2), are satisfied during the performance of this activity. In addition, the analytical laboratory will perform the analyses to its internal quality assurance program plans. The 222-S laboratory will follow WHC-SD-CP-QAPP-016, Qual ity Assurance Program P7 an for Laboratory Analysis and Process Testing. The 325 Building laboratory will follow MCS-033, Quality Assurance Plan for Activities Conducted by the Analytical Chemistry Laboratory.

Method specific quality control (QC) and quality assurance (QA) such as calibrations and blanks are found in the analytical procedures noted in Table 6. Sample quality control (duplicates, spikes, and standards) are identified in Section 3.2 or in the following paragraph. If no criteria are provided in the current document, the performing laboratory shall perform to its quality assurance $p l a n(s)$.

Sample groups will be assigned categories in the SAP or SOW that reflect the number of duplicates and spike analyses that should be run. The categories are:

Category

1 Duplicate analyses will be performed on Samples KC-2, KC-4, and KC-5. One of the samples used for duplicate analyses will be chosen by the laboratory for spike analyses. The balance of the samples will be handled as normal laboratory batches with QC as defined per each 1aboratories internal QA plan.

2 For the one "research" sample the laboratories will run duplicates on layer analyses, no spike analyses are required.

As noted previously, duplicates are repeats of all analyses after completion of settling analyses. Selection of samples within categories should optimize the use of samples with larger volumes for duplicates, allowing the maximum number of requested analyses to be performed for each category.

Care should be taken with water samples processed in conjunction with the sludge analyses (e.g., equipment blanks, etc.), processing them on a best effort basis with criteria similar to that called out in Table 6 , the applicable laboratory procedures, or as called for in the final sow. 
HNF-4016, Rev. 0

This page intentionally left blank. 


\subsection{REFERENCES}

Alderman, C. J., 1997, "Request for Additional Laboratory Tests on Archive $K$ East Basin Floor/Pit Sludge and Canister Sludge, "Internal Memo CJA-97-001 to R. P. Omberg, dated 1997, Duke Engineering \& Services Hanford, Inc., Richland, Washington.

Baker, R. B., 1998a, "Revised Estimates of Sludge Volumes in K East and K West Basins," DESH-9857199, to K. L. Pearce, (included as Appendix A of this SAP), Duke Engineering \& Services Hanford, Inc., Richland, Washington.

Baker, R. B., 1998b, System Design Description for Sampling in K Basin Fuel Storage Canisters, WHC-SD-SNF-SDD-004, Rev. OA, Westinghouse Hanford Company, Richland, Washington.

Baker, R. B., T. L. Welsh, B. J. Makenas, and K. L. Pearce, 1998c, Sampling and Analysis Plan for Sludge Located on the Floor and in the Pits of the 105-K Basins, HNF-3556, Rev. 0, Duke Engineering \& Services Hanford, Inc., Richland, Washington.

Baker, R. B., 1996, "Recommended K West Basin Canisters for Sludge Sampling," Internal Memo to R. P. Omberg, dated 1996, Westinghouse Hanford Company, Richland, Washington.

Baker, R. B., 1995a, Summary Status of K Basin Sludge Characterization, WHC-SD-SNF-TI-006, Rev. O, Westinghouse Hanford Company, Richl and, Washington.

Baker, R. B., 1995b, "Potential Parameters Influencing Floor Sludge Volume or Composition at K East Basin," Internal Memo to T. L. Welsh, (Appendix in Welsh 1995), dated 1995, Westinghouse Hanford Company, Richl and, Washington.

Baker, R. B., 1995c, System Design Description: Sampling Equipment for $K$ Basin Floor Sludge, WHC-SD-SNF-SDD-003, Rev. OA, Westinghouse Hanford Company, Richland, Washington.

Bechtold, D. B., 1994, Report of Laboratory Test P7an for Analysis of KE Basin Backwash Pit Samples, WHC-SD-NR-TRP-021, Rev. 0, Westinghouse Hanford Company, Richland, Washington.

Bechtold, D. B., 1993, Laboratory Test Plan for Analysis of KE Basin Backwash Pit Samples, WHC-SD-NR-TP-023, Rev. 1, Westinghouse Hanford Company, Richland, Washington.

Bridges, A. E., 1996, "Instructions for Cleaning K Basin Canister Sludge Sample Containers, "Internal Memo to D. L. Edwards and K. J. Young, dated 1996, Westinghouse Hanford Company, Richland, Washington. 
HNF-4016, Rev. 0

\subsection{REFERENCES (Continued)}

Qelegard, C. H., et a1., 1998, K Basin S7udge Materials Treatment Testing Strategy, HNF-1926, Rev. O, Pacific Northwest National Laboratory, Richland, Washington.

Dodd, E. N. Jr., 1995, 105-KW Sandfilter Backwash Pit Sludge Volume Characterization, WHC-SD-SNF-TI-010, Rev. 0, Westinghouse Hanford Company, Richland, Washington.

Fink, S. D., et a1., 1998, S7udge Treatment System Project Independent Review Team Report: Process Flow Review, Numatec Hanford Corporation, Richland, Washington.

Flament, T. A., 1998a, Testing Strategy to Support the Development of K Basin Sludge Treatment Process, HNF-2574, Rev. 0, Numatec Hanford Corporation, Richl and, Washington.

Flament, T. A., 1998b, SNF Project Sludge Treatment System Process Flow Diagram, H-1-81170, EDT 625270, Numatec Hanford Corporation, Richland, Washington.

Fowler, K. D., 1995a, Data Quality Objectives for Waste Tank Farms Compatibility Program, WHC-SD-WM-DQO-001, Rev. 1, Westinghouse Hanford Company, Richland, Washington.

Fowler, K. D., 1995b, Tank Farm Waste Transfer Compatibility Program, WHC-SD-WM-OCO-015, Rev. OA, Westinghouse Hanford Company, Richland, Washington.

Hecht, S. L., 1999, System Description for the Consolidated Sludge Sampling System for K Basins Floor and Fuel Canisters, HNF-3971, Rev. 0, Duke Engineering \& Services Hanford, Inc., Richland, Washington.

Gerber, E. W., 1998, "Cancellation of K West Basin Sludge Sampling," SNFP Memo 98-SNF/EWG-004 to D. W. Bergmann, dated December 15, 1998, Duke Engineering \& Services Hanford, Inc., Richland, Washington.

HSRCM-1, Hanford Site Radiological Control Manual, Westinghouse, Hanford Company, Richland, Washington.

Maassen, D. P., and N. R. Roe, 1997, Floor Sludge Depths and Volume of the 105-K Hest Basin, HNF-SD-SNF-TI-054, Rev. 0, Duke Engineering \& Services Hanford, Inc., Richland, Washington.

Makenas, B. J., 1999, Data Quality Objectives for Sampling for K East Basin Canister S7udge Sampling, WHC-SD-SNF-DQ0-008, Rev. OA, Duke Engineering \& Services Hanford, Inc., Richland, Washington.

Makenas, B. J., 1998a, Data Quality Objectives for Sampling of S7udge from the $K$ West and $K$ East Basin Floor and from Other Basin Areas, HNF-2033, Rev. 0, Duke Engineering \& Services Hanford, Inc., Richland, Washington. 


\subsection{REFERENCES (Continued)}

Makenas, B. J., et al., 1998b, Analysis of Sludge from $K$ West Basin Canisters, HNF-1728, Rev. 0, Duke Engineering \& Services Hanford, Inc., Richland, Washington.

Makenas, B. J., et aI., 1997, Analysis of S7udge from the $K$ East Basin Fuel Canisters, HNF-1201 Rev. 0, Duke Engineering \& Services Hanford, Inc. Richland, Washington.

Makenas, B. J., Pearce, K. L., and Baker, R. B., 1996a, Data Quality Objectives for $K$ West Basin Canister Sludge Sampling, WHC-SD-SNF-DQ0-012, Rev. 0, Westinghouse Hanford Company, Richland, Washington.

Makenas, B. J., 1996b, Canister Choices for Sampling of Fuel and Sludge from $K$ West Basin Canisters (Second Characterization Campaign), HNF-SD-SNF-SM-006, Rev. 0, Duke Engineering and Services Hanford, Inc., Richl and, Washington.

Makenas, B. J., et al., 1996c, Analysis of Sludge from the $K$ East Basin and Wease7 Pit, WHC-SP-1182, Westinghouse Hanford Company, Richland, Washington.

Meznarich, H. K., 1998, Quality Assurance Program P7an for Laboratory Analysis and Process Testing, WHC-SD-CP-QAPP-016, Rev. 3A, Westinghouse Hanford Company, Richland, Washington.

Miller, G. L., 1997, Chemical and Radiochemical Characterization of 105-K East Basin Canister sludge, HNF-SD-WM-DP-228, Rev. 0A, Rust Federal Services of Hanford, Inc., Richland, Washington.

Miller, G. L., 1996, Final Chemical and Radiochemical Analytical Report of 105-K East Basin S7udge, WHC-SD-SNF-DP-004, Rev. 1D, Westinghouse Hanford Company, Richland, Washington.

Miller, G. L., 1995, Interim Chemical and Radiochemical Analytical Report of 105-K East Basin Sludge, WHC-SD-SNF-DP-004, Rev. 0, Westinghouse Hanford Company, Richland, Washington.

Packer, M. J., 1998, K Basins Sludge Inventory Composition, HNF-SD-SNF-TI-053, Rev. 0, Duke Engineering \& Services Hanford, Inc., Richland, Washington.

Pearce, K. L., et a1., 1998a, Data Quality Objectives for $K$ Basin Conditioning System Laboratory Testing, HNF-1927, Rev. 1, Duke Engineering \& Services Hanford, Inc., Richland, Washington.

Pearce, K. L., et a1., 1998b, 105-K Basin Material Design Basis Feed Description for Spent Nuclear Fuel Project Facilities, Volume 2, Sludge, HNF-SD-SNF-TI-009, Rev. 2, Numatec Hanford Corporation, Richland, Washington. 


\subsection{REFERENCES (Continued)}

Petersen, C. A., et al., 1999, Revised Sampling Campaigns to Provide S7udge for Treatment Process Testing, HNF-4015, Rev. 0, Numatec Hanford Corporation, Richland, Washington.

Petersen, C. A., 1998, "Meeting Minutes: K West (KW) Basin Sludge Sampling," to Distribution, dated November 9, 1998, ???, Richland, Washington.

Pitner, A. L., 1997, Visual Examinations of $K$ West Fuel Elements, HNF-SD-SNF-TI-046, Rev. 0, Duke Engineering and Services Hanford, Inc., Richland, Washington.

Pitner, A. L., 1996, Test Plan for $K$ East Visual and Ultrasound Survey of Candidate Canisters for Fuel and Sludge Characterization, WHC-SD-SNF-TP-024, Rev. O, Westinghouse Hanford Company, Richland, Washington.

PNL, 1991, Quality Assurance P7an for Activities Conducted by the Analytical Chemistry Laboratory (ACL), MCS-033, Rev. 0, Pacific Northwest Laboratories, Richland, Washington.

Silvers, K. L., 1997, K East Basin Canister Sludge Sample Analysis, Pacific Northwest National Laboratory, Richland, Washington.

Silvers, K. L., 1995, K Basin Sludge Sample Analysis, Basin Floor and Weasel Pit, Pacific Northwest Nationa] Laboratory, Richland, Washington.

Trimble, D. J., and T. L. Welsh, 1997a, Cesium-137 in K West Basin Canister Water, HNF-SD-SNF-ANAL-014, Rev. O, Duke Engineering and Services Hanford, Inc., Richland, Washington.

Trimble, D. J., 1997, "K West Basin Canister Sludge Inventory," Internal Memo to D. S. Takasumi, dated 1997, ???, Richland, Washington.

Welsh, T. L., R. B. Baker, B. J. Makenas, and K. L. Pearce, 1995, Sampling and Analysis Plan for S7udge Located in Fuel Storage Canisters of the 105-K East Basin, WHC-SD-SNF-PLN-016, Rev. 0, Duke Engineering and Services Hanford, Inc., Richland, Washington.

Welsh, T. L., R. B. Baker, B. J. Makenas, and K. L. Pearce, 1995, Sampling and Analysis Plan for Floor Sludge of the 105-K East Main Basin and Weasel Pit, WHC-SD-SNF-PLN-006, Rev. 0, Westinghouse Hanford Company, Richland, Washington.

Williams, N. H., 1996, "Sludge Disposal Plan of Execution," Letter 96566039 to E. D. Sellers (RL), dated 1996, Duke Engineering \& Services Hanford, Inc., Richland, Washington.

Willis, N. P., 1993, Hanford Site Waste Acceptance Criteria, WHC-EP-0063-4, Westinghouse Hanford Company, Richland, Washington. 
HNF-4016, Rev. 0

A P PENDIX A

SAMPLING LOCATIONS FOR THE $K$ EAST BASIN

CONSOLIDATED SLUDGE COLLECTION CAMPAIGN

A. L. Pitner

A-1 
HNF-4016, Rev. 0

This page intentionally left blank. 
HNF-4016, Rev. 0

\author{
APPENDIX A \\ SAMPLING LOCATIONS FOR THE $K$ EAST BASIN \\ CONSOLIDATED SLUDGE COLLECTION CAMPAIGN
}

\title{
A.1 INTRODUCTION
}

A total of six sludge samples are to be taken in the consolidated sludge collection campaign (Petersen 1998). Three of the samples will come from canisters containing damaged fuel and three will be collected from various floor locations in the $K$ East Basin. This document provides recommended locations for collecting the sludge samples. The bases for selecting the candidate locations were the in-bas in video survey performed in 1994 (Pitner 1995) and reported floor sludge depth measurements obtained by using a steel ruler and an underwater camera (Melling 1994). Results of previous canister sludge depth measurements performed using an ultrasonic probe (Pitner 1996) were also used to some degree in selecting the candidate sample locations.

\section{A.2 METHODOLOGY}

The consolidated sludge sampler (Hecht 1999) will be used to acquire all sludge samples in this campaign. All samples will be collected from locations under slots in the grating over the basin. For five of the six samples collected, the sampler will operate in the filtered mode and composite samples will be collected from various locations. For the one "single pull" sample, the sampler will not be operated in the filtered mode and a float valve will be employed to terminate the sample collection. The "single pull" sample will be a sludge/water mixture that fills the 10 liter collection vessel. The remaining samples are targeted for total sludge sample volumes of about 2.5 liters each.

Sample KC-1 will be a single pull sample collected from a canister barrel containing highly damaged fuel. Sample $\mathrm{KC}-2$ will be a consolidated sample of sludge drawn from canisters containing highly damaged fuel in all three bays of the basin. Sample KC-3 is similar to Sample KC-2, except the canisters selected contain moderately damaged fuel. Sample $\mathrm{KC}-4$ will be taken from the floor between slotted barrels of canisters containing highly damaged fuel, and will also be a consolidation of sludge drawn from locations in all three bays. Sample KC-5 will again be a consolidation of floor sludge samples drawn from known deep sludge areas in all three bays. Sample KC -6 will be taken from the floor near the North Loadout Pit in an area where spilled IXM beads are known to be present.

For the canister sludge samplings, before and after measurements of sludge depths will be made using a an ultrasonic system similar to that employed in the previous canister sludge depth campaign (Pitner 1996). Canister barrels for this sampling campaign were selected to ensure that the ultrasonic probe could be inserted between fuel assemblies. Multiple depth 
measurements in each canister barrel will be made and averaged before and after sampling to provide an estimate of the sludge volume removed (the calculation will consider the number of fuel assemblies loaded in the canister barrel).

For the single pull sample, the ultrasonic sludge depth measurements will provide an estimate of the total volume of sludge collected from the barrel containing highly damaged fuel. For the remaining composite canister sludge samples, running totals of sludge volumes will be calculated after each barrel sampling. Multiple barrels in each bay may be sampled to obtain the desired sludge quantities. An objective is to obtain roughly one-third of the goal 2.5 liter consolidated sludge sample from each bay of the basin.

For the floor sludge samples, the estimated volumes obtained will be based on visual observations of sludge depths and suctioned areas. Sludge depths will be measured before and after sampling using a tube with depth markings readable by a video camera [i.e., marked isolation tubes used in prior floor sludge sampling (Baker 1998c)]. The sampled floor area will be visually estimated using the video camera. Sampling will be such that a full range of sludge (from upper surface to floor) is drawn.

It is anticipated that more sludge is available for sampling in canisters containing highiy damaged fuel than in canisters containing moderately damaged fuel. Accordingly, three or more prospective locations are identified in each bay for the highly damaged fuel sampling, while a minimum of six locations are identified in each bay for the moderately damaged fuel sampling to provide a sufficient number of candidates to meet volume goals for the siudge samples.

The consolidated sampling of highly damaged fuel canisters will be conducted prior to the sampling of sludge from moderately damaged fuel canisters. It is not anticipated that a1l three highly damaged fuel canisters will need to be sampled in each bay to obtain the targeted sample quantity from each bay (approximately $800 \mathrm{ml}$ ). At the Test Engineer's judgement the unused candidate barrels containing highty damaged fuel (including the single pull sample) would then be available to supplement sludge collections from the moderately damaged fuel canisters to meet total sludge volume goals if necessary. These highly damaged barrels would only be used if the moderately damaged fuel canisters were significantly short of the needed sample material volume.

\section{A.3 SAMPLE LOCATIONS}

The candidate locations for collecting the six sludge samples are summarized in Table A1. For the single pull sample (KC-1), either one of the two locations given may be used to collect the sludge sample. For the consolidated canister samples (KC-2 and $\mathrm{KC}-3)$, multiple locations are identified in each bay to meet sampling objectives. Sampling may begin in any bay, with any location listed. Alternate locations listed can then be sampled as needed to meet sample volume goals (approximately 800 m $\ell$ from each bay). Once the goal sludge volume is obtained from a given bay, sampling shall proceed to another bay to continue the consolidated sludge sample collection. 
All candidate canisters in this listing are aluminum canisters. Fuel elements placed in stainless steel canisters were generally in relatively good condition, and not Tikely to contribute significant fuel corrosion products to the siudge inventory. An objective of the canister sludge sampling is to collect sludge from canisters with damaged fuel (Petersen 1999). Since $K$ Basin Operations has placed all significantly damaged fuel in aluminum canisters, these canisters provide all the candidates for the canister sludge samplings.

Several locations are also identified in each bay for the KC-4 floor sludge sample. This sludge is to be collected from the floor between the barrels of slotted canisters containing highly damaged fuel. Any one of the locations listed in each bay may be selected for the sampling. Multiple locations from each bay will be sampled to comprise this consolidated sample to obtain the volumes required.

Given the general sampling location criteria of the prior paragraphs, specific descriptions of the sample types and candidate locations follow. Where sludge depths were previously measured, the measured depth is indicated in parentheses following the canister barrel identification. Photographs of candidate locations are included, but these are as they appeared in 1994. With over four years of additional corrosion having elapsed, current appearances may be notably different. Video tape from underwater cameras will be used to provide current status of the fuel canisters and floor areas sampled during this campaign. These will become part of the resulting sample data basis.

\section{A.3.1 Sample KC-1}

This sample will be a single pull sample collected from a canister barrel containing highly damaged fuel. This sludge material will be the most representative of the settled sludge in the basin with respect to particle size and condition since no filter is used and all particles are retained as suctioned from the canister. Sampling will be terminated by a check valve once the 10 liter container is filled with a mixture of sludge and water.

The two locations identified for this sampling [1236 W (3.4 in.--as noted, throughout the balance of text sludge depths in canisters are indicated in parentheses after cubical numbers)] and 4569E (4.6 in.), are shown in Figures A1 and A2, respectively. Each of these canister barrels contains fuel elements that show substantial corrosion and voiding at the top end and should therefore contain significant sludge inventories. The canister in location 4569 has barrels with solid sides, while that in location 1236 has barrels with slotted sides; thus the former candidate (4569) might be expected to have better retained its sludge inventory. Conversely, location 1236 is also identified as a candidate for "between barrels" sampling of floor sludge (see Section A.3.4), which could influence the selection should there be an incentive to obtain sludge samples from both inside and outside a given slotted canister. 
HNF-4016, Rev. 0

\section{A.3.2 Sample KC-2}

This sample will be a consolidated sample of sludge taken from canisters containing highly damaged fuel in each of the three bays. Based on ultrasonic measurements of before and after sludge depths for each canister sampling, multiple samplings in the same bay may be required to achieve the targeted sludge volumes (approximately $800 \mathrm{~m} \ell$ per bay). Sludge extractions from all three bays should collectively total about 2.5 liters in the consolidated sample container.

The candidate canister barre]s selected from the east bay [668E (3.2 in.), 668W, and $2229 \mathrm{E}$ (3.3 in.)], are shown in Figures $A 3, A 4$, and $A 5$. Center bay candidate canister barrels are $2904 \mathrm{~W}, 4564 \mathrm{E}, 4564 \mathrm{~W}$, and $4571 \mathrm{E}$, as shown in Figures $A 6$ through $A 9$. West bay candidates are $6068 \mathrm{~W}, 6070 \mathrm{~W}$, and $6071 W$ (8.7 in.), as shown in Figures $A 10, A 11$, and $A 12$. All of these candidates contain fuel elements that show significant voiding on their top ends and should thus offer substantial sludge inventories from which to sample.

\section{A.3.3 Sample $\mathrm{KC}-3$}

This sample will be collected in a similar fashion as that described for Sample KC-2 above, but will be taken from canisters with lesser levels of fuel degradation. Fuel elements in these canisters show definite indications of failed cladding with significant reacted fuel present, but do not display the extensive fuel voiding (at least in their 1994 appearances) shown in those candidate canisters chosen for the $\mathrm{KC}-2$ sample.

Because of the lesser degree of fuel damage in these canisters, sludge inventories in individual barrels may be less and a greater number of sludge samplings may be required to obtain the targeted $800 \mathrm{~m} \ell$ per bay. Accordingly, at least six candidate locations are identified for each bay. For the east bay, the candidate barrels are 450E, 455W, 1234E, 1252W, 2024E, and 2031W, as shown in Figures A13 through A18. Center bay candidates are 2905E, 2943W, $3125 \mathrm{~W}, 3727 \mathrm{~W}$ (3.0 in.), 3937W, and $4138 \mathrm{~W}$ (3.3 in.), as shown in Figures A19 through A24. For the west bay, the candidates are 4850W, 4869E, 5056E, $5069 \mathrm{E}$ (2.7 in.), 6451E, 6452E, 6757W, and 6760W, as shown in Figures A25 through $\mathrm{A} 32$. The sludge inventories in 1ocations $6757 \mathrm{~W}$ and $6760 \mathrm{~W}$ likely contain IXM resin beads that were spilled in this area and would only be used as a last resort as enhanced concentration of IXM beads is being addressed separately (Sample KC-6).

As indicated earlier, should collected sludge volumes in any one fall less than the targeted $800 \mathrm{~m} \ell$ level after all candidate barrels have been sampled, the option remains to supplement the sludge collection with material drawn from the unused canisters listed for the $\mathrm{KC}-1$ and $\mathrm{KC}-2$ samples in the same bay. The Test Engineer will decide if sufficient sludge from the moderately damaged fuel has been collected to satisfy goals. While it is desirable to compare the sludge from the two fuel conditions it is a secondary goal compared to obtaining sufficient sludge overall for process testing needs (Petersen 1999). 


\section{A.3.4 Sample KC-4}

This is a floor sludge sample that is collected between the barrels of slotted canisters containing highly damaged fuel. Approximately equal samplings will be drawn from each of the three bays for a total sample volume of approximately 2.5 iters.

For the east bay, one candidate site is in the area of locations 1168 and 1267 (4.8 in.), as shown in Figure A33. These canisters are diagonally adjacent, and both contain degraded fuel. An alternate candidate site in the east bay is in the vicinity of locations 1234 and 1236 (4.6 in.), as shown in Figure A34. These canisters both contain highly damaged fuel and are separated by an empty canister.

For the center bay, a candidate area is around the east barrels of the canisters located in 2952 and 2953, as shown in Figure A35 and identified by the arrows. Another candidate site is in the area of locations 2958 and 2960 , as shown in Figure A36. Both of these slotted canisters contain badly damaged fuel and are separated by an empty canister. An alternate candidate location is 4573, where the west barrel is shown in Figure A37. The east barrel of this canister has an identification disk lying atop the fuel, but badly degraded fuel is evident around the outside of the disk.

One west bay candidate location is 5465 ( $6.8 \mathrm{in.}$ ), as shown in Figure A38. Another site is the combination of 5445 ( 7.5 in.), 5446, and 5447, as shown in Figure A39. In a17 of these candidate locations in the west bay, the canisters have been relocated to other positions in the basin since 1994. However, the movement of these canisters with slotted sides and screened bottoms likely caused substantial sludge quantities to escape from the canisters during their initial upward extraction for relocation. Accordingly, these areas should be replete with corroded fuel deposits.

\section{A.3.5 Sample KC-5}

This sample is being collected to provide material for process testing. It is floor sludge material exclusive of that containing high fractions of corroded fuel products (between barrels) and IXM beads. The total consolidated sample collected should be at least 2.5 liters, and should be taken from all three bays in the basin. Based on the results of previously performed floor sludge depth measurements (Melling 1994), areas were selected where the sludge depth is expected to be on the order of 3 in. to 4 in. or more. These are areas around cubicle locations 2235 (east bay), 4535 (center bay), and 4650 (west bay).

\section{A.3.6 Sample KC-6}

This is another large volume floor sludge sample to be collected for process testing, but taken from an area where IXM resin beads are known to have been spilled. This spill occurred along the west wall of the west bay in the vicinity of the North Loadout Pit. Based on the video survey taken 
in 1994, IXM resin beads can be seen in the area of cubicles ranging from 6753 to 6761. Figure A40 shows beads present on the floor in cubicles 6752, 6753, and 6754 . Areas in cubicles 6755 and 6756 are reserved for a separate floor sludge sampling campaign. However, it is expected that substantial quantities of IXM resin beads remain in the rest of the designated target areas such that a large volume floor sludge sample can be collected with the consolidated sampler that contains significant levels of imbedded IXM beads.

\section{A.4 REFERENCES}

Hecht, S. L., 1999, System Design Description for the Consolidated Sludge Sampling System for $K$ Basins Floor and Fuel Canisters, HNF-3971, Rev. 0, Duke Engineering \& Services Hanford, Inc., Richland, Washington.

Melling, T. A., 1994, Sludge Measurement Results for 105-K East Basin, WHC-SD-WM-ANAL-037, Rev. 0, Westinghouse Hanford, Richland, Washington.

Petersen, C. A., et al., 1999, Revised Sampling Campaigns to Provide Sludge for Treatment Process Testing, HNF-4015, Rev. 0, Duke Engineering \& Services Hanford, Inc., Richland, Washington.

Pitner, A. L., 1995, K East Basin Underwater Visual Fuel Survey, WHC-SD-SNF-TI-012, Rev. 0, Westinghouse Hanford, Richland, Washington.

Pitner, A. L., 1996, K East Canister Sludge Survey, WHC-SD-SNF-TI-034, Rev. 0, Westinghouse Hanford, Richland, Washington. 
Table Al. Sample Locations.

\begin{tabular}{|c|c|c|c|c|}
\hline \multirow{2}{*}{$\begin{array}{l}\text { Sample } \\
\text { No. }\end{array}$} & \multirow[b]{2}{*}{ Type } & \multicolumn{3}{|c|}{ Location Options ${ }^{1}$} \\
\hline & & East Bay & Center Bay & West Bay \\
\hline $\mathrm{KC}-1$ & $\begin{array}{l}\text { Canister--Single Pull } \\
\text { Highly Damaged }\end{array}$ & $1236 \mathrm{~W}$ & $4569 \mathrm{E}$ & \\
\hline $\mathrm{KC}-2$ & $\begin{array}{l}\text { Canister--Consolidated } \\
\text { High Damage }\end{array}$ & $\begin{array}{l}668 \mathrm{E}, 668 \mathrm{~W} \\
2229 \mathrm{E}\end{array}$ & $\begin{array}{l}2904 \mathrm{~W}, 4564 \mathrm{E} \\
4564 \mathrm{~W}, 4571 \mathrm{E}\end{array}$ & $\begin{array}{l}6068 \mathrm{~W}, 6070 \mathrm{~W}, \\
6071 \mathrm{~W}\end{array}$ \\
\hline$K C-3$ & $\begin{array}{l}\text { Canister--Consolidated } \\
\text { Moderate Damage }\end{array}$ & $\begin{array}{l}450 \mathrm{E}, 455 \mathrm{~W}, \\
1234 \mathrm{E}, 1252 \mathrm{~W}, \\
2024 \mathrm{E}, 2031 \mathrm{~W}\end{array}$ & $\begin{array}{l}2905 \mathrm{E}, 2943 \mathrm{~W}, \\
3125 \mathrm{~W}, 3727 \mathrm{~W}, \\
3937 \mathrm{~W}, 4138 \mathrm{~W}\end{array}$ & $\begin{array}{l}4850 \mathrm{~W}, 4869 \mathrm{E}, \\
5056 \mathrm{E}, 5069 \mathrm{E}, \\
6451 \mathrm{E}, 6452 \mathrm{E}, \\
6757 \mathrm{~W}, 6760 \mathrm{~W}\end{array}$ \\
\hline $\mathrm{KC}-4$ & $\begin{array}{l}\text { Floor--Consolidated } \\
\text { Between Barrels }\end{array}$ & $\begin{array}{l}1168 / 1267 \\
1234 / 1236\end{array}$ & $\begin{array}{l}2952 / 2953, \\
2958 / 2960, \\
4573\end{array}$ & $\begin{array}{l}5465, \\
5445 / 5446 / 5447 \\
\text { (al1 moved) }\end{array}$ \\
\hline $\mathrm{KC}-5$ & $\begin{array}{l}\text { Floor--Consolidated } \\
\text { Process Testing }\end{array}$ & 2235 & 4535 & 4650 \\
\hline KC-6 & $\begin{array}{l}\text { Floor--Consolidated } \\
\text { IXM Beads }\end{array}$ & & & 6753 to 6761 \\
\hline
\end{tabular}

"Locations in $K$ East Basin are indicated by the unique four digit "cubical" numbers, and if applicable also indicate either east ("E") or west ("W") following the four digits referring to the "east" or "west" barrel of the twin barrel canister in this cubical (see Baker 1995; Baker 1998c for summary of K East Bas in cubical numbering conventions).

${ }^{2}$ Canisters with damaged fuel and slotted barrels were located in these positions in 1994. Later these were moved to other locations leaving sludge on the floor that would have dropped out the slots and screened holes in the bottom of the barrels. 
HNF-4016, Rev. 0

This page intentionally left blank.

$A-10$ 
Figure Al. Single Pull Canister Candidate--Location $1236 \mathrm{~W}$.

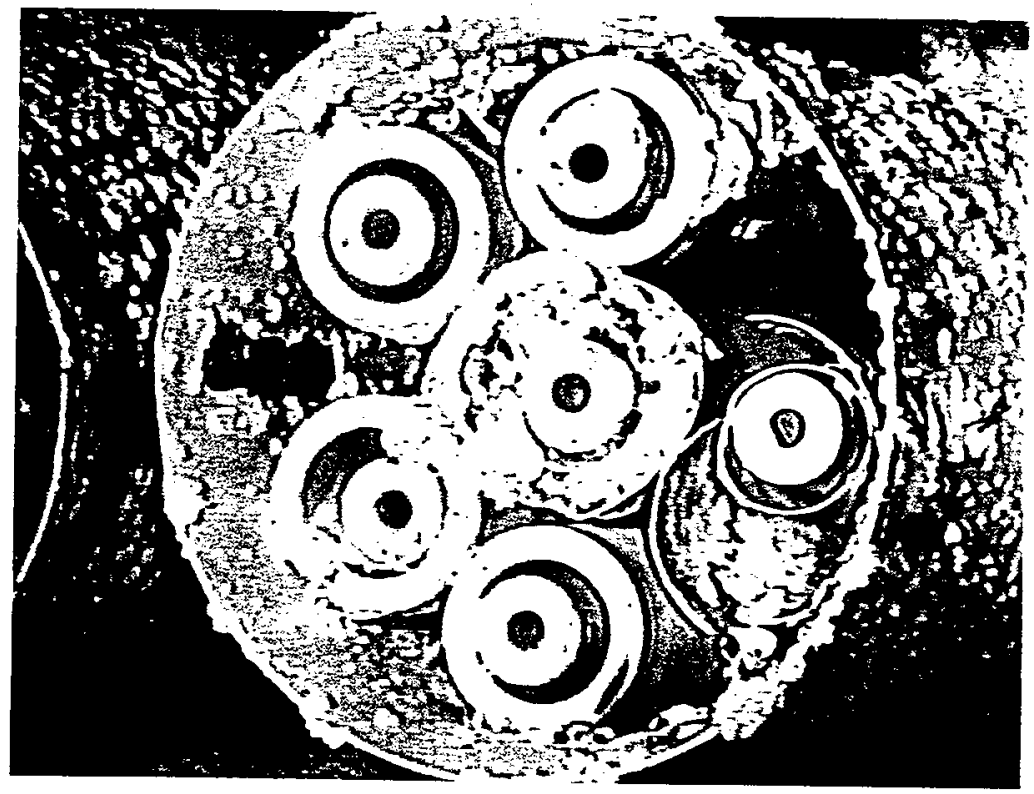


Figure A2. Single Pull Canister Candidate--Location $4569 \mathrm{E}$.

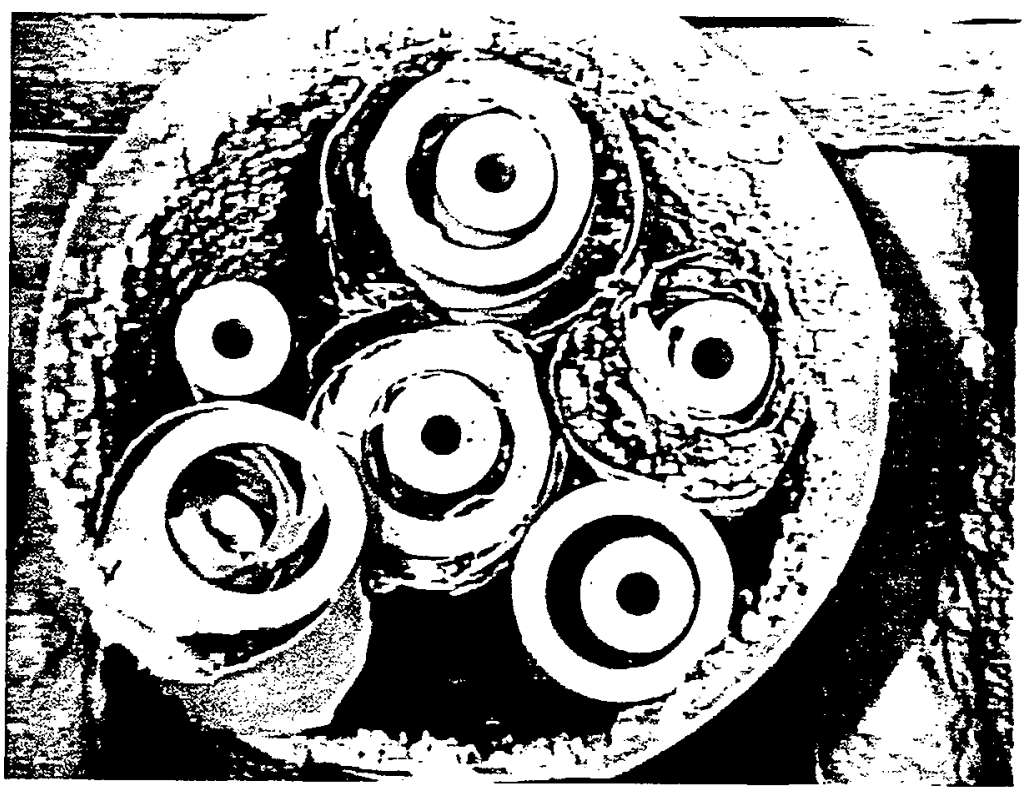


HNF-4016, Rev. 0

Figure A3. High Fuel Damage Canister Candidate/East Bay--Location 668E.

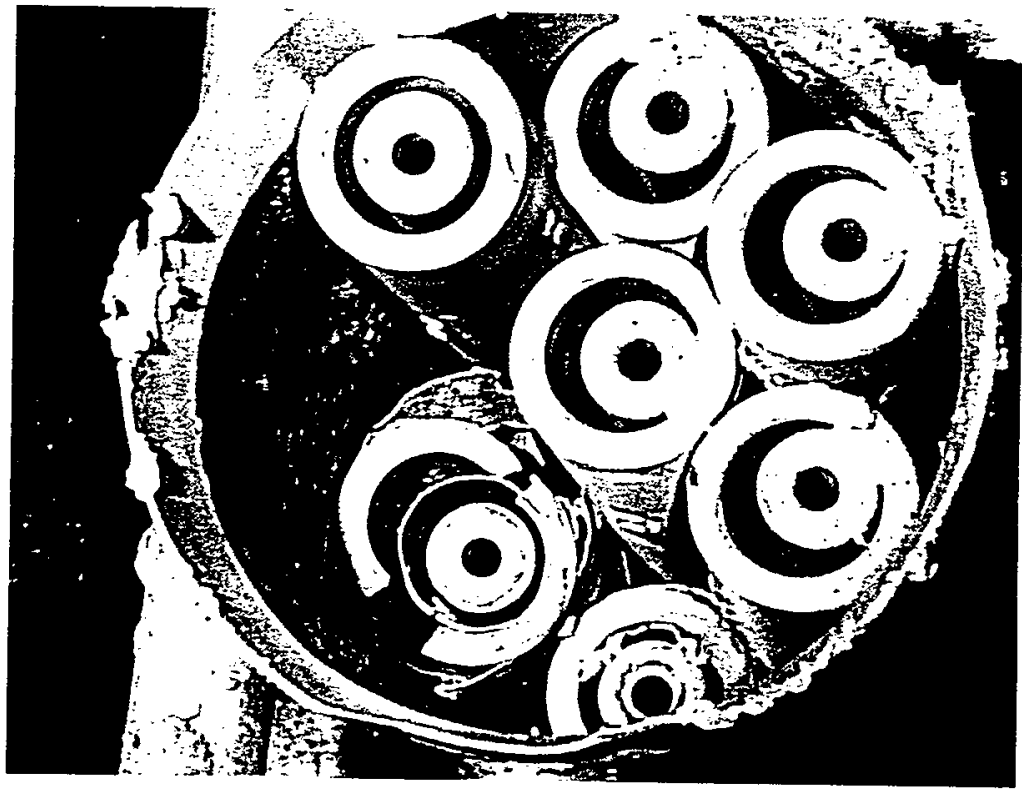


HNF-4016, Rev. 0

Figure A4. High Fuel Damage Canister Candidate/East Bay--Location 668W.

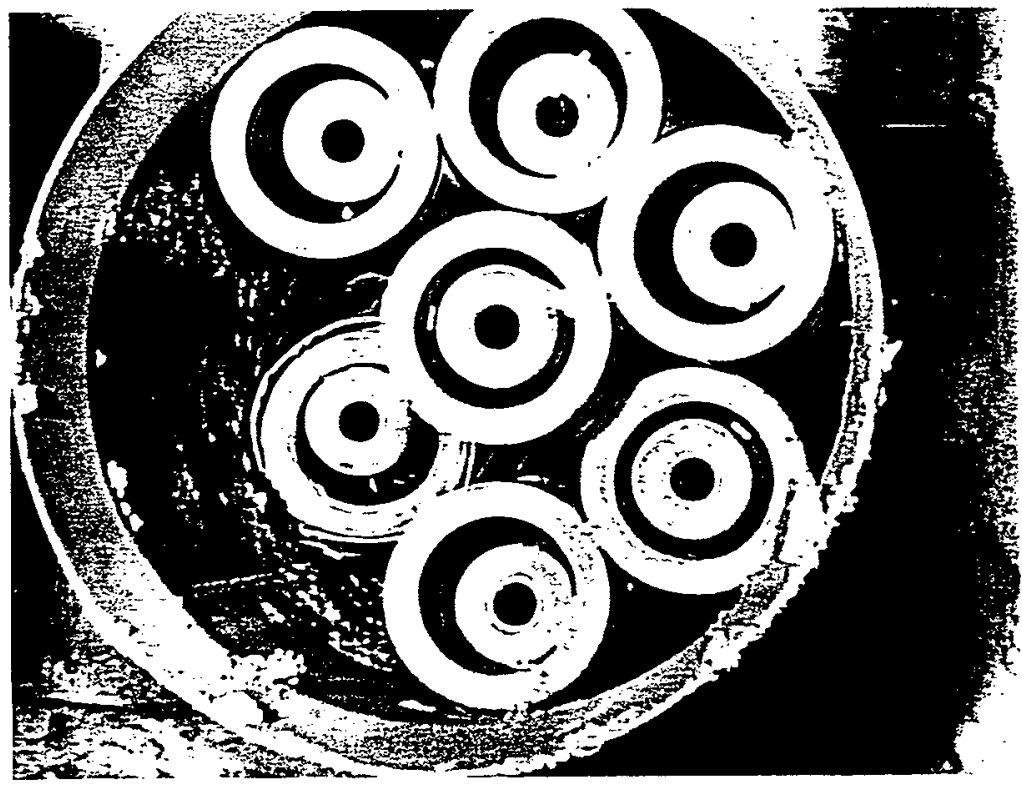


HNF-4016, Rev. 0

Figure A5. High Fuel Damage Canister Candidate/East Bay--Location 2229E.

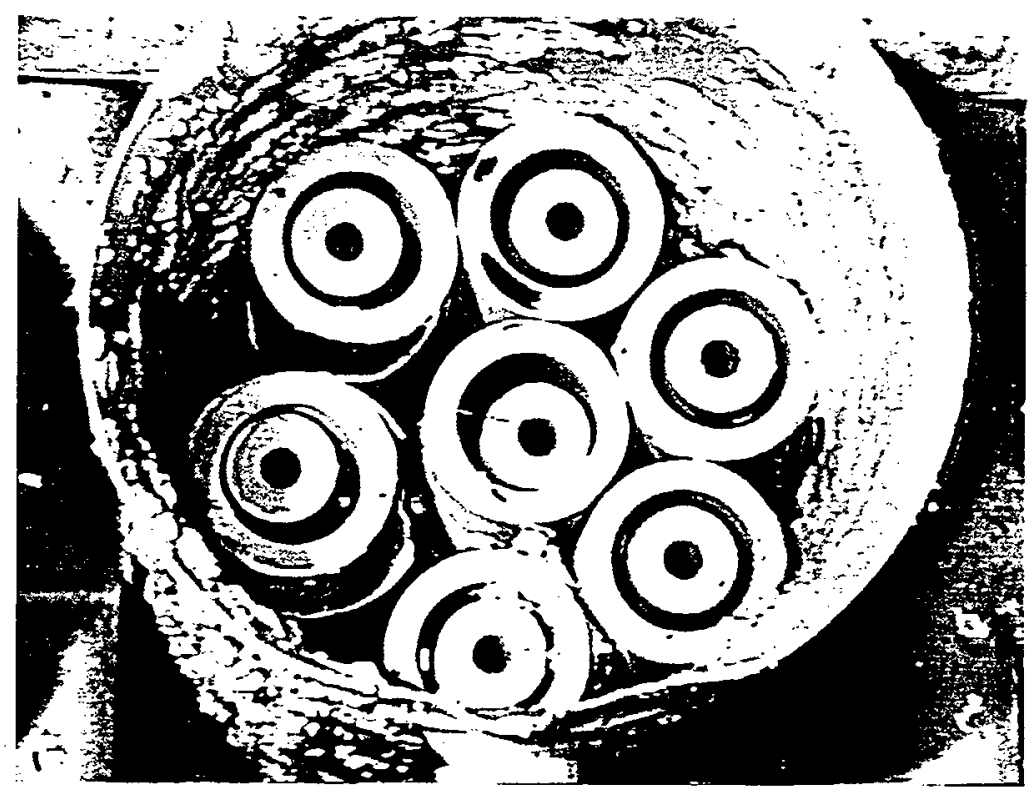


Figure A6. High Fuel Damage Canister Candidate/Center Bay--Location 2904W.

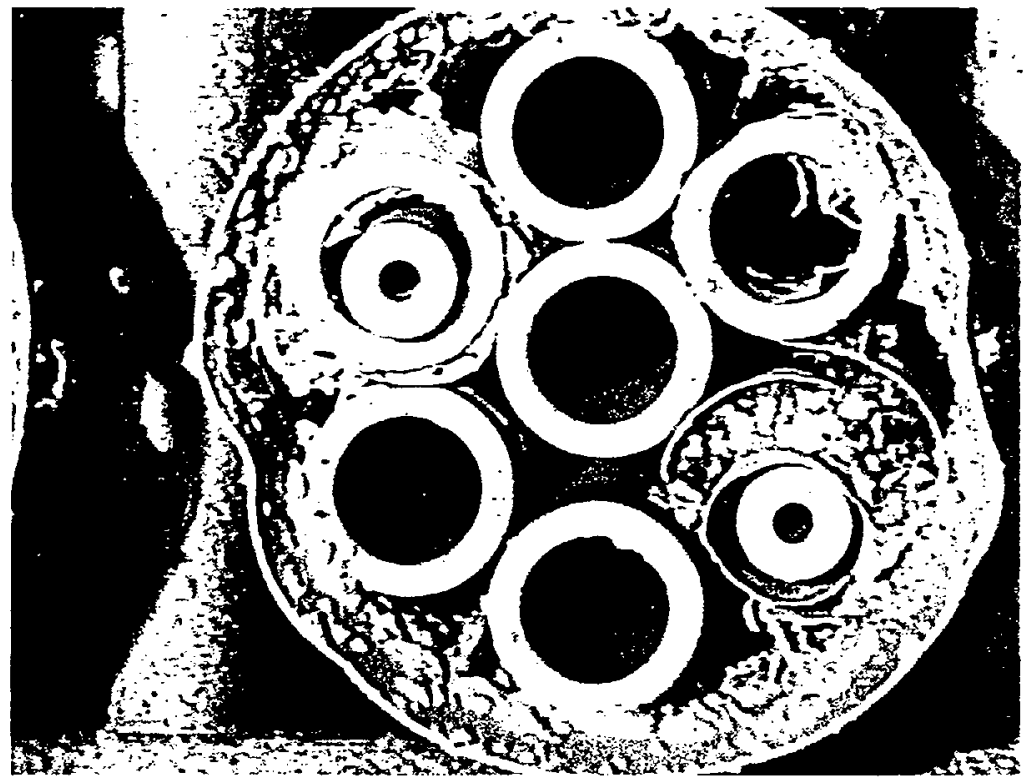


Figure A7. High Fuel Damage Canister Candidate/Center Bay--Location 4564E.

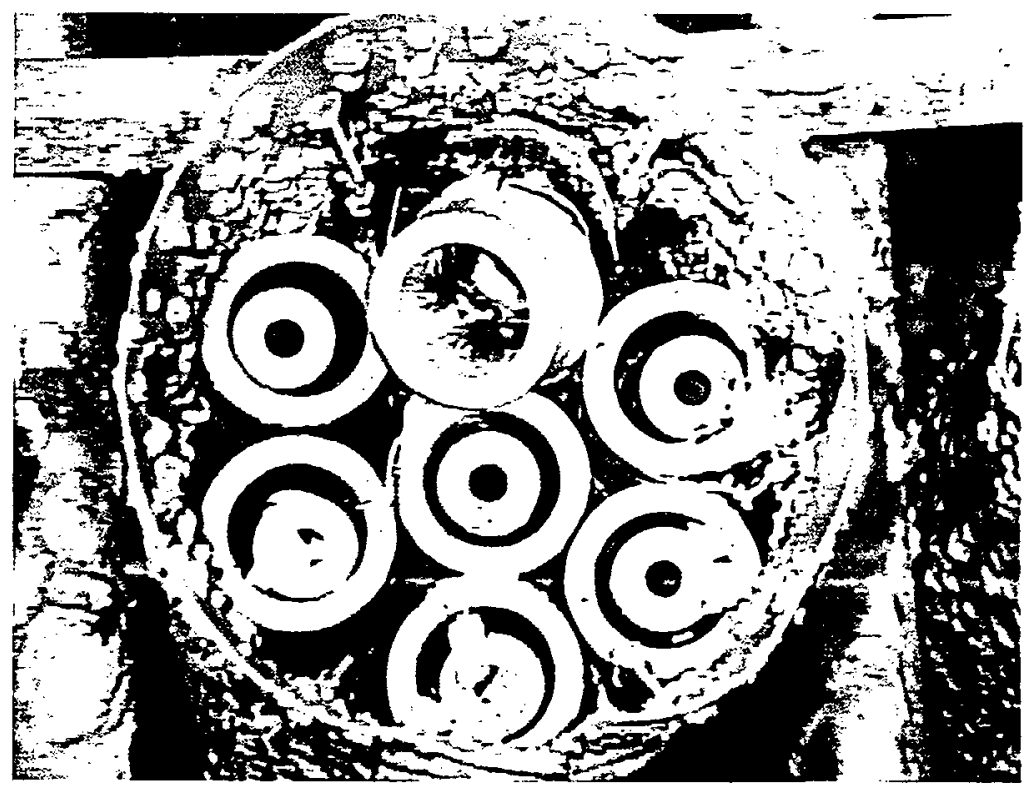


HNF-4016, Rev. 0

Figure A8. High Fuel Damage Canister Candidate/Center Bay--Location 4564W.

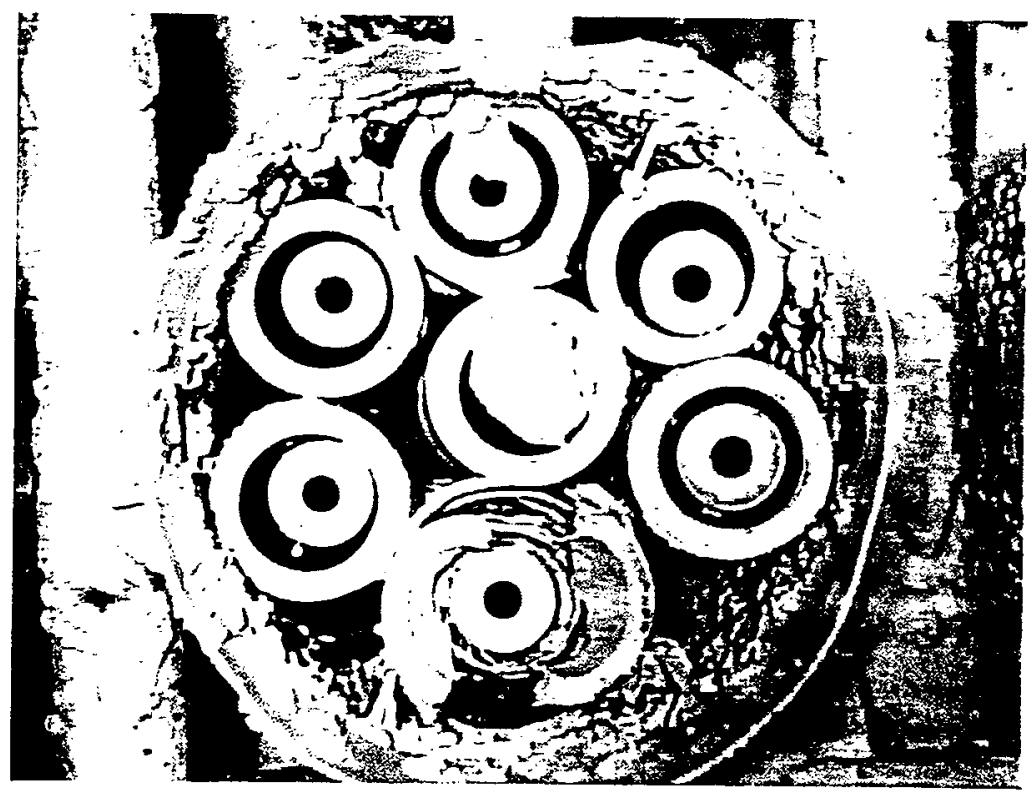


Figure A9. High Fuel Damage Canister Candidate/Center Bay--Location $4571 \mathrm{E}$.

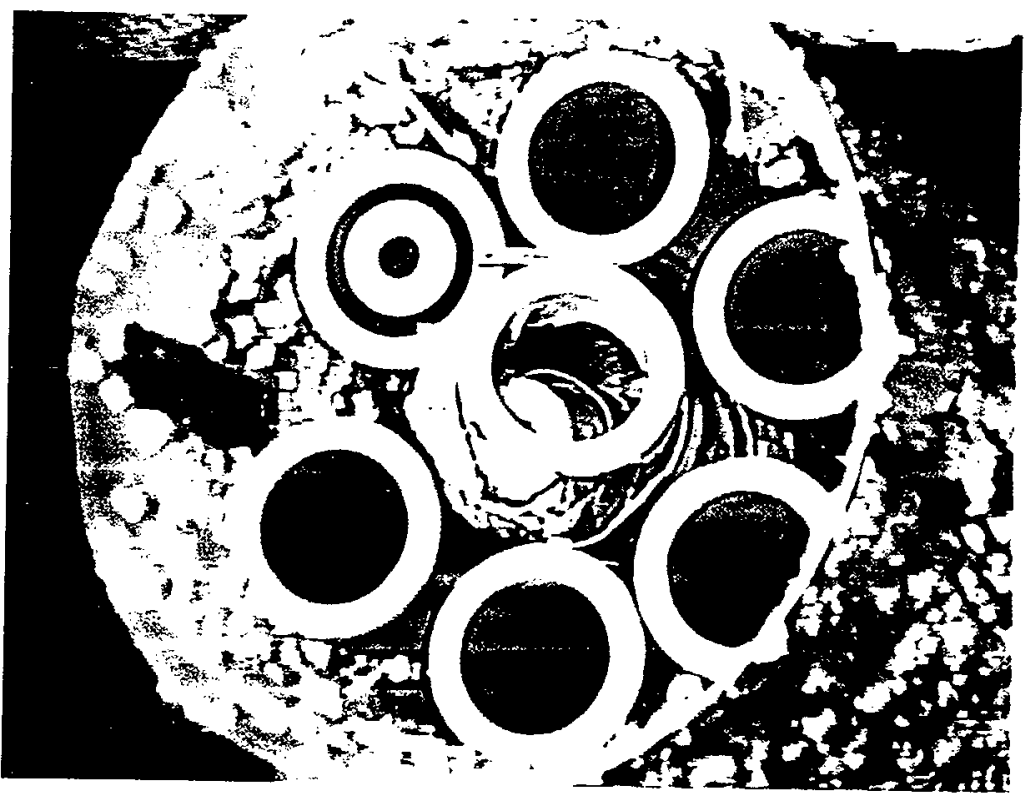


HNF-4016, Rev. 0

Figure A10. High Fuel Damage Canister Candidate/West Bay--Location 6068W.

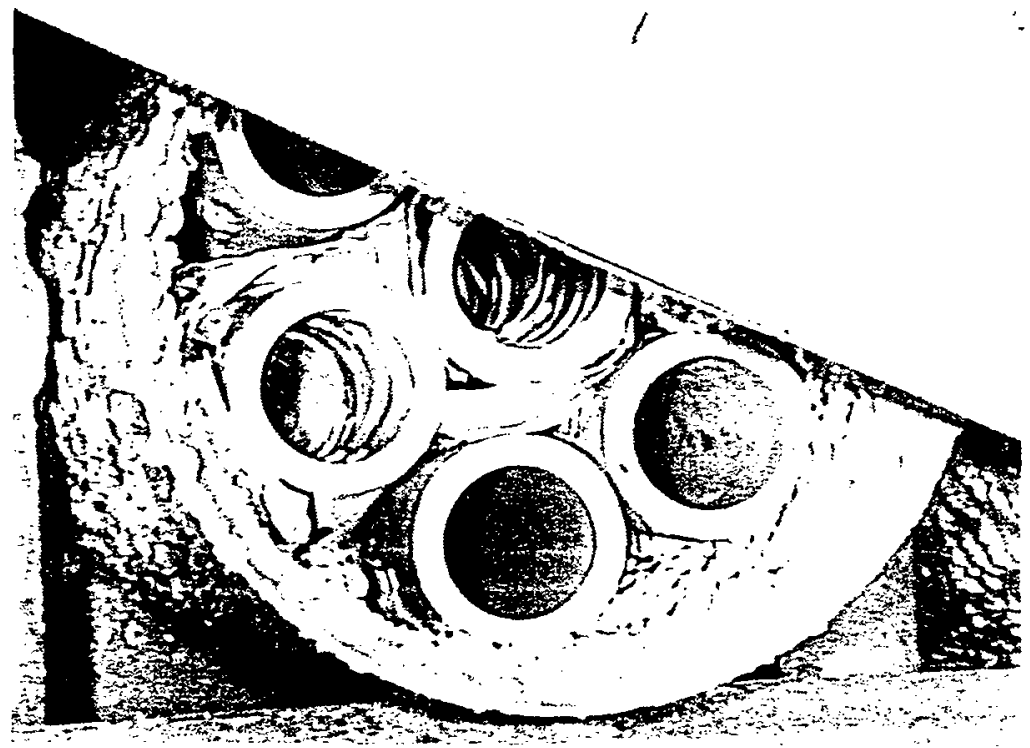


HNF-4016, Rev. 0

Figure All. High Fuel Damage Canister Candidate/West Bay--Location 6070W.

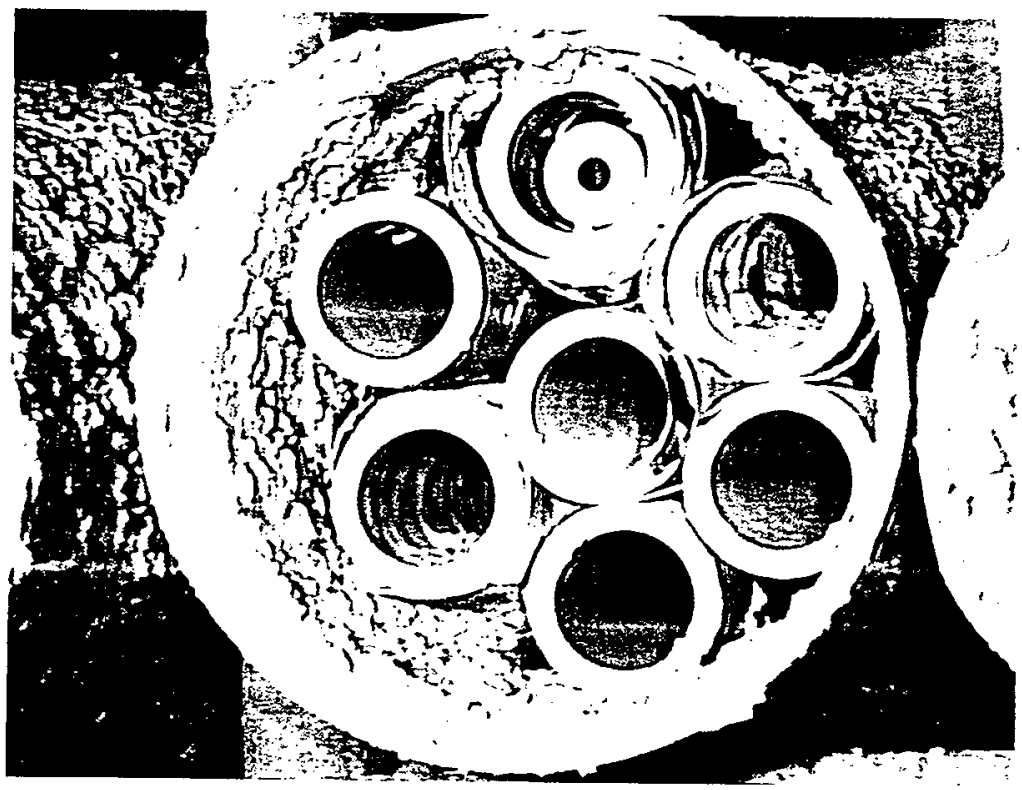


HNF-4016, Rev. 0

Figure A12. High Fuel Damage Canister Candidate/West Bay--Location 6071W.

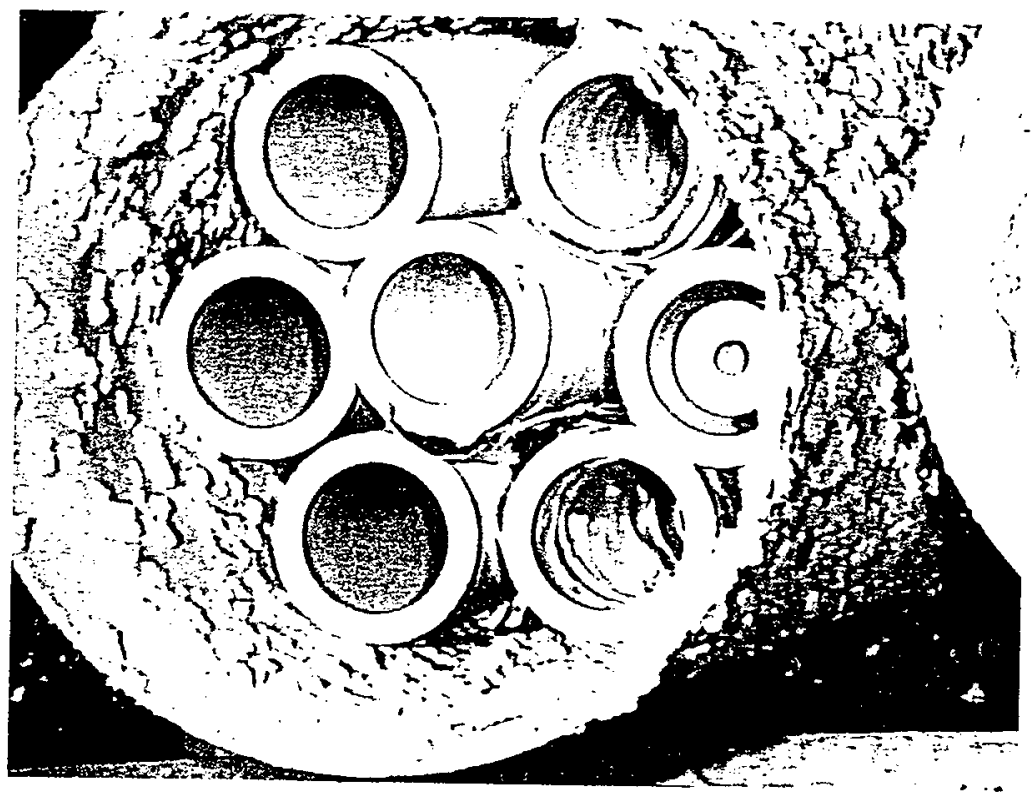


HNF-4016, Rev. 0

Figure Al3. Moderate Fuel Damage Canister Candidate/East Bay--Location $450 E$.

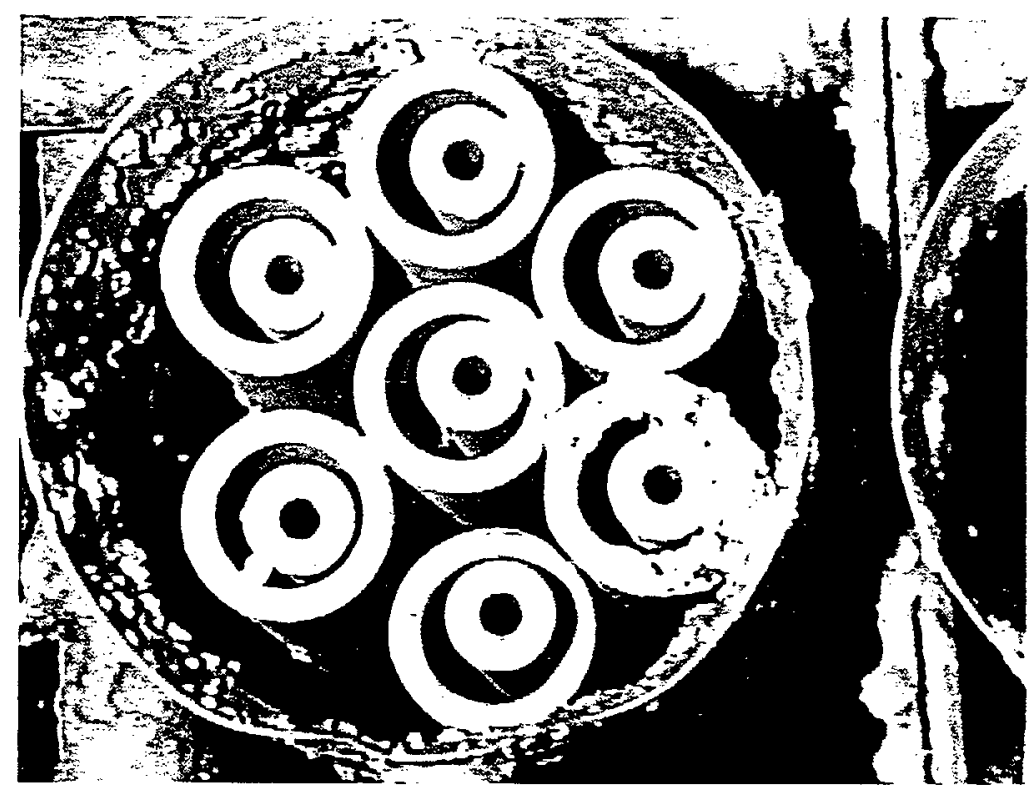


HNF-4016, Rev. 0

Figure A14. Moderate Fuel Damage Canister Candidate/East Bay--Location 455W.

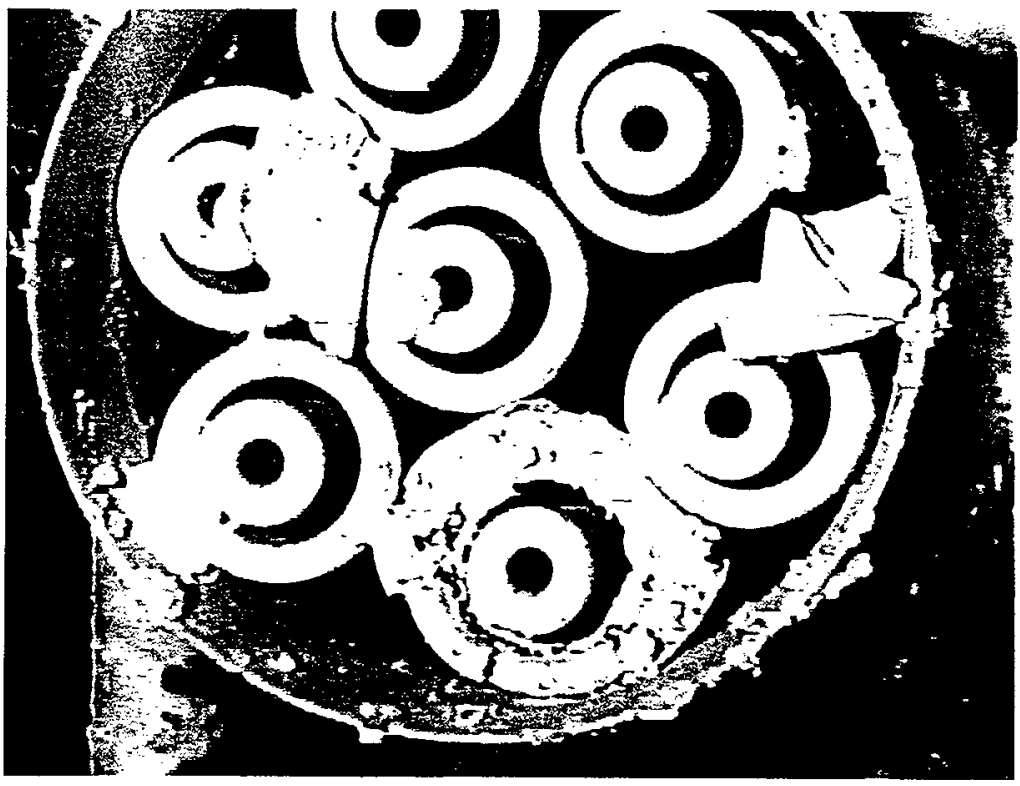


Figure A15. Moderate Fuel Damage Canister Candidate/East Bay--Location 1234 E.

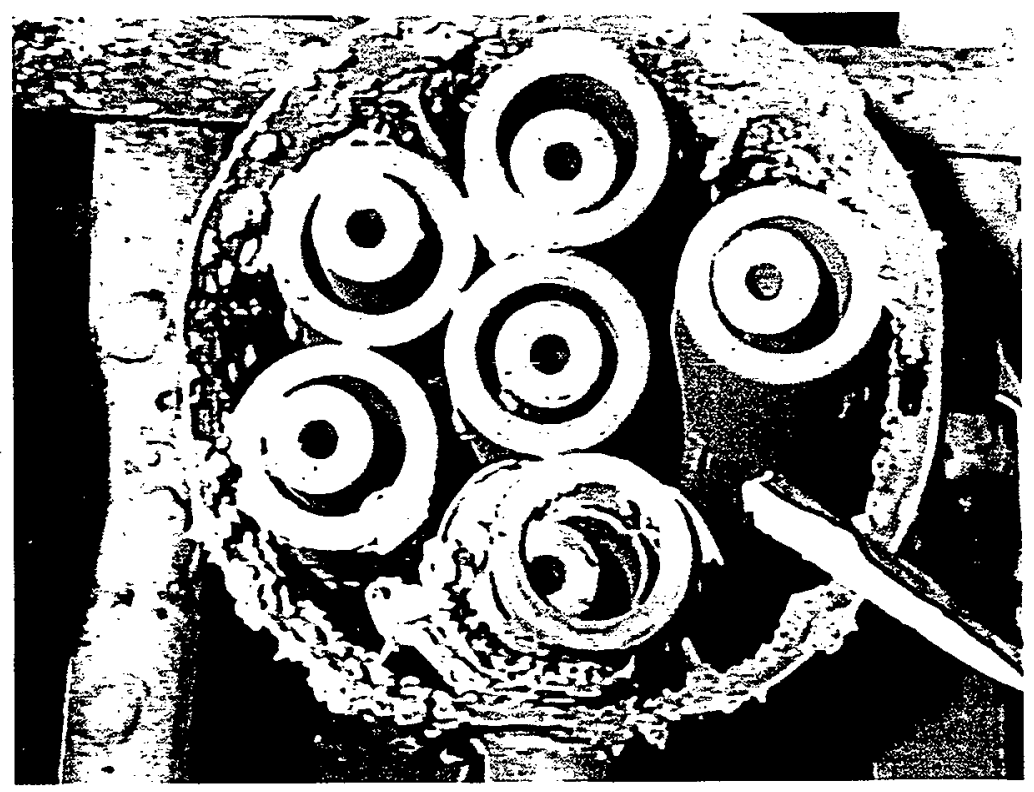


HNF-4016, Rev. 0

Figure AI6. Moderate Fuel Damage Canister Candidate/East Bay--Location 1252W.

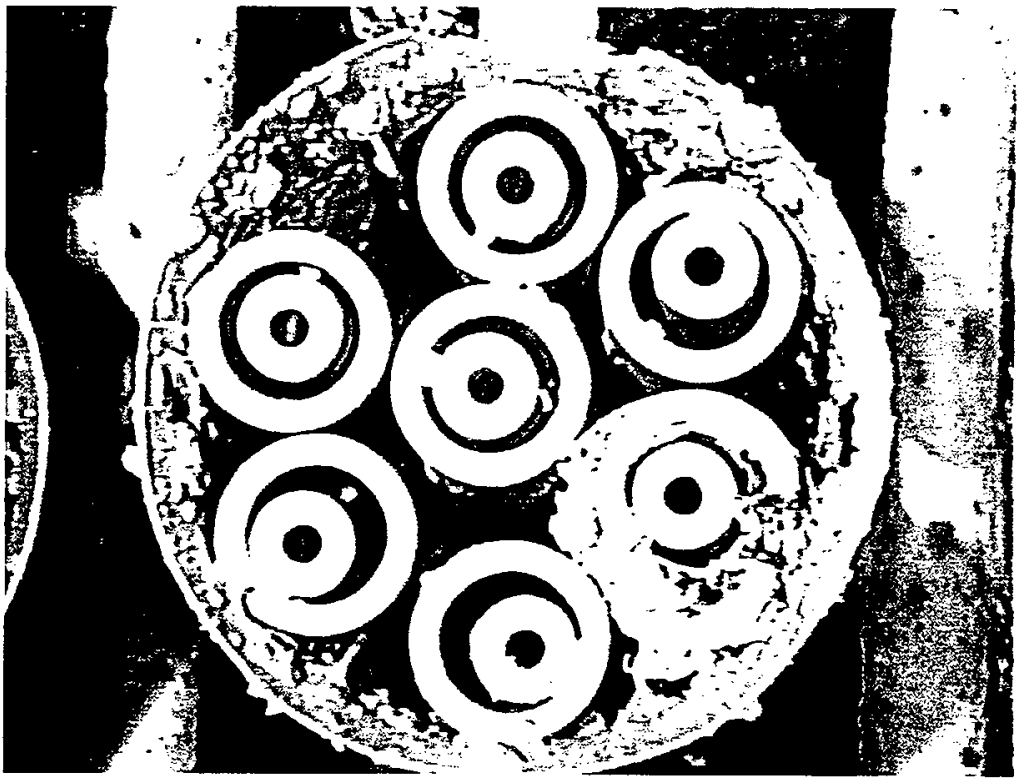


HNF-4016, Rev. 0

Figure A17. Moderate Fuel Damage Canister Candidate/East Bay--Location 2024E.

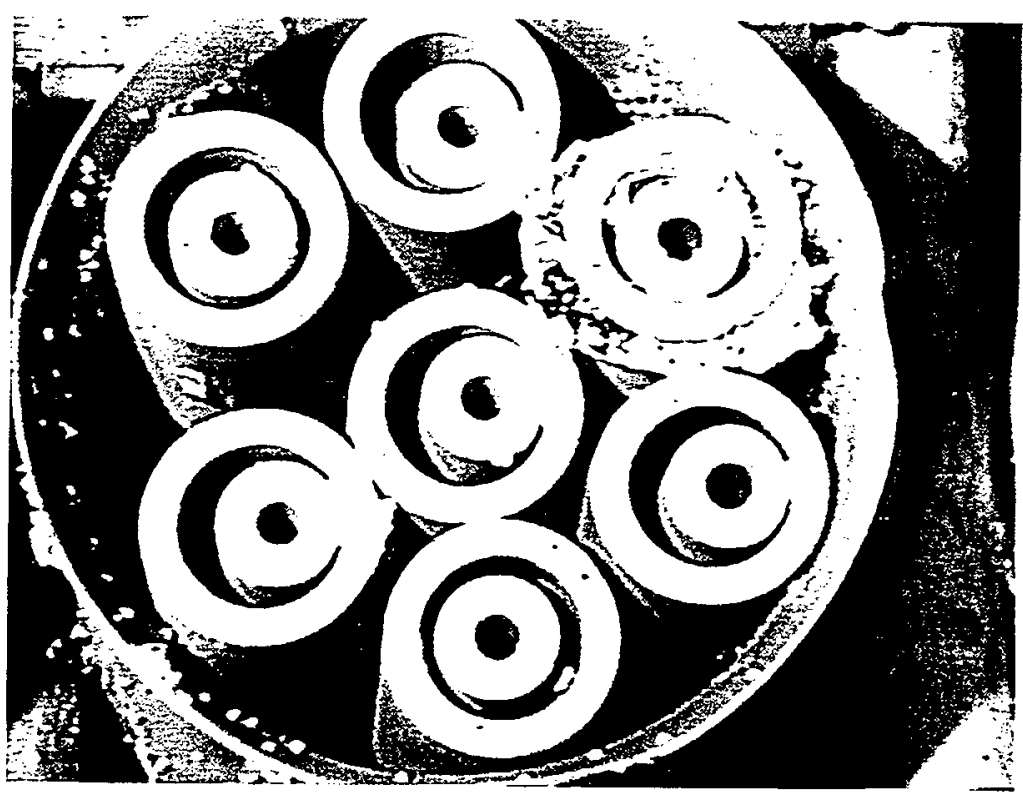


HNF-4016, Rev. 0

Figure Al8. Moderate Fuel Damage Canister

Candidate/East Bay--Location 2031W.

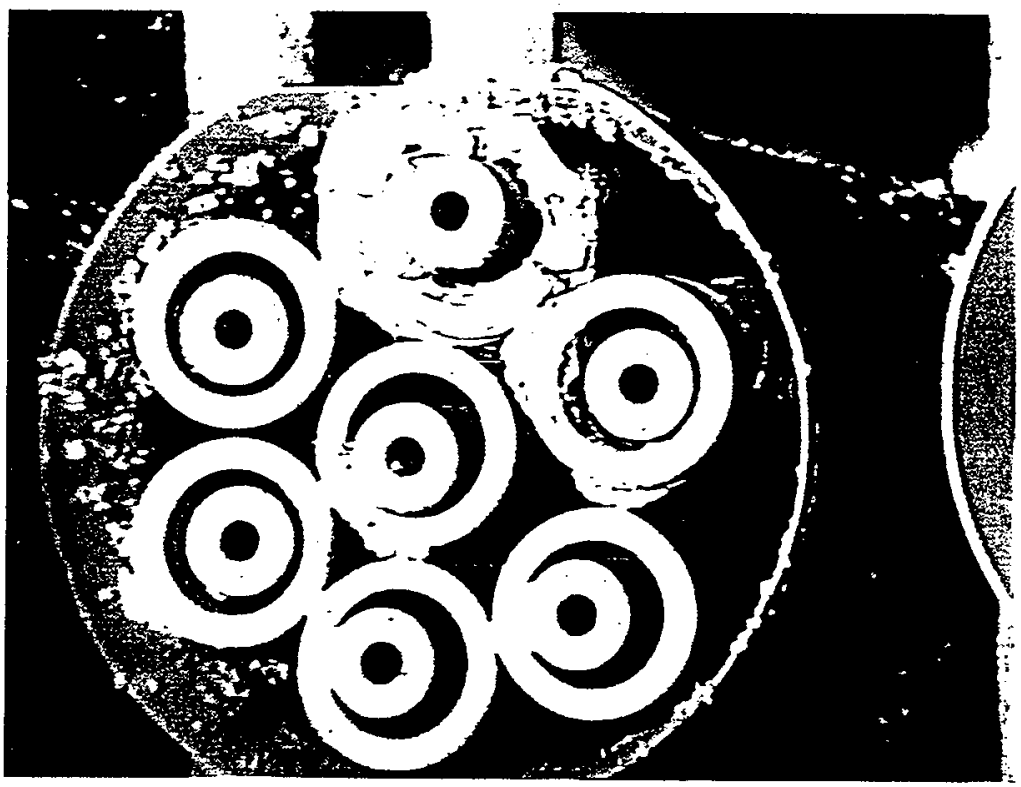


HNF-4016, Rev, 0

Figure A19. Moderate Fuel Damage Canister

Candidate/Center Bay--Location 2905E.

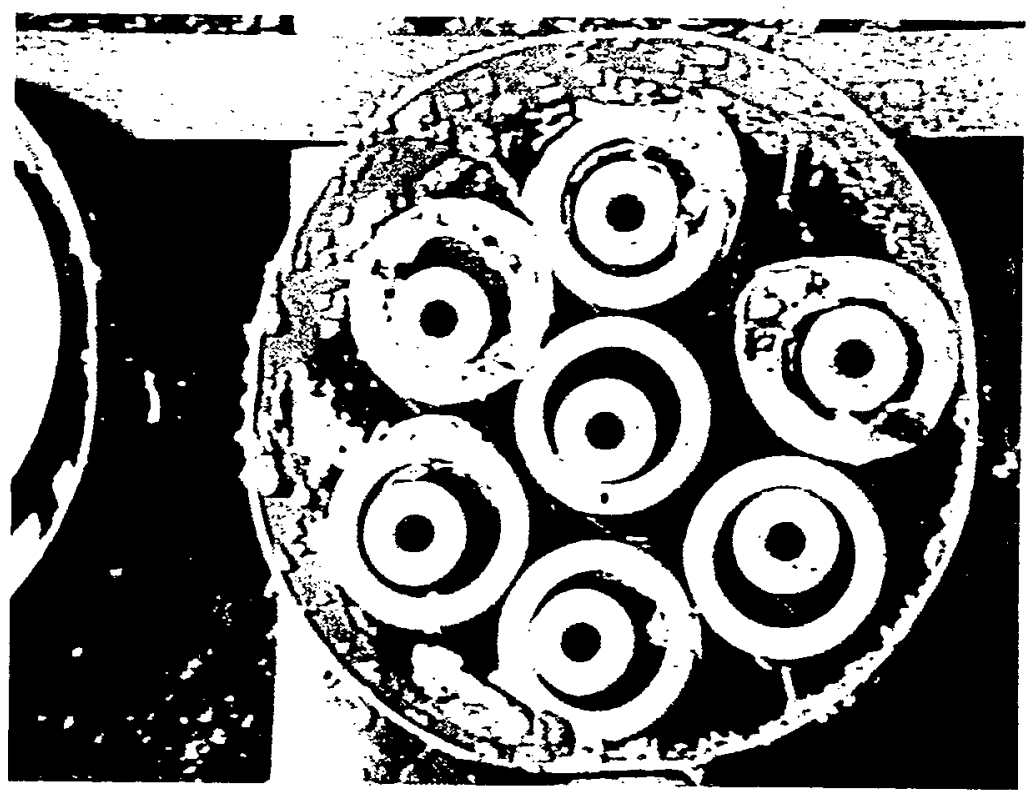


HNF-4016, Rev. 0

Figure A20. Moderate Fuel Damage Canister Candidate/Center Bay--Location 2943W.

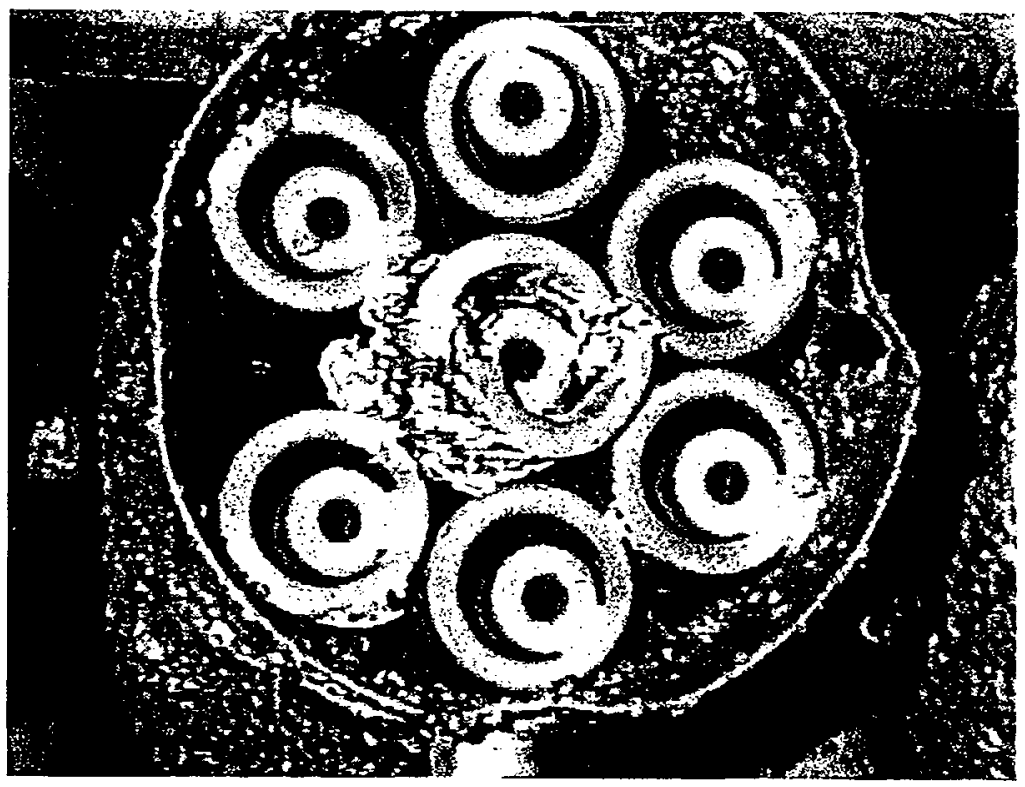


HNF-4016, Rev. 0

Figure A21. Moderate Fuel Damage Canister

Candidate/Center Bay--Location 3125W.

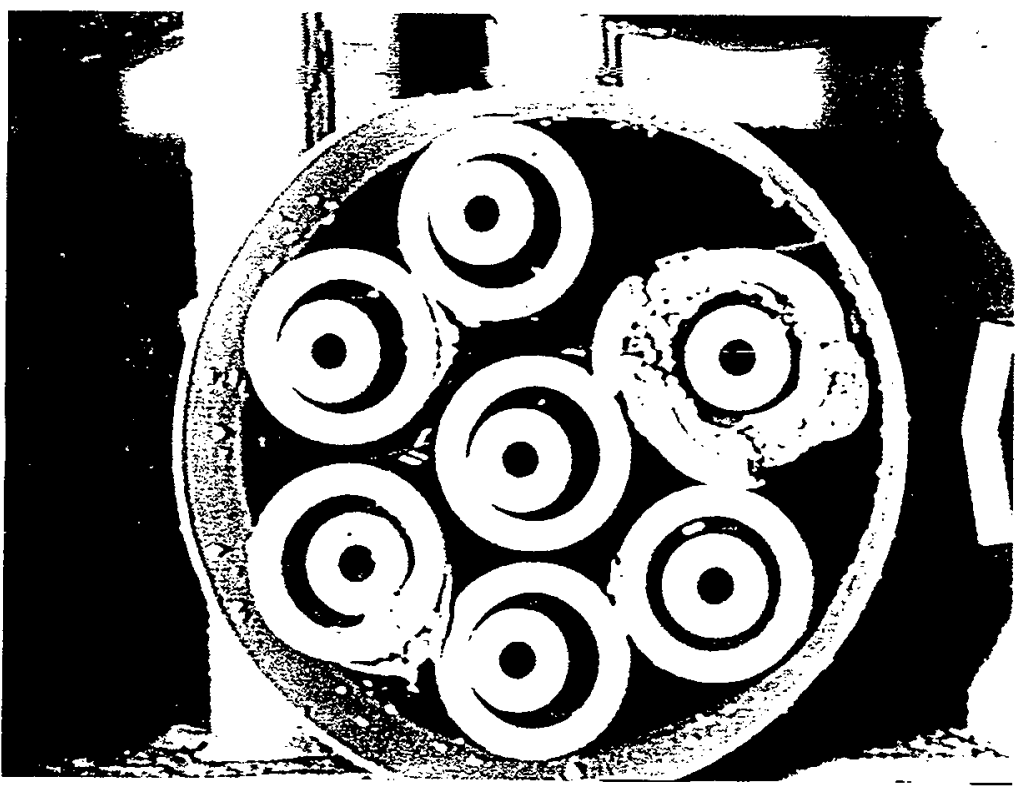


Figure A22. Moderate Fue1 Damage Canister

Candidate/Center Bay--Location 3727W.

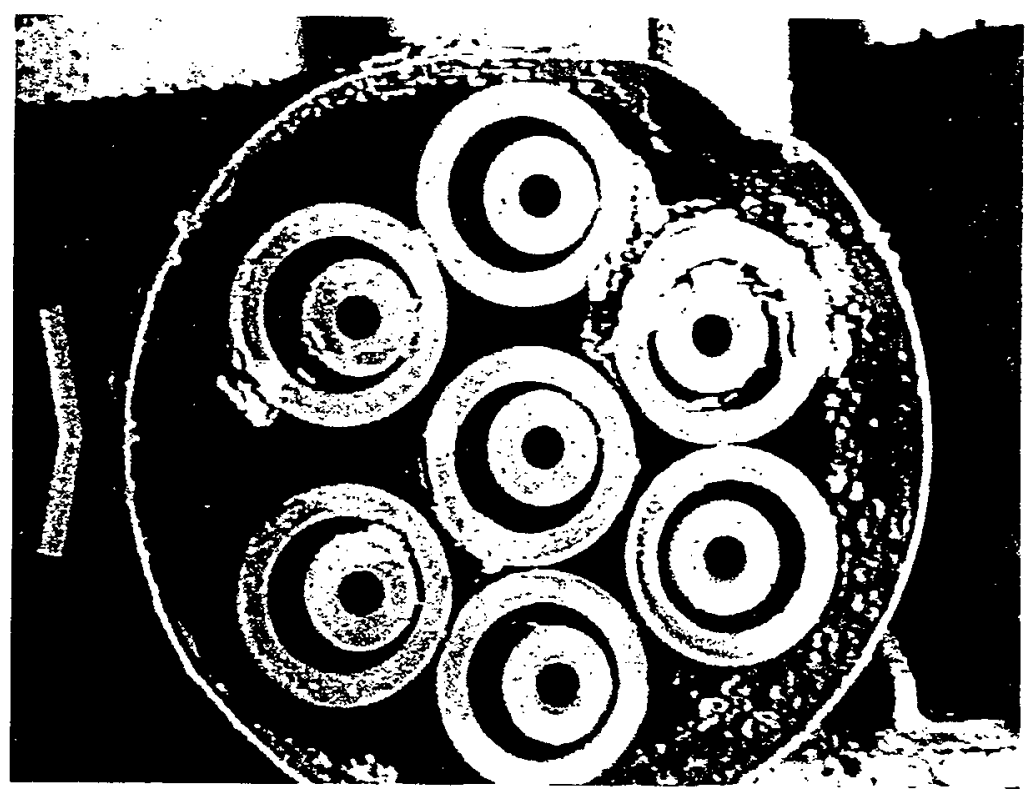


Figure A23. Moderate Fuel Damage Canister Candidate/Center Bay--Location 3937W.

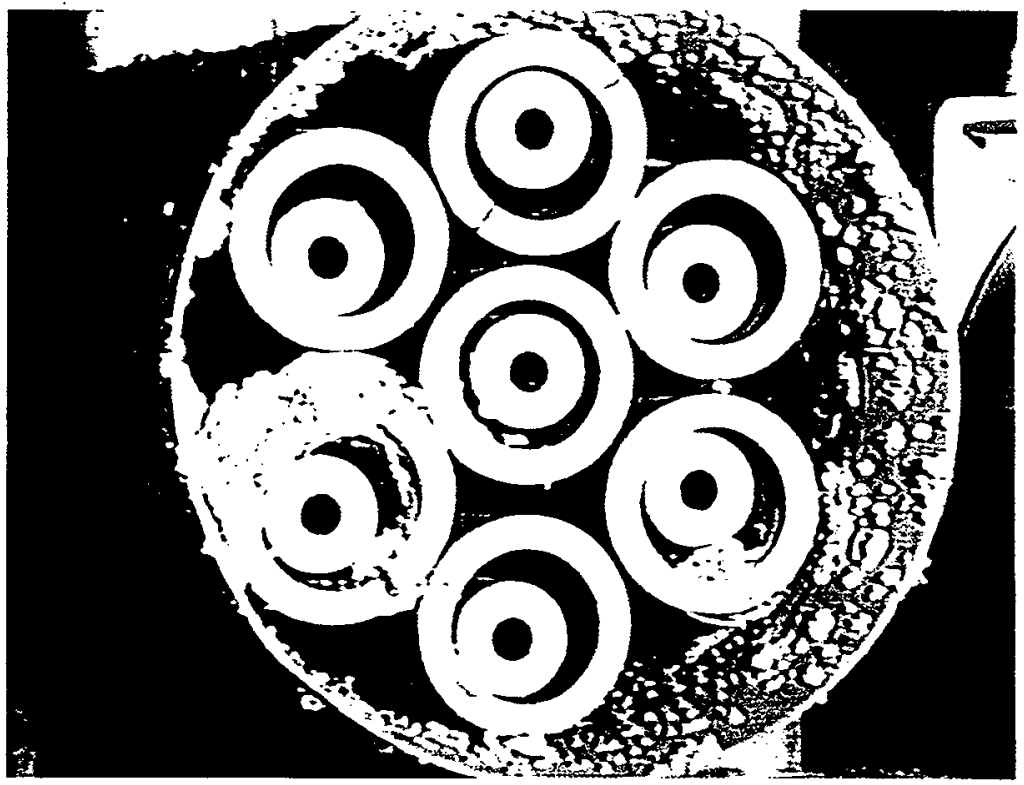


Figure A24. Moderate Fuel Damage Canister

Candidate/Center Bay--Location 4138W.

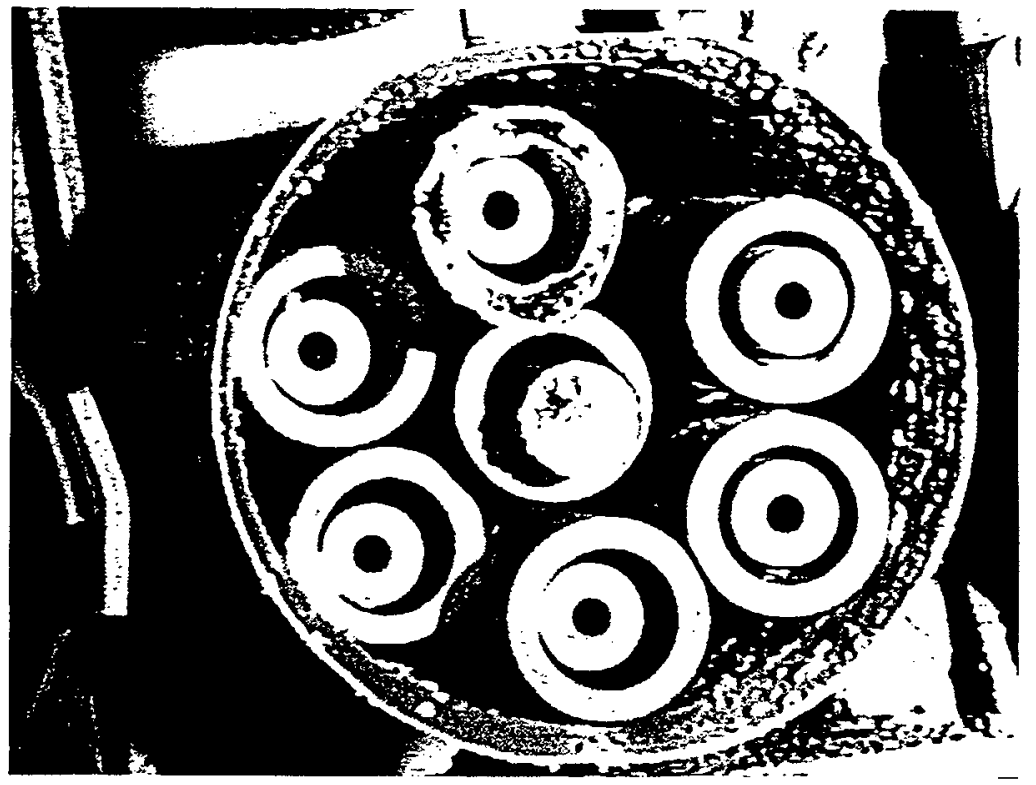


Figure A25. Moderate Fuel Damage Canister Candidate/West Bay--Location 4850 W.

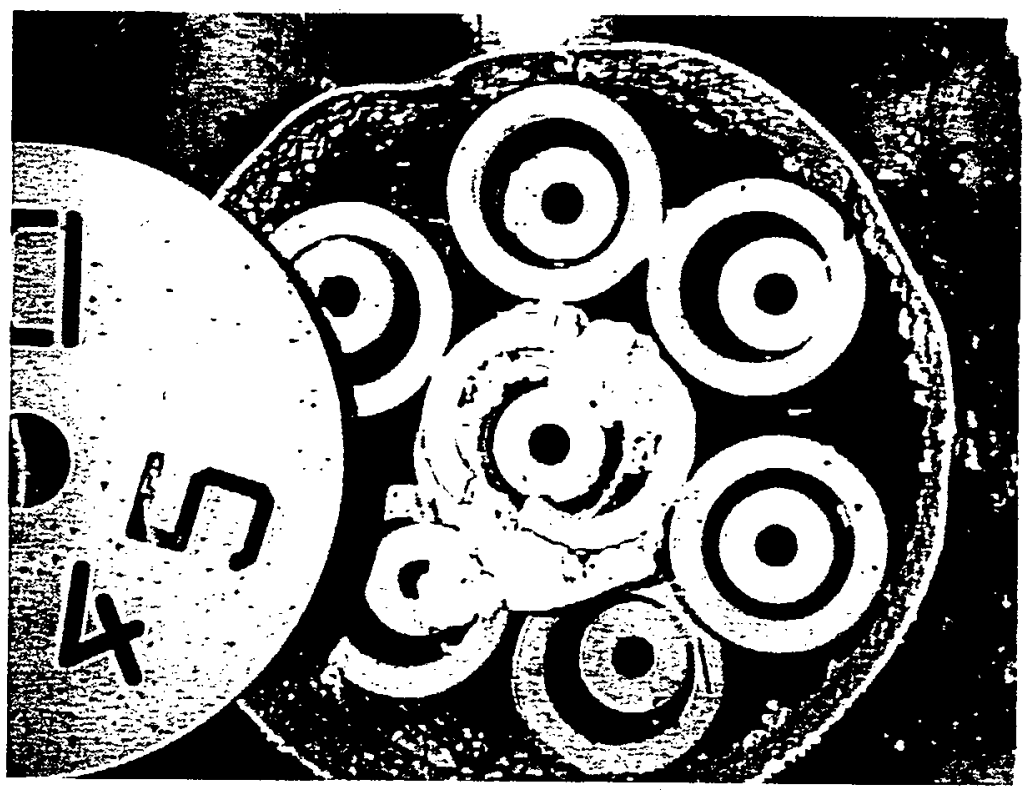


Figure A26. Moderate Fuel Damage Canister Candidate/West Bay--Location 4869E.

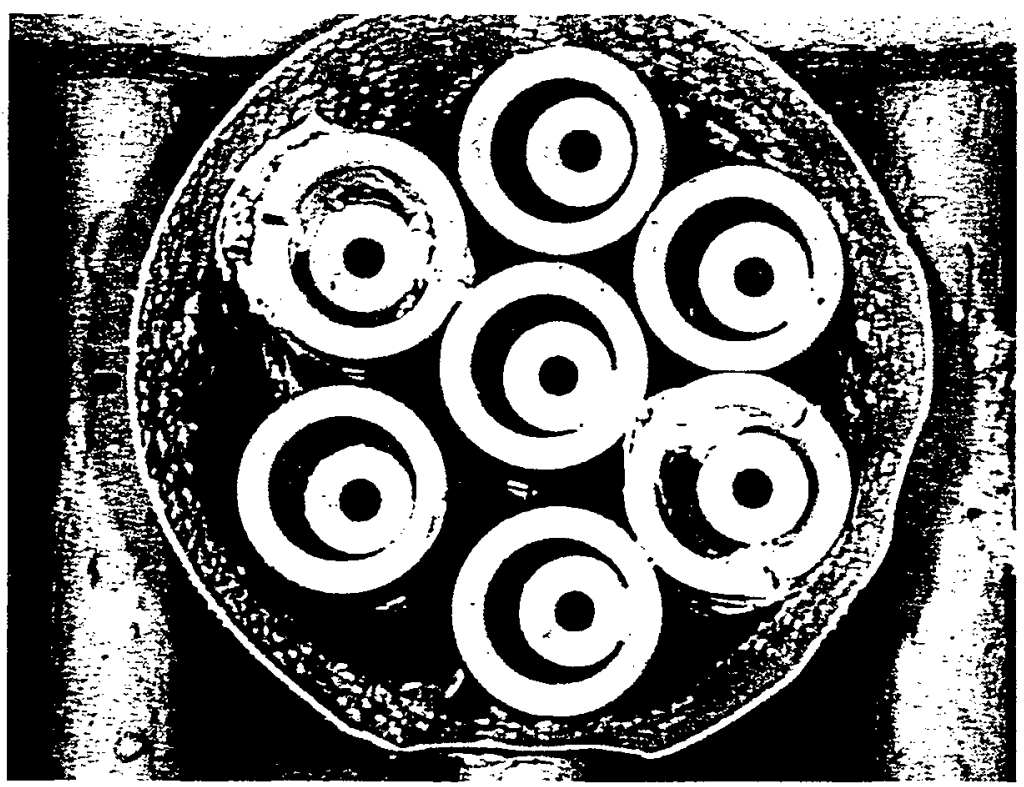


Figure A27. Moderate Fue1 Damage Canister Candidate/West Bay--Location 5056E.

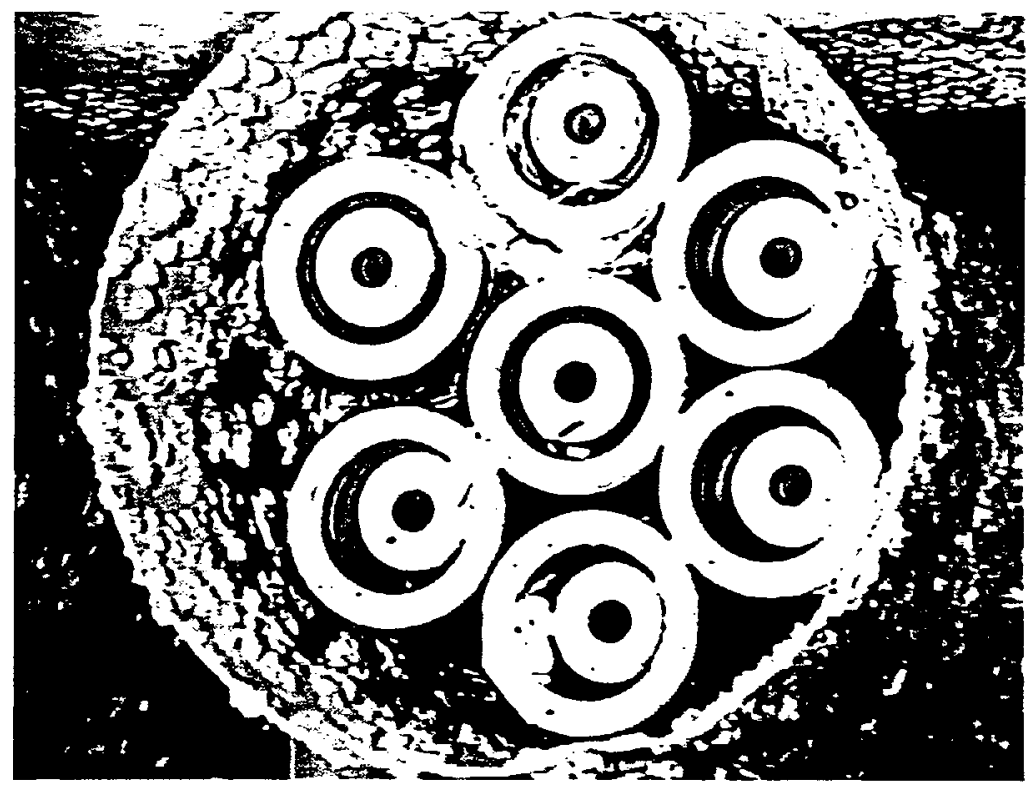


Figure A28. Moderate Fuel Damage Canister Candidate/West Bay--Location 5069E.

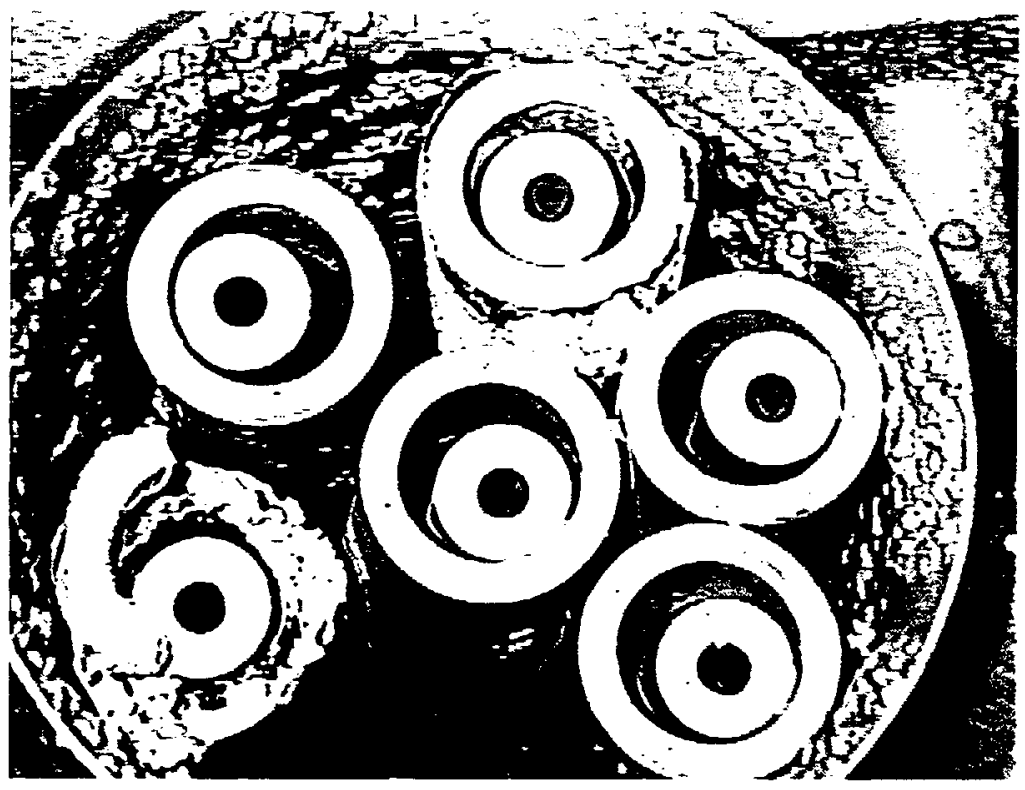


Figure A29. Moderate Fuel Damage Canister Candidate/West Bay--Location 6451E.

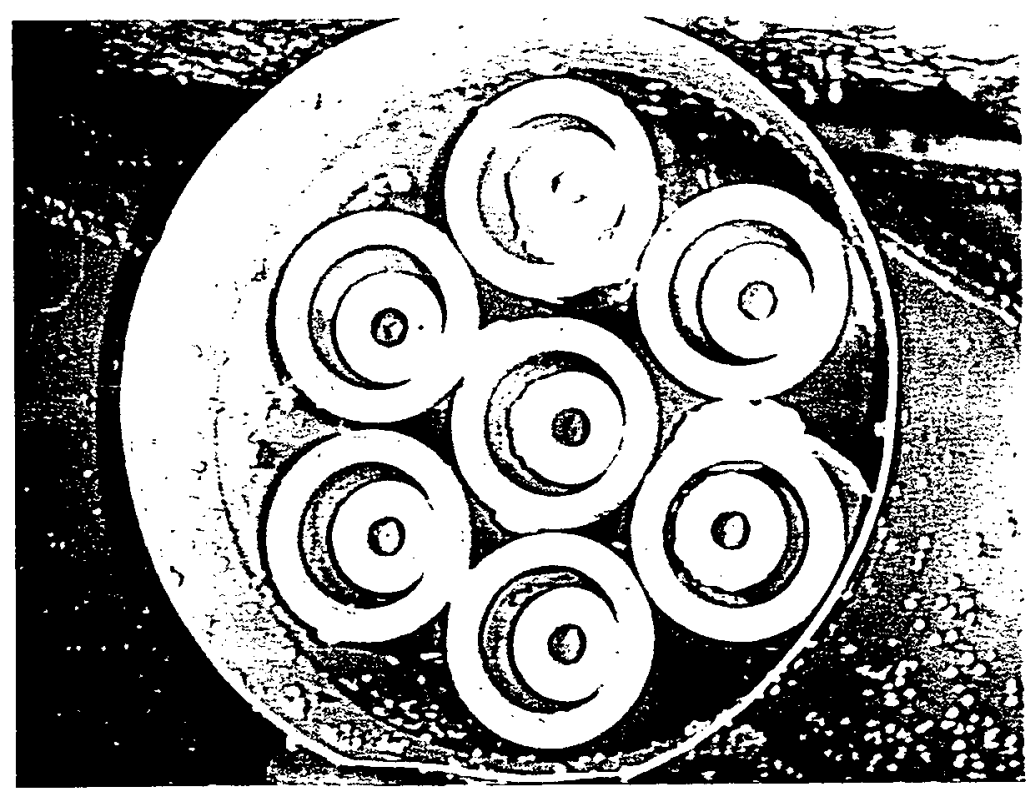


Figure A30. Moderate Fuel Damage Canister Candidate/West Bay--Location 6452E.

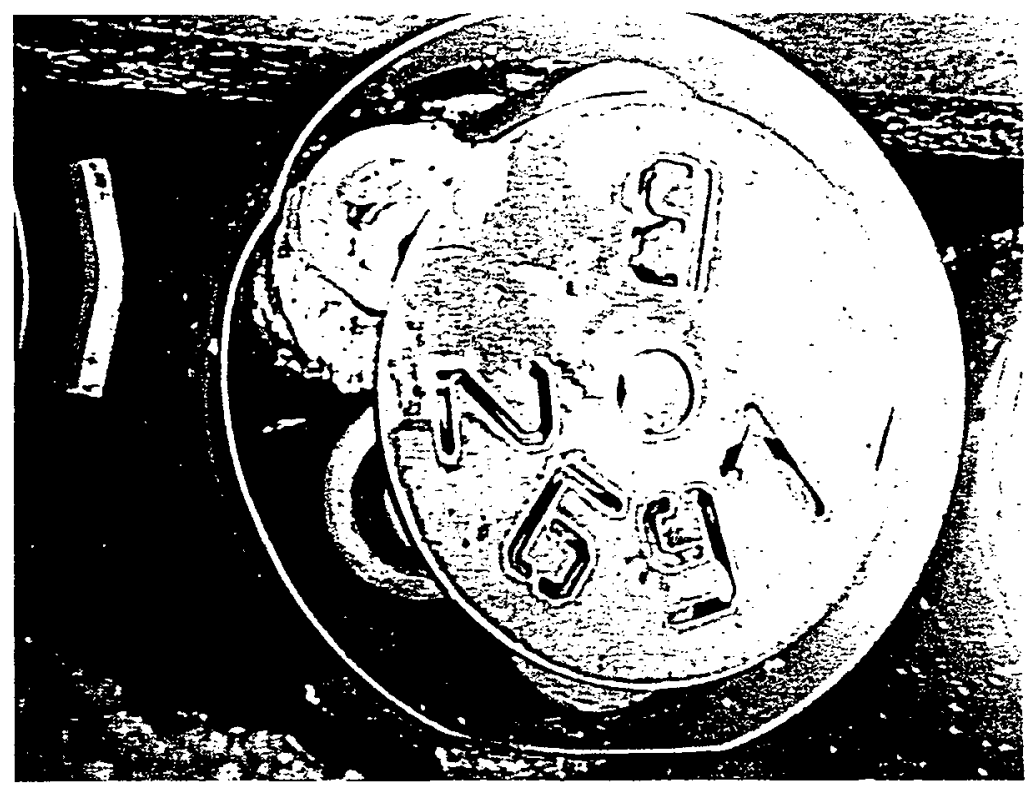


HNF-4016, Rev. 0

Figure A31. Moderate Fuel Damage Canister Candidate/West Bay--Location 6757W.

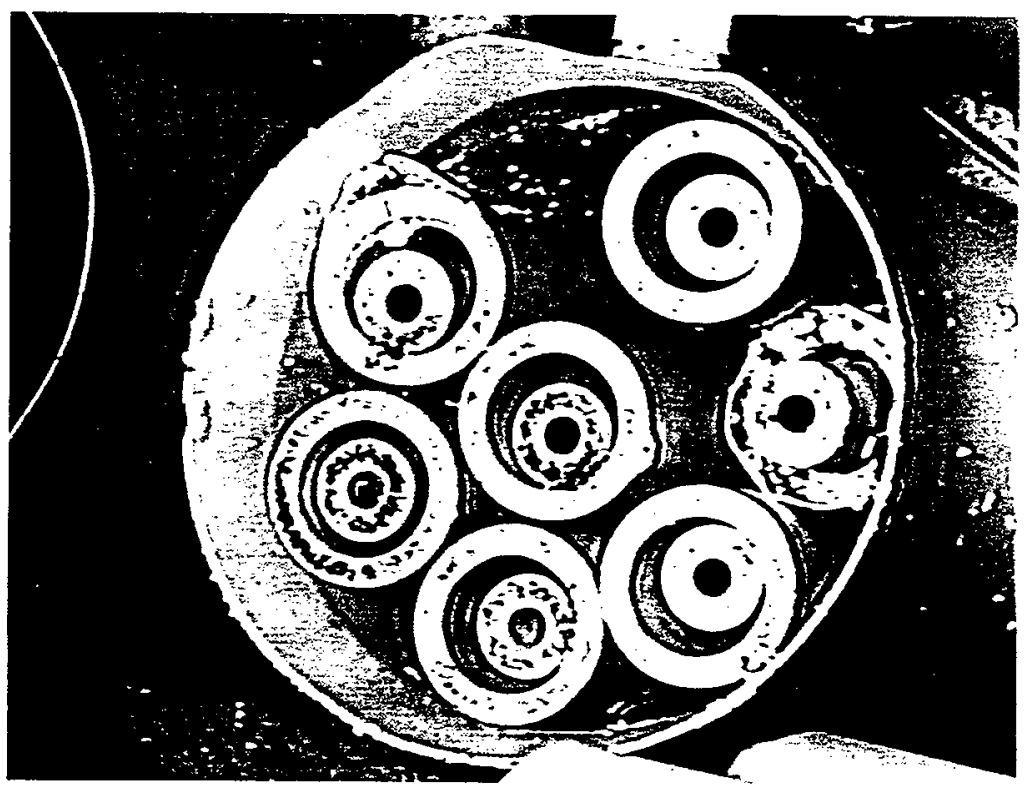


HNF-4016, Rev. 0

Figure A32. Moderate Fue1 Damage Canister Candidate/West Bay--Location 6760W.

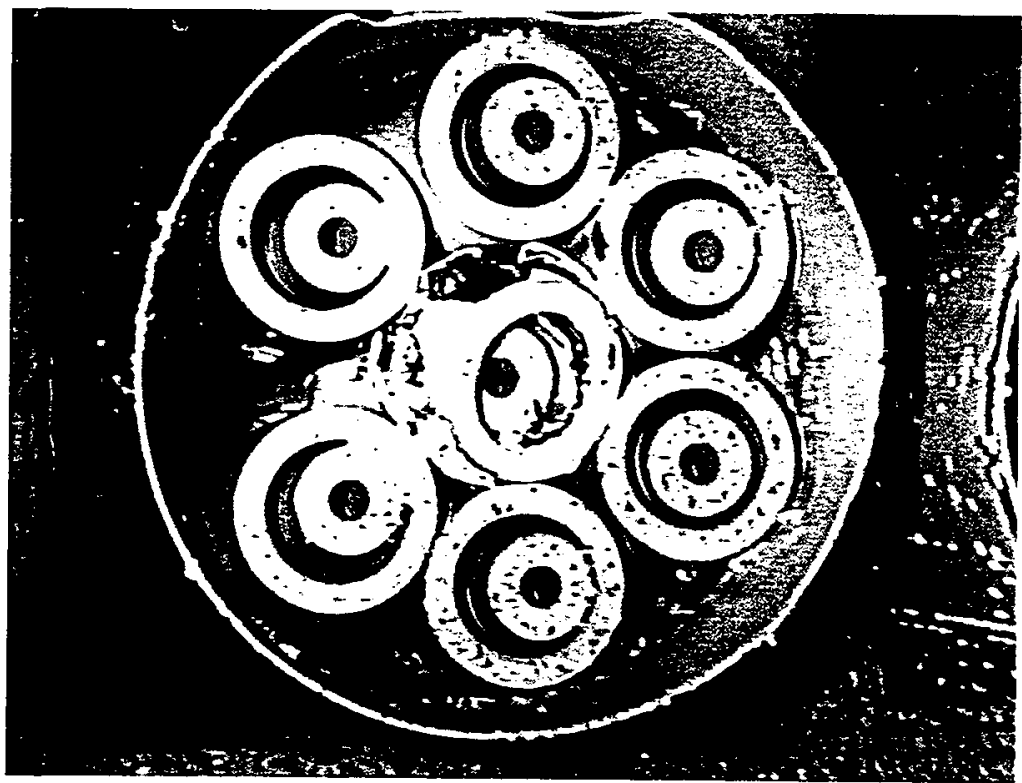


HNF-4016, Rev. 0

Figure A33. Between Barre]s/East Bay--Locations 1168 and 1267.

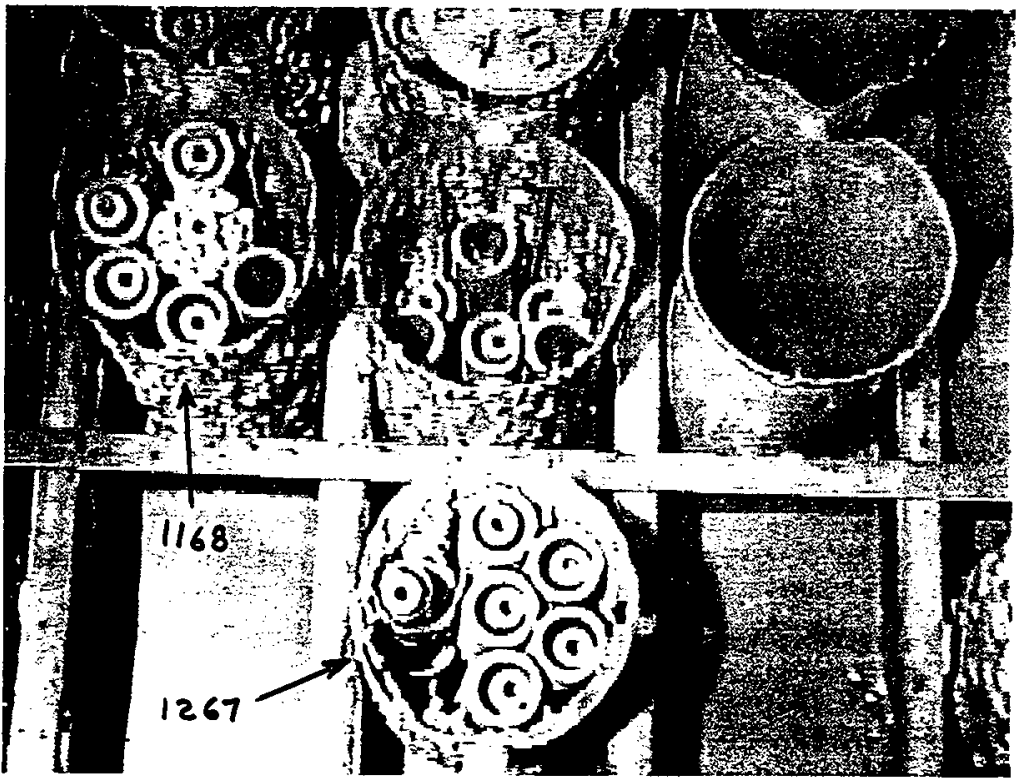


Figure A34. Between Barrels/East Bay--Locations 1234 and 1236.

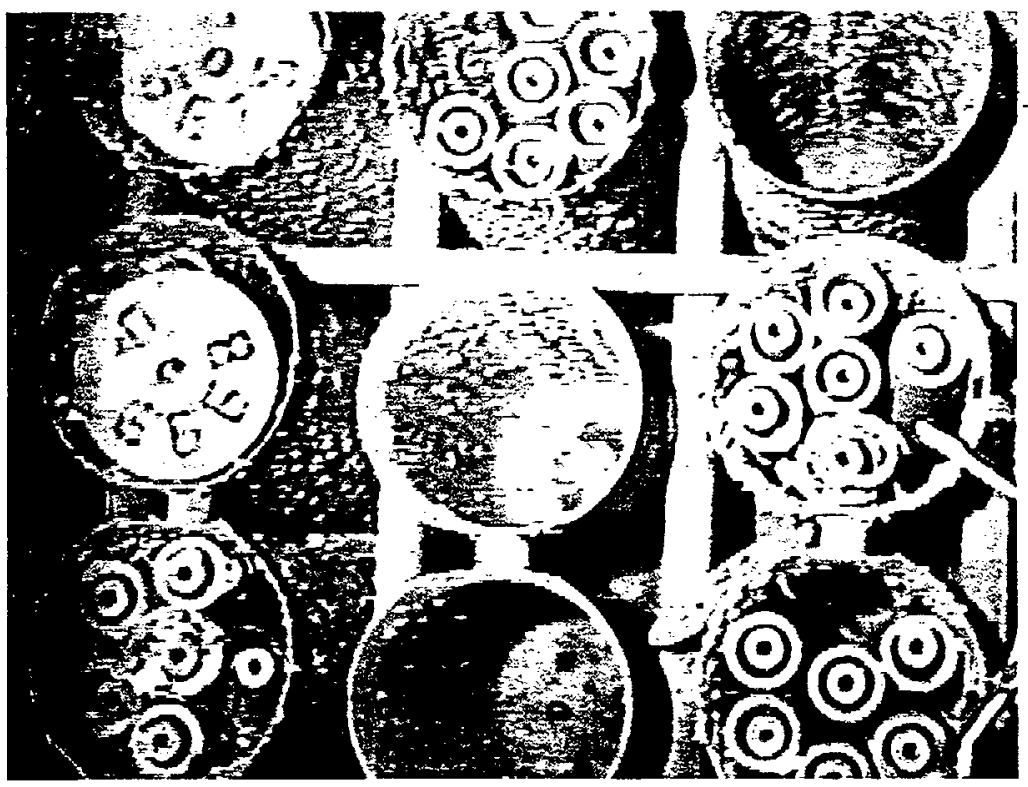


Figure A35. Between Barrels/Center Bay--Locations 2952 and 2953.

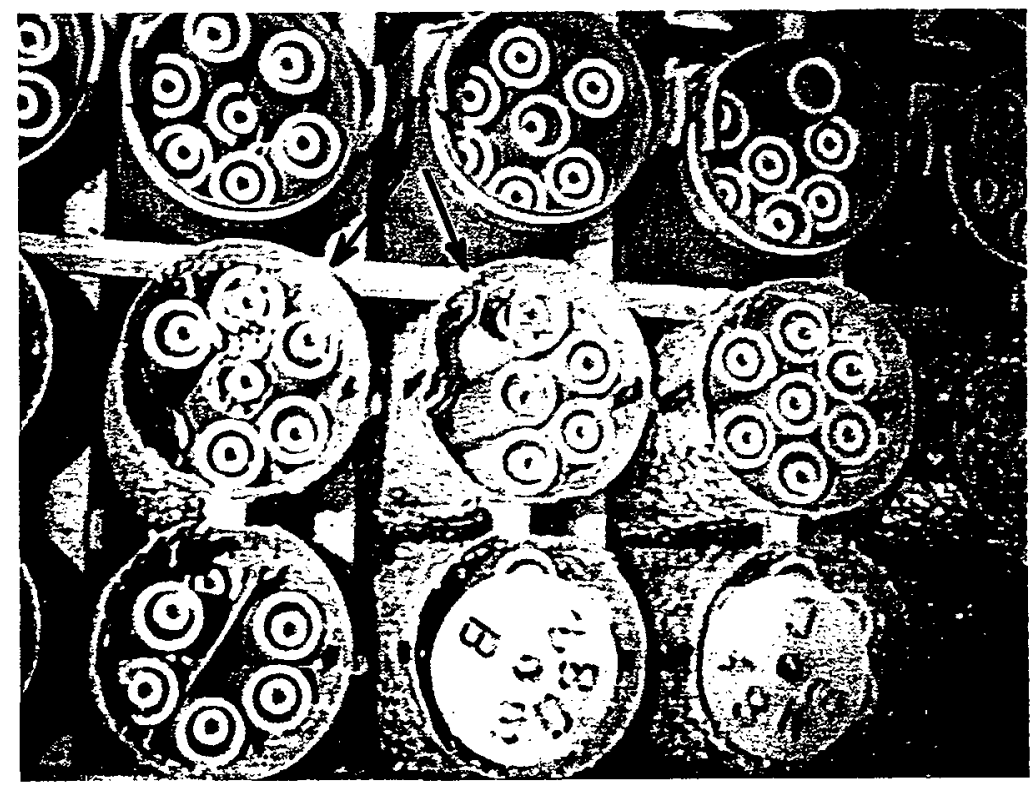


Figure A36. Between Barrels/Center Bay--Locations 2958 and 2960.

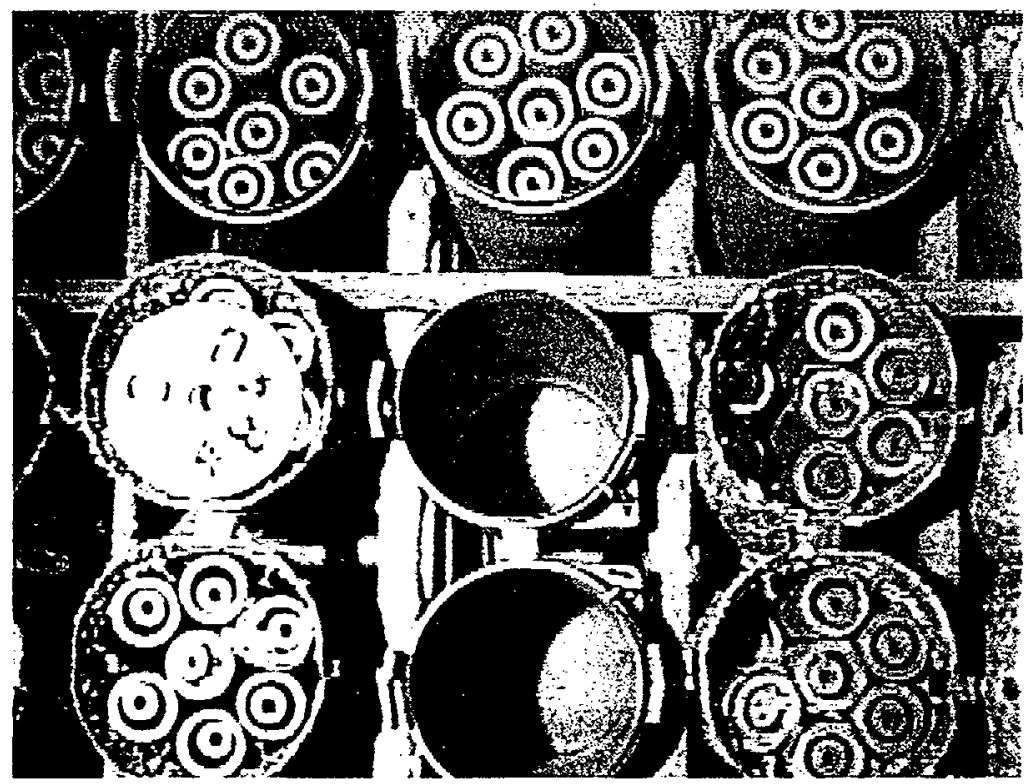


Figure A37. Between Barrels/Center Bay--Location 4573.

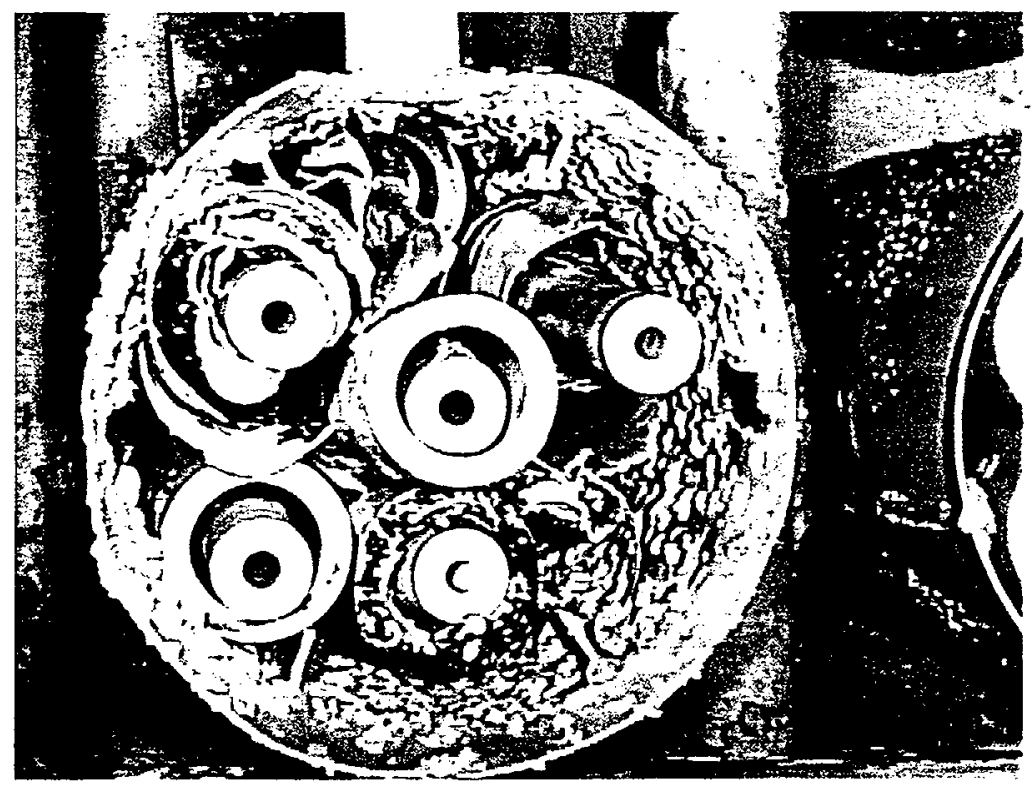


Figure A38. Between Barrels/West Bay--Location 5465.

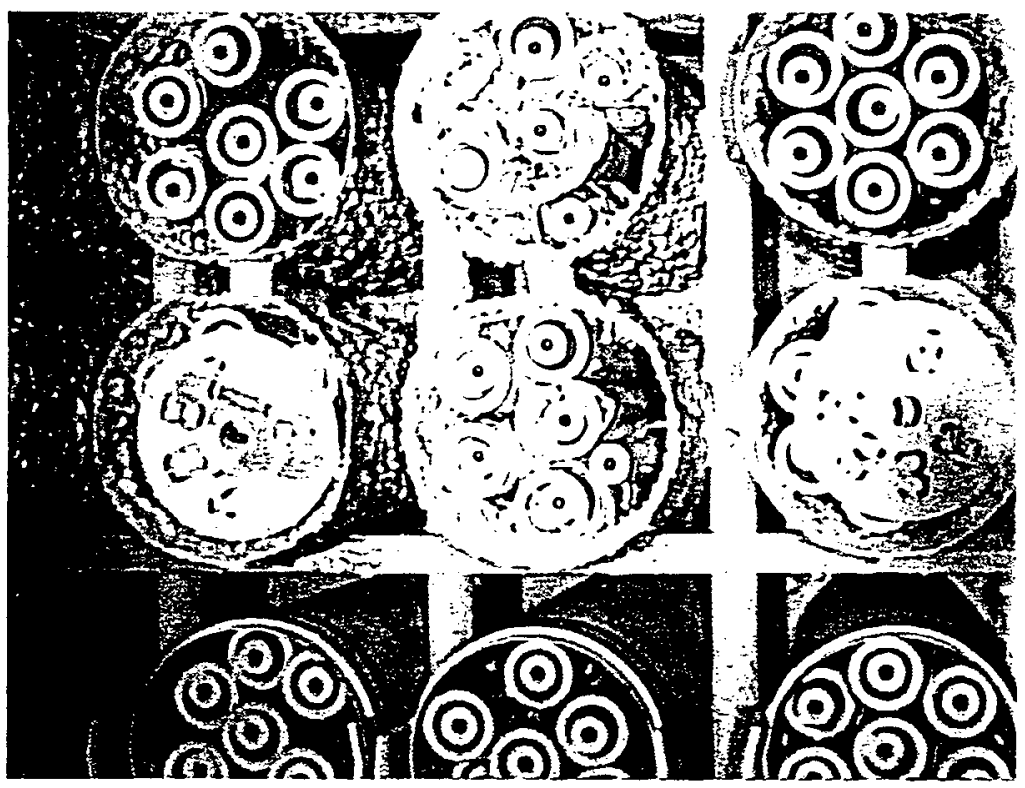


Figure A39. Between Barrels/West Bay--Locations 5445, 5446, and 5447.

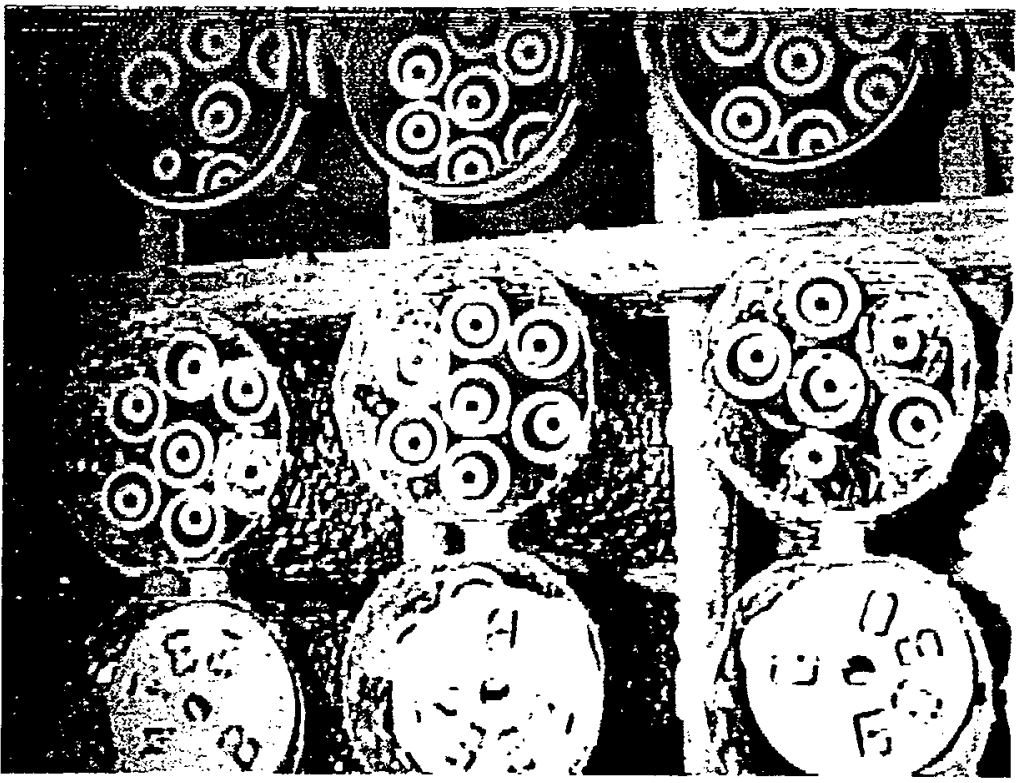


Figure A40. IXM Beads in Locations 6752, 6753, and 6754 .

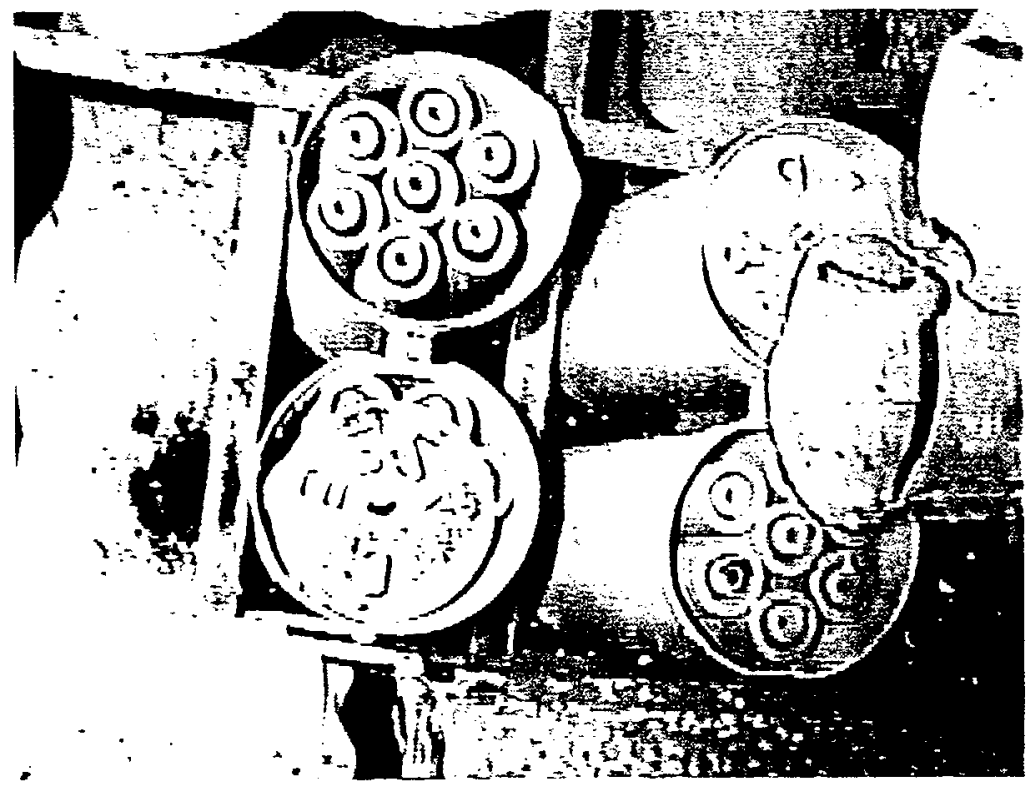


HNF-4016, Rev. 0

A P PENDIX B

REVIEW OF NEEDS FOR PCB ANALYSES FOR FUTURE $K$ BASIN SLUDGE 
HNF-4016, Rev. 0

This page intentionally left blank. 


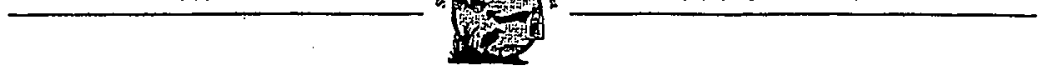

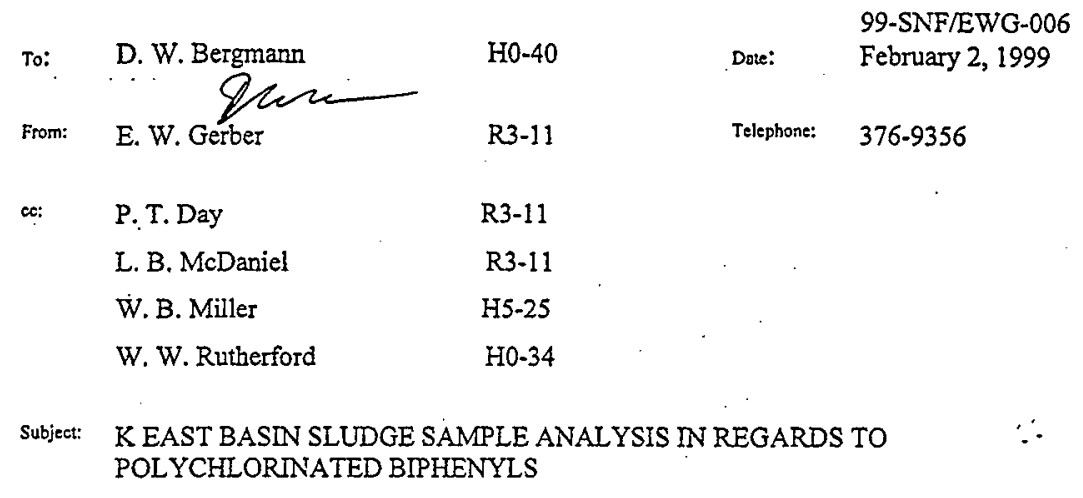

References: (1) Letter, A. J. Schmidt, PNL to R. P. Omberg, DESH " Evaluation of Polychlorinated Biphenyls (PCB) Data from K East Basin Sludge Samples," January 7, 1997

(2) R. B Baker, T. L .Welsh, B. J. Makenas, and K. L. Pearce, "Sampling and Analysis Plan for Sludge on the Floor and in the Pits of the $105 \cdot \mathrm{K}$ Basins," HINF-3556, Rev., dated November, 1998.

(3) B. J. Makenas and R. B. Baker, "Data Quality Objectives for K West and K East Basin Floor and from Other Basin Areas," HNF-2033, Rev 0, October 1998.

This letter documents the Spent Nuclear Fuel (SNF) Project approach for further characterization of Polychlorinated Biphenyls ( $\mathrm{PCBs}$ ) in the K East (KE) Basin sludge.

\section{Background}

Analyses of sludge samples collected from the $\mathrm{KE}$ Basin during past characterization efforts detected the presence of PCBs at low concentrations. This raised the issues of whether the sludge is regulated under the Toxic Substances Control Act (TSCA) and, if so, what the TSCA requirements are relative to the sludge. For the past year, the U.S. Environmental Protection Agency (EPA), the Department of Energy, Richland Operation Office (RL), and SNFP have had ongoing discussions to resolve these issues.

The lighest concentration of PCBs detected was approximately 140 parts per million on a settled solids basis (Reference 1). There is no information available to identify the source of the PCBs or the time period in which they were introduced into the sludge. Based on this, RL and SNFP have determined that the sludge meets the definition of a $\mathrm{PCB}$ remediation waste under the 
Page 2

February 2, 1999

TSCA Disposal Amendments of 1998 and is subject to TSCA disposal requirements. However, the primary risk associated with the sludge continues to be radionuclides. Therefore, $R L$ and SNFP intend to use the risk-based approach allowed by the TSCA Disposal Amendments to address the PCBs. EPA endorses the use of the risk-based approach for the sludge.

There are two basic components to the proposed risk-based approach. The most critical . component is a demonstration that, without any treatment, the total mass of PCBs in the sludge is so low that they do not present a risk to human health or the environment. The second component is a requirement to incorporate into the sludge treatment system a process or technology that removes or destroys PCBs. The selection of a process or technology can be based on general PCB guidance and literature. Process testing with actual or simulated K Basins sludge for the purpose of demonstrating that $\mathrm{PCBs}$ will be removed or destroyed will not be required. Furthermore, there will be no specific performance standards for sludge treatment relative to $\mathrm{PCBs}$, nor will there be a requirement to sample and analyze for PCBs after treatment.

\section{Future PCB Analysis}

Slucige samples are currently being collected from the floor and pits of the $\mathrm{KE}$ Basin to support development of the sludge treatment system. Most of the planned analyses will be performed on samples that represent a given area. In many cases, these area-specific samples will be composites of samples from two or more individual locations within that area. For example, samples from three locations on the floor of the basin will be composited into a single sample representing the $\mathrm{KE}$ Basin main floor sludge. There will be a total of seven area-specific samples for the $\mathrm{KE}$ Basin.

Because the proposed risk-based approach does not depend. on the specific performance of the sludge treatment system with respect to PCB removal or destruction, there is no significant value in knowing the range or variability of potential $\mathrm{PCB}$ concentrations in the areas of the basin. Therefore, $P C B$ analyses should not be performed on the area-specific samples. However, it is important to have information on the average concentration of $\mathrm{PCBs}$ in the sludge to support the demonstration that the PCBs present no threat to human health or the environment. Therefore, the SNFP approach to analyzing sludge samples for PCBs in the near-term is as follows:

1. Determine a baseline composite PCB concentration. This should be done by preparing and analyzing a sludge sample that is a composite of the sludge currently being collected from the KE Basin floor and pits. This baseline composite sample should be based, to the extent practicable, on the relative volumes of siudge located in the primary physical areas in the basin. The ratio of volumes from each sampling area should be similar to the ratios indicated 
Mr. D. W. Bergmann

99-SNF/EWG-006

Page 3

February 2, 1999

in the figure on page 71 of the current sampling analysis plan (SAP) (Reference 2), with the exception that the "Canister" and "Wash" sludge components should not be included. The individual area-specific composite samples (identified in Table 6 of Reference 2) should be used to prepare the baseline composite sample.

2. Incorporate the second sludge sampling campaign. A second sampling campaign is planned to provide samples of canister sludge as well as additional samples of floor sludge. If samples from the second campaign are available at the time the baseline composite is created, the material from the second campaign should also be considered in building the.:baseline composite sample.

3. Archive individual samples. The balance of material from the individual area-specific composite samples should be archived so that area-specific PCB analyses can be performed if necessary at a later date. If it is more efficient or technically appropriate to archive samples from the individual sampling locations rather than area-specific composite samples, this should be done. At the present time, area-specific composite samples and individual sludge samples should not be analyzed for PCBs.

\section{Management of Laboratory Wastes}

Waste streams generated by the laboratcities during general analysis or process testing of the sludge samples should be accumulated to the maximum volume practicable prior to designating the streams for disposal. Accumulation is prodent both to minimize waste disposal costs and ensure that analyses performed to assist waste designation are as representative as possible. The accumulated waste should be analyzed for PCBs. If any waste stream is regulated under TSCA, it should be disposed in accordance with the TSCA requirements for laboratory waste.

The data quality objectives (DQO) report (Reference 3) and SAP (Reference 2) for the current floor and pit slidige sampling in $\mathrm{K}$ Basins should be revised to reflect the direction provided here. The DQO and SAP being prepared for the second sludge sampling campaign should also incorporate this direction.

If you have any questions, please call me.

$\mathrm{bb}$ 


\section{DISTRIBUTION SHEET}

\begin{tabular}{|c|c|c|c|c|c|}
\hline \multirow{2}{*}{$\begin{array}{l}\text { To } \\
\text { Distribution }\end{array}$} & \multirow{2}{*}{\multicolumn{3}{|c|}{$\begin{array}{l}\text { From } \\
\text { SNF Characterization Project/ } \\
2 \text { F700 }\end{array}$}} & \multicolumn{2}{|l|}{ Page 1 of 2} \\
\hline & & & & \multicolumn{2}{|c|}{ Date February 1999} \\
\hline \multicolumn{4}{|c|}{ Project Title Work Order } & \multicolumn{2}{|c|}{ EDT No. 626201} \\
\hline \multicolumn{4}{|c|}{$\begin{array}{l}\text { Sampling and Analysis Plan for the Consolidated Sludge Samples } \\
\text { from the Canisters and Floor of the 105-K East Basin/HNF-4016, } \\
\text { Rev. 0 }\end{array}$} & \multicolumn{2}{|c|}{ ECN No. } \\
\hline \multicolumn{2}{|c|}{ Name } & $\begin{array}{l}\text { Text } \\
\text { With All } \\
\text { Attach. }\end{array}$ & Text Only & $\begin{array}{l}\text { Attach./ } \\
\text { Appendix } \\
\text { Only }\end{array}$ & $\begin{array}{c}\text { EDT/ECN } \\
\text { Only }\end{array}$ \\
\hline
\end{tabular}

Fluor Daniel Hanford, Inc.
E. W. Gerber
L. B. McDaniel
R. L. McCormack
N. H. Williams

$\begin{array}{ll}\text { R3-11 } & X \\ \text { R3-11 } & x \\ \text { R3-11 } & x \\ \text { R3-11 } & x\end{array}$

\section{B\&W Protec}

T. L. Welsh

Duke Engineering \& Services Hanford, Inc.

R. B. Baker (2)

D. W. Bergmann

K. H. Bergsman

A. E. Bridges

R. W. Brown

S. A. Chastain

S. L. Hecht

M. J. Horhota

D. P. Kimball

D. P. Maassen

P. J. MacFarlan

B. J. Makenas

K. R. Morris

A. L. Pitner

D. W. Smith

J. A. Swenson

C. A. Thompson

D. J. Trimble

SNF Project File

\section{Informatics}

J. M. Harvey

J. A. Serles

Lockheed Martin Services, Inc.

Central Files

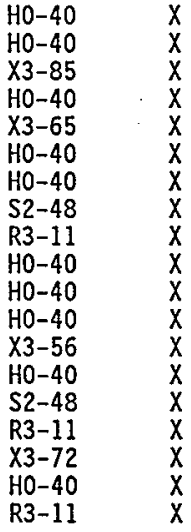

$\begin{array}{ll}H 0-34 & X \\ H 0-40 & X\end{array}$

B1 $-07 \quad X$.




\section{DISTRIBUTION SHEET}

\begin{tabular}{|c|c|c|c|c|c|}
\hline \multirow{2}{*}{$\begin{array}{l}\text { To } \\
\text { Distribution }\end{array}$} & \multirow{2}{*}{\multicolumn{3}{|c|}{$\begin{array}{l}\text { From } \\
\text { SNF Characterization Project/ } \\
2 \text { F700 }\end{array}$}} & \multicolumn{2}{|l|}{ Page 2 of 2} \\
\hline & & & & \multicolumn{2}{|c|}{ Date February 1999} \\
\hline \multicolumn{4}{|c|}{ Project Title/Work Order } & \multicolumn{2}{|c|}{ EDT No. 626201} \\
\hline \multicolumn{4}{|c|}{$\begin{array}{l}\text { Sampling and Analysis Plan for the Consolidated Sludge Samples } \\
\text { from the Canisters and Floor of the 105-K East Basin/HNF-4016, } \\
\text { Rev. } 0\end{array}$} & \multicolumn{2}{|l|}{ ECN No. } \\
\hline \multicolumn{2}{|c|}{ Name } & $\begin{array}{l}\text { Text } \\
\text { With All } \\
\text { Attach. }\end{array}$ & Text Only & $\begin{array}{l}\text { Attach./ } \\
\text { Appendix } \\
\text { Only }\end{array}$ & $\begin{array}{c}\text { EDT/ECN } \\
\text { Only }\end{array}$ \\
\hline
\end{tabular}

Numatec Hanford Corporation
D. B. Bechtold
D. A. Dodd
T. A. Flament
H. C. Miller
T6-07 $X$
T6-50
HO-34
H5-25
$\mathrm{HO}-34$
HO-34
C. A. Petersen
H7 -20

$$
\begin{aligned}
& X \\
& X
\end{aligned}
$$$$
\hat{X}
$$$$
\hat{X}
$$
W. W. Rutherford$$
\hat{x}
$$

Pacific Northwest National Laboratory
P. R. Bredt
C. H. Delegard
G. R. Golcar
A. J. Schmidt
K. L. Silvers

P7-25

P7-25

K6-24

$\mathrm{K} 2-12$

K9-08

$$
\begin{aligned}
& X \\
& X \\
& X \\
& X \\
& X
\end{aligned}
$$

U.S. Department of Energy, Richland Operations office
J. Shuen
S7-41
$x$

Waste Management Federal Services of Hanford, Inc.

F. H. Steen

T6-12

$x$

DOE/RL Reading Room

H2-53 X.

